San Jose State University

SJSU ScholarWorks

Master's Theses

Master's Theses and Graduate Research

1992

\title{
The Effect of diet on tissue levels and liver DNA adducts in rats as a result of exposure to 2-amino-3,8-dimethylimidazo [4,5-f] quinoxaline (MelQx)
}

Christopher Edward Frantz

San Jose State University

Follow this and additional works at: https://scholarworks.sjsu.edu/etd_theses

\section{Recommended Citation}

Frantz, Christopher Edward, "The Effect of diet on tissue levels and liver DNA adducts in rats as a result of exposure to 2-amino-3,8-dimethylimidazo [4,5-f] quinoxaline (MelQx)" (1992). Master's Theses. 314. DOI: https://doi.org/10.31979/etd.h44c-5m22

https://scholarworks.sjsu.edu/etd_theses/314

This Thesis is brought to you for free and open access by the Master's Theses and Graduate Research at SJSU ScholarWorks. It has been accepted for inclusion in Master's Theses by an authorized administrator of SJSU ScholarWorks. For more information, please contact scholarworks@sjsu.edu. 


\section{INFORMATION TO USERS}

This manuscript has been reproduced from the microfilm master. UMI films the text directly from the original or copy submitted. Thus, some thesis and dissertation copies are in typewriter face, while others may be from any type of computer printer.

The quality of this reproduction is dependent upon the quality of the copy submitted. Broken or indistinct print, colored or poor quality illustrations and photographs, print bleedthrough, substandard margins, and improper alignment can adversely affect reproduction.

In the unlikely event that the author did not send UMI a complete manuscript and there are missing pages, these will be noted. Also, if unauthorized copyright material had to be removed, a note will indicate the deletion.

Oversize materials (e.g., maps, drawings, charts) are reproduced by sectioning the original, beginning at the upper left-hand corner and continuing from left to right in equal sections with small overlaps. Each original is also photographed in one exposure and is included in reduced form at the back of the book.

Photographs included in the original manuscript have been reproduced xerographically in this copy. Higher quality $6^{\prime \prime} \times 9^{\prime \prime}$ black and white photographic prints are available for any photographs or illustrations appearing in this copy for an additional charge. Contact UMI directly to order.

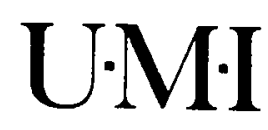

University Microfilms Internatıonal

A Bell \& Howell Information Company

300 North Zeeb Road. Ann Arbor. MI 48106-1346 USA

313:761.4700 800:521-0600 
Order Number 1348675

The effect of diet on tissue levels and liver DNA adducts in rats as a result of exposure to 2-amino-3,8dimethylimidazo[4,5-f]quinoxaline (MelQx)

Frantz, Christopher Edward, M.A.

San Jose State University, 1992 



\title{
The Effect of Diet on Tissue Levels and Liver DNA Adducts in Rats as a Result of Exposure to 2-Amino-3,8- Dimethylimidazo $[4,5-f]$ Quinoxaline (MelQx)
}

\author{
A Thesis \\ Presented to \\ The Faculty of the Department of Biology \\ San Jose State University
}

\author{
In Partial Fulfillment \\ of the Requirements for the Degree \\ Masters of Arts
}

By

Christopher Edward Frantz

May, 1992 
APPROVED FOR THE DEPARTMENT OF BIOLOGY
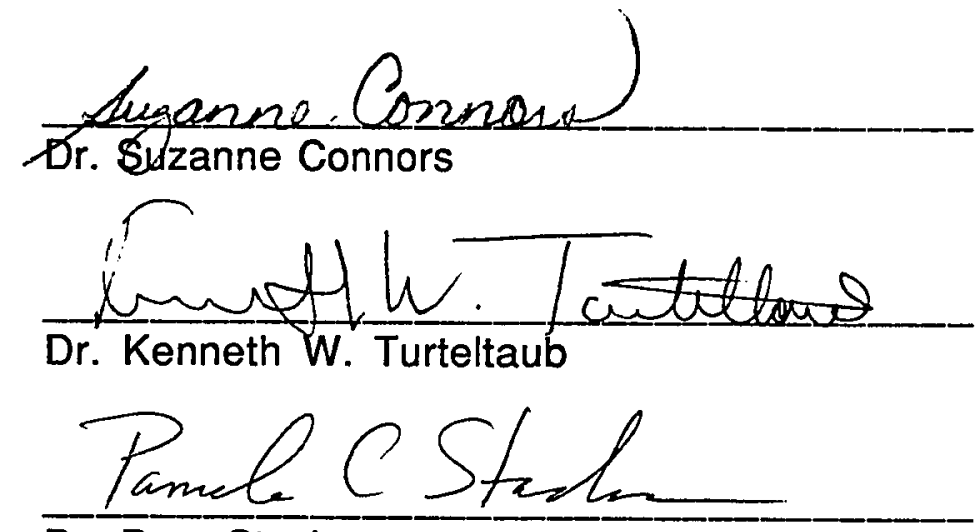

Dr. Pam Stacks

APPROVED FOR THE UNIVERSITY

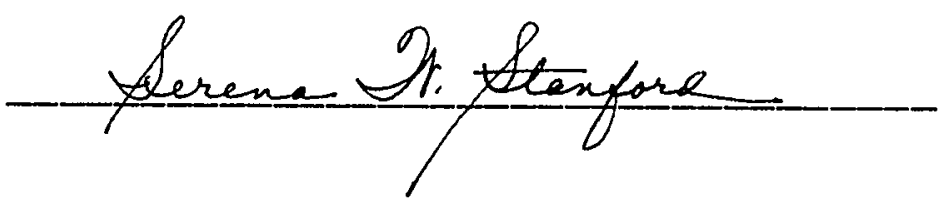




\begin{abstract}
The Effect of Diet on Tissue Levels and Liver DNA Adducts in Rats as a Result of Exposure to 2-Amino-3,8-Dimethylimidazo [4,5-f ] Quinoxaline (MelQx)

\author{
by Christopher Edward Frantz
}

2-amino-3,8-dimethylimidazo[4,5-f]quinoxaline (MelQx) is a heterocyclic amine found in cooked meats and has previously been shown to be highly mutagenic in the Ames/Salmonella test, causes cancer in laboratory animals at high doses, and forms DNA adducts in rats and mice. The influence of two diet matrices was examined using laboratory rodent chow and fried hamburger on tissue levels of MelQx and DNA adducts formed by MelQx in liver. Male Sprague Dawley rats were fed 46 or $111 \mathrm{ng} / \mathrm{kg} /$ day of $\left[2^{14} \mathrm{C}\right] \mathrm{MelQx}$ for up to 42 days in one of the two diets. The results demonstrate that the diet did not exert a significant influence on the levels of MelQx in the tissues. Furthermore diet had no influence on DNA adduct levels. In order to measure the extremely low levels of $[2-14 \mathrm{C}] \mathrm{MelQx}$ used in this study, a new tool in biological dosimetry, accelerator mass spectrometry (AMS) was used to determine the carbon-14 nuclei present in the tissues and DNA.
\end{abstract}




\section{ACKNOWLEDGEMENTS}

The author wishes to thank everyone who assisted and contributed to this thesis, and without whose help it would not have been possible. The graduate committe: Sue Connors, academic advisor at SJSU, Pam Stacks, at SJSU, and Ken Turteltaub, research advisor at LLNL. The scientists at Lawrence Livermore National Laboratory who have helped in countless ways, Julia Avila, Barry Bruckhorst, Mike Buonarti, Jim Felton, Ester Fultz, Gian Gross, Kurt Haack, Mark Knize, Ann Merck, Dan Moore, Michelle Roper, Nancy Shen, John Southton, Patrece Talley, John Vogel, and Becky Wu. All my friends and farnily who have supported me (literally and figuratively) throughout this endeavor. 


\section{CONTENTS}

INTRODUCTION

Carcinogens and the Diet 3

Effect of Diet on Carcinogens and Procarcinogens 4

Carcinogens as Components of Food 5

Carcinogens in Cooked Meats 6

Mutagenic Activity 8

Carcinogenicity $\quad 9$

Proposed Carcinogenic Mechanisms of the

Heterocyclic Amines 17

Metabolism 18

Metabolism and DNA adducts 20

Dose Response and DNA adduct Formation 21

DNA Adducts as Biomarkers 23

Accelerator Mass Spectrometry (AMS) 23

AMS of Heterocyclic Amines $\quad 24$

MATERIALS AND METHODS 26

MelQx Radiopurification and Purity 26

Diet Preparation and Analysis $\quad 27$

Animals 30

Tissue Removal and Storage 32

Sample Preparation for AMS 32

Accelerator Mass Spectrometry 36

Carbon Analysis of Diets, Tissues, and DNA 39

Modern 39

Quantitation of MelQx 39

Statistical Analysis 39 
Analysis of Diets 40

Carbon Analysis of Diets, Tissues, and DNA 42

Animal Doses 43

Animal Weights $\quad 45$

Tissue Levels $\quad 48$

DNA Binding $\quad 59$

Statistical Analysis $\quad 63$

$\begin{array}{ll}\text { DISCUSSION } & 65\end{array}$

Feasibility Study $\quad 65$

Diet Comparison Experiment 70

Dose Comparison to Human Exposure $\quad 71$

Extrapolation of Dose-Response $\quad 72$

Examination of DNA Dose-Response $\quad 82$

Absence of Diet Effect $\quad 84$

Dose Effect $\quad 85$

Tissue Distribution and $[2-14 \mathrm{C}] \mathrm{MelQx}$ Steady-State Levels $\quad 86$

DNA Adducts $\quad 88$

Risk Assesment 90

$\begin{array}{ll}\text { Summary } & 91\end{array}$

$\begin{array}{ll}\text { REFERENCES } & 92\end{array}$

\section{APPENDICIES}

Appendix One, DNA Isolation 99

Appendix Two, Calculation of [2-14C]MelQx Levels 103

Appendix Three, HPLC Protocol 106

Appendix Four, Ames Test Protocol 112

Appendix Five, Analysis of Variance Statisitical

Data Results and Plots 


\section{LIST OF TABLES}

Table 1: Mutagens identified in heated foods

Table 2: Mutagenicity of the food pyrolysis heterocyclic amines in the Ames/Salmonella assay.

Table 3: Tumor incidence in mice.

Table 4: Tumor incicence in rats.

Table 5: Planned dosing regime for feasibility experiment. 30

Table 6: Planned dosing regime for diet comparison experiment.

Table 7: Analysis of raw hamburger diet from feasibility experiment.

Table 8: Analysis of diets from diet comparison experiment. 40

Table 9: Carbon content (\%) of rat tissues and diets.

Table 10: Average doses of feasibility experiment.

Table 11: Average doses of diet comparison experiment.

Table 12: Percent change in rat body weight over time.

Table 13: Average tissue levels of [2-14C[MelQx in rats in feasibility experiment.

Table 14: Average tissue levels of $\left[2-{ }^{14} \mathrm{C}[\mathrm{MelQx}\right.$ in rats in diet comparison experiment.

Table 15: Average tissue levels of [2-14C[MelQx from the adjusted chow feeding study. 
Table 16: Average rat liver DNA levels of [2-14C[MelQx.

Table 17: DNA levels of [2-14C[MelQx from the adjusted chow feeding study. 


\section{LIST OF FIGURES}

Figure 1: Structure of the food pyrolysis heterocyclic amines.

Figure 2: Schematic of xenobiotic metabolism.

Figure 3: Schematic of cancer progression.

Figure 4: Disposable cryogenic separation transfer manifold.

Figure 5: Schematic of accelerator mass spectrometer.

Figure 6: Growth rate comparison.

Figure 7: Level of MelQx in rat blood throughout a 42 day exposure period.

Figure 8: Level of MelQx in rat heart throughout a 42 day exposure period.

Figure 9: Level of MelQx in rat kidney throughout a 42 day exposure period.

Figure 10: Level of MelQx in rat liver throughout a 42 day exposure period.

Figure 11: Level of MelQx in rat lung throughout a 42 day exposure period.

Figure 12: Level of MelQx in rat pancreas throughout a 42 day exposure period.

Figure 13: Level of MelQx in rat spleen throughout a 42 day exposure period. 
Figure 14: Level of MelQx in rat thymus throughout a 42 day exposure period.

Figure 15: Level of MelQx in rat liver DNA throughout a 42 day exposure period.

Figure 16: MelQx adducts in rat liver DNA. 62

Figure 17: Tissue levels of MelQx in rat tissues from the feasibility experiment.

Figure 18: Comparison of actual response from dose in hamburger and predicted response from dose in chow in rat blood.

Figure 19: Comparison of actual response from dose in hamburger and predicted response from dose in chow in rat heart tissue.

Figure 20: Comparison of actual response from dose in hamburger and predicted response from dose in chow in rat kidney tissue.

Figure 21: Comparison of actual response from dose in hamburger and predicted response from dose in chow in rat liver tissue.

Figure 22: Comparison of actual response from dose in hamburger and predicted response from dose in chow in rat lung tissue.

Figure 23: Comparison of actual response from dose in hamburger and predicted response from dose in chow in rat pancreas tissue.

Figure 24: Comparison of actual response from dose in hamburger and predicted response from dose in chow in rat spleen tissue. 
Figure 25: Comparison of actual response from dose in hamburger and predicted response from dose in chow in rat thymus tissue.

Figure 26: Dose response in rat kidney tissue.

Figure 27: Dose response in rat liver tissue. 86

Figure 28: Liver DNA adduct versus dose of MelQx. 89 


\section{INTRODUCTION}

A cancer is defined as a mass of tissue cells that has an unlimited potential for growth, serves no useful function in the body, and robs the host of nutrients necessary for survival (1). What causes cancer continues to be the focus of great scientific effort. A dietary link to cancer has been established. It is estimated that an average of $35 \%$ of all human cancers may be caused by dietary factors $(2,3)$. In this thesis I will describe research on a class of chemicals (known as heterocyclic amines) produced by a pyrolytic reaction during the cooking of meat. Specifically the focus will be on 2-amino-3,8,-dimethylimidazo[4,5-f]quinoxaline (MelQx, also referred to as $8-\mathrm{MelQx}$ ) and the effect of diet on both the tissue distribution and DNA adducts formed at levels equivalent to human dietary exposure.

MelQx is a heterocyclic amine found in cooked meats, and has been shown to be highly mutagenic in the Ames/Salmonella assay and mammalian cell lines $(4,5)$. Many of the food borne heterocyclic amines, including MelQx, have been shown to cause cancer in laboratory animals $(6,7)$ and form DNA adducts in rats and mice (8). The results of this research project will be important for determining the relationship between animal exposure and human exposure to the heterocyclic amines. The data will also be useful in increasing the accuracy of the risk determination for exposure to heterocyclic amines at realistic exposure levels, that is, those levels commonly found in cooked meats. 
Diet has also been linked to cancer by epidemiological studies. The most well known of these studies is on the change in dietary behavior of populations of Japanese ancestry who migrated to the United States. As their diet changed from traditional Japanese food to the American diet, the incidence of stomach cancer declined, and the number of cases of breast cancer increased to equal the average in the United States (9).

Specific dietary conditions have been generated in rat carcinogen experiments to alter tumor incidence. For example the occurrence of spontaneous mammary tumors is reduced by calorie restriction. The incidence of sarcomas and skin cancers induced by benzo[a]pyrene is lower in rats fed a restricted caloric diet than in rats fed ad libitum. (9). 


\section{CARCINOGENS AND THE DIET}

\section{Contents of the Diet}

The diet can affect the formation of carcinogens in the body by several mechanisms (2). The diet can contain substrates for the formation of a carcinogen, for example, nitrites, nitrates, or secondary amines. In these cases the carcinogenic affect is related to the amount of substrate ingested. Certain bile acid metabolites such as deoxycholic acid and lithocholic acids act as substrates by causing an increase in cholesterol and bile acid metabolites found in the feces.

Other factors can affect the bioavailability of ingested compounds such as fluid and food intake, which in turn can affect intestinal transit time, altering the time a compound is available for absorption. Food high in fat, and to a lesser degree food high in protein, delay gastric emptying and therefore delay the rate of passage of ingested compounds through the small intestine, where large absorptive areas exist (10).

Fiber in the diet can affect tumor incidence by adsorbing compounds and preventing interaction with macromolecules. Adsorption of chemicals may occur onto dietary fiber components. An example of this is the drug digoxin, which has been shown to have its absorption delayed if taken with bran fiber (10). In addition cancer causing food components such as fats can increase the absorption of compounds. Highly lipid soluble compounds, such as the antifungal drug griseofulvin, are more readily absorbed when taken with a meal containing fat (10). 


\section{Effect of Diet on Carcinogens and Procarcinogens}

Diet affects the transport, activation, and deactivation of carcinogens in the digestive system (2). The diet can cause induction (i.e. increase in the amount of enzymes) or inhibition of enzymes, that affect carcinogen metabolism. In laboratory rodents, carcinogens that require activation by enzymes (procarcinogens), or that can be metabolized to an inactive detoxified excretable metabolite, may have their carcinogenic potential greatly reduced by compounds found in the diet that induce or inhibit the relevant enzymes in the target tissue (2). This role has been suggested for the indoles found in Brassica and other vegetables. Vitamin $E$ has been shown to protect laboratory animals against carcinogens by functioning as an antioxidant. The mechanism of antioxidant activity occurs when vitamin $E$ traps free radicals and peroxides, thus reducing the potential for cell damage by highly oxidizing compounds (2). 


\section{Carcinogens as Components of Food}

Carcinogens and procarcinogens can be found in the human diet. For example, carcinogens may be contained in natural food stuffs, may be produced during the cooking of food, or can be produced in stored food by microorganisms. It is the ingestion of carcinogens and procarcinogens over which a person can exercise the most control. The first step in controlling exposure to dietary carcinogens is knowing where they are found or what causes their formation. Carcinogens and procarcinogens, such as cycasin, found in the cycad nut, pyrrolizidine alkaloids found in Senecio and other plant genera, and safrole from sassafras, occur naturally in many human foodstuffs $(2,11)$. A carcinogen does not have to be an original component of the food for it to be ingested. Aflatoxin $B_{1}$, for example, a product of the fungus Aspergillus flavus, is a carcinogenic precursor that commonly contaminates peanuts and other staple carbohydrate foods stored in hot humid climates, and is suspected as a contributing factor in the development liver cancer in some tropical countries (2). 


\section{CARCINOGENS IN COOKED MEATS}

\section{Carcinogen Formation in the Cooking Process}

The presence of carcinogens in roasted foods was first described by Widmark in 1939 (12). He described the occurrence of tumors in mice when an extract of roast horse meat, roast coffee, or browned butter was painted onto the skin of mice. The pyrolysis that occurs during the cooking of protein-rich foods causes mutagenic and carcinogenic compounds to be formed. Cooking over an open flame or charring meat results in the formation of polycyclic aromatic hydrocarbons (PAHs) such as benzo[a]pyrene, a potent carcinogen, which is the most prevalent PAH found in charred foods or foods exposed to smoke. The PAHs were originally thought to be the sole source of mutagenic activity in cooked meat, however the high mutagenic activities found in the charred meats could not be accounted for by the low benzo[a]pyrene levels measured (11). This led to the search for the additional compounds that caused the mutagenic activity. The formation of mutagenic compounds during the cooking of meat was described by Sugimura et al. in 1977 (11). These investigators demonstrated that when fish was broiled to a "well done" state (whole fish on a steel net over flame or charcoal), high mutagenic activity could be detected with the Ames/Salmonella assay. 
The charred surface of heat processed foods was also demonstrated to be mutagenic by Nagao et al. in 1977 (13). Independently Vithayathil et al. reported a consistent rate of mutagenesis in the Ames/Salmonella test that was higher than normal when beef extract was a component of the bacterial growth media and liver enzyme activation was part of the test system (14). The phenomenon was discovered when, during an extended battery of tests on some organic compounds, a small difference was noted between two different control groups of bacteria. Further investigation concluded that the beef extract component of the nutrient broth contained one or more mutagens and that the mutagens required activation by microsomal enzymes in the bacterial test system in order to become mutagenic. Soon after, Commoner demonstrated that mutagenic activity resulted from cooking beef at household temperatures, approximately $200^{\circ} \mathrm{C}$ (15). Since then 17 heterocyclic amines have been isolated and identified as potent mutagens using a combination of chromatographic techniques in conjunction with the Ames/Salmonella mutagenicity test $(4,5)$. In addition to being mutagenic, all of the heterocyclic amines formed during the cooking of muscle meats are carcinogenic in long term animal experiments (16).

Molecular structures of the heterocyclic amines were determined by variety of analytical methods, nuclear magnetic resonance, high performance and gas chromatography, ultra-violet spectrometry, and mass spectrometry (4). Mutagenic activities range over orders of magnitude in the Ames test $(4,5,17,18)$. Carcinogenic activity has been seen in mice, rats, and non-human primates $(3,4,5,7,16,17,18,19,20)$. (See Table 1 and Figure 1) 


\section{Mutagenic Activity}

The Ames/Salmonella and mammalian cell culture test systems are used to determine mutagenicities through reverse mutation assays and His $D$ gene assays (21). The heterocyclic amines are mutagenic with most of the commonly used bacterial . strains in the Ames/Salmonella test (Table 2). For example, in control plates with no test compound added there will be a small number of spontaneous revertants. The addition of a compound that is not mutagenic, water for example, would not increase the number of revertants above the level seen in control plates. The addition of a positive control, such as 2-acetylaminofluorene, a known mutagenic substance, causes a large number of revertant colonies to form (21).

Cigarette smoke is a useful reference to relate the mutagenic activities of other compounds too. Inhaling cigarette smoke is generally regarded as greatly increasing one's risk of cancer. The mutagenic activity of smoke can be compared to the mutagenic activity of dietary heterocyclic amines. Cigarette smoke causes between 89 to 293 bacterial revertants (positive results of mutagenic activity) per $\mathrm{mg}$ of smoke condensate in bacterial strain TA1538. Cigarettes contain between $10.3-10.7 \mathrm{mg}$ smoke condensate per cigarette (22). One hamburger has a mutagenic activity between 100 to 10,000 revertants/gram, depending on how it was cooked. So a 100 gram hamburger will cause 10,000 to $1,000,000$ revertants. If an average cigarette causes 200 revertants per gram smoke condensate and contains $10 \mathrm{mg}$, it will cause 2000 revertants /cigarette, or 40,000 per pack. Thus one cooked hamburger contains the mutagenic activity of between 0.25 and 250 packs of cigarettes. All of the heterocyclic amines that have been identified to date are mutagenic when tested by the Ames/Salmonella assay (5). 


\section{Carcinogenicity}

Carcinogenicity, the potential for a compound to cause cancer, is usually determined by a battery of animal tests. Chemicals that cause one or more of four responses in animals are classified as carcinogens. The responses are: a) presence of tumor types not seen in controls, b) an increase in the incidence of tumor types occurring in controls, c) the development of tumors earlier than in controls, and d) an increased multiplicity of tumors (23). The results of some of the work published to date on heterocyclic amines produced by pyrolysis is summarized in Tables 3 and 4 . The effect of differing doses of MelQx on the formation of DNA adducts in rats has also been examined (8). It is important to note that the human doses are low. The doses given to all the animals used for the cancer studies were between one to five orders of magnitude greater than human exposure on a per weight basis. 
TABLE $1 \mathrm{a}$

Mutagens identified in heated foods.

Abbreviation Chemical name

MW Composition Abs

$(\max )$

$(\mathrm{nm})$

\begin{tabular}{|c|c|c|c|c|}
\hline Phe-P-1 & 2-Amino-5-phenylpyridine & 170 & $\mathrm{C}_{11} \mathrm{H}_{10} \mathrm{~N}_{2}$ & 268 \\
\hline $\mathrm{AaC}$ & 2-Amino-9H-pyrido[2,3-b]indole & 183 & $\mathrm{C}_{11} \mathrm{HgN}_{3}$ & 336 \\
\hline Glu-P-2 & 2-Aminodipyrido[1,2-a:3',2'-d]imidazole & 184 & $\mathrm{C}_{10} \mathrm{H}_{8} \mathrm{~N}_{4}$ & 265 \\
\hline Trp-P-2 & 3-Amino-1-methyl-5H-pyridole $[4,3-b]$ indole & 197 & $\mathrm{C}_{12} \mathrm{H}_{11} \mathrm{~N}_{3}$ & 264 \\
\hline MeAaC & 2-Amino-3-methyl-9H-pyridole $[2,3,-b]$ indole & 197 & $\mathrm{C}_{12} \mathrm{H}_{11} \mathrm{~N}_{3}$ & 343 \\
\hline $\mathbf{Q}$ & 2-Amino-3-methyl imidazo[4,5-f]quinoline & 198 & $\mathrm{C}_{11} \mathrm{H}_{10} \mathrm{~N}_{4}$ & 264 \\
\hline $10 x$ & 2-Amino-3-methyl imidazo[4,5,f]quinoxaline & 199 & $\mathrm{C}_{11} \mathrm{H}_{13} \mathrm{~N}_{3}$ & 274 \\
\hline Trp-P-1 & 3-Amino-1,4-dimethyl-5H-pyridole $[4,3,-b]$ indole & 211 & $\mathrm{C}_{13} \mathrm{H}_{13} \mathrm{~N}_{3}$ & 264 \\
\hline 4-MelQ & 2-Amino-3,4,-dimethyl-imidazole[4,5-f]quinoline & 212 & $\mathrm{C}_{12} \mathrm{H}_{12} \mathrm{~N}_{4}$ & 265 \\
\hline 4-MelQx & $\begin{array}{l}\text { 2-Amino-3,4,-dimethyl-imidazole }[4,5-f] \\
\text { quinoxaline }\end{array}$ & 213 & $\mathrm{C}_{11} \mathrm{H}_{11} \mathrm{~N}_{5}$ & 274 \\
\hline $8-M e \mid Q x$ & $\begin{array}{l}\text { 2-Amino-3,8,-dimethyl-imidazole }[4,5-f] \\
\text { quinoxaline }\end{array}$ & 213 & $\mathrm{C}_{11} \mathrm{H}_{11} \mathrm{~N}_{5}$ & 274 \\
\hline PhIP & 2-Amino-1-methyl-6-phenylimidazo[4,5-b]pyridine & 224 & $\mathrm{C}_{13} \mathrm{H}_{12} \mathrm{~N}_{4}$ & 315 \\
\hline 4,8-DiMeIQx & $\begin{array}{l}\text { 2-Amino-3,4,8-trimethyl-imidazo }[4,5-f] \\
\text { quinoxaline }\end{array}$ & 227 & $\mathrm{C}_{12} \mathrm{H}_{13} \mathrm{~N}_{5}$ & 274 \\
\hline
\end{tabular}

$a(18)$ 


\section{TABLE 2}

\section{Mutagenicity of the Food Pyrolysis Heterocyclic Amines in the Ames/Salmonella Assay}

\begin{tabular}{|c|c|c|c|c|}
\hline Compound & $\begin{array}{l}\text { Bacterial Strain } \\
\text { TA98 } \\
\text { (revertants/ } \mu \mathrm{g} \text { ) }\end{array}$ & $\begin{array}{l}\text { Bacterial Strain } \\
\text { TA1538 } \\
\text { (revertants } / \mu \mathrm{g} \text { ) }\end{array}$ & $\begin{array}{l}\text { Bacterial Strain } \\
\text { TA100 } \\
\text { (revertants / } / \mu \mathrm{g} \text { ) }\end{array}$ & Ref. \\
\hline Trp-P-1 & 39,000 & (n. & 1700 & 18 \\
\hline Trp-P-2 & $89,000-104,000$ & 47,000 & 1800 & 17,18 \\
\hline Glu-P-2 & 1900 & $\ldots$ & 12000 & 18 \\
\hline $\mathrm{AaC}$ & 300 & . & 20 & 18 \\
\hline $\mathrm{MeAaC}$ & 200 & . & 120 & 18 \\
\hline $\mathbb{Q}$ & $118,000-433,000$ & 94,000 & 7000 & $5,17,18$ \\
\hline 4-MeIQ & $253,000 \quad-660,000$ & $\ldots$ & 30,000 & 5,18 \\
\hline 8-MelQX & $37,500-145,000$ & 99,300 & 14,000 & 5,18 \\
\hline PhIP & 2000 & ............ & & 5 \\
\hline
\end{tabular}


<smiles>Nc1ccc(-c2ccccc2)cn1</smiles><smiles>Nc1ccc2c(n1)[nH]c1ccccc12</smiles><smiles>Nc1ccc2nc3ccccn3c2n1</smiles>

Glu-P-2<smiles>Cc1cc2c(nc1N)[nH]c1ccccc12</smiles>

MOAOC<smiles>Cn1c(N)nc2c3nccnc3ccc21</smiles><smiles>Cc1nc(N)cc2[nH]c3ccccc3c12</smiles>

Trp-p-2<smiles>Cn1c(N)nc2c3cccnc3ccc21</smiles>

10<smiles>Cc1c(N)nc(C)c2c1[nH]c1ccccc12</smiles>

Trp-p-1<smiles>Cc1cc2ncccc2c2nc(N)n(C)c12</smiles><smiles>Cc1cnc2c(ccc3c2nc(N)n3C)c1[N+](=O)[O-]</smiles><smiles>Cc1cc2nccnc2c2nc(N)n(C)c12</smiles><smiles>Cn1c(N)nc2ncc(-c3ccccc3)cc21</smiles><smiles>Cc1cnc2c(=O)cc(C)c3c(nc(N)n3C)c2n1</smiles>

FIGURE 1. Structures of the Food Pyrolysis Heterocyclic Amines (18). 
The heterocyclic amines tested for carcinogenicity, Trp-P-1, Trp-P-2, Glu-P-2, AaC, MeAaC, IQ, 4-MelQ, 8-MelQx, and PhIP have all caused cancer when given to rodents in high dose quantities $(0.02 \%-0.08 \%$ of total diet) $(16,19,24)$. A dietary level of $0.01 \%$ is equivalent to a 100 parts per million ( $\mathrm{ppm}$ ) exposure and the heterocyclic amines are found in cooked meats at much lower levels, that is parts per billion (ppb).

The following tables show the carcinogenicity and tumor sites in mice (Table 3 ) and rats (Table 4) fed various concentrations of the heterocyclic amines in the diet. A number of different relationships exist, including a variation in tumor sites, sex related differences in tumor occurrence, and even contradictory results as in the case of liver tumor formation in mice as a result of exposure to IQ. The heterocyclic amines, like many other chemical compounds, show a difference in tumor induction between the sexes. This effect is thought to be largely related to differences in the endocrine system, which in turn, affects the levels of metabolizing enzymes, which ultimately exert an effect on tumor growth (23). 
TABLE 3

Tumor Incidence in Mice.

\begin{tabular}{|c|c|c|c|c|c|}
\hline Compound & Tumor Site & Dose ( $\%$ of Diet) & Sex & $\begin{array}{l}\text { Incidence } \\
(\%)\end{array}$ & References \\
\hline \multirow[t]{2}{*}{ Trp-P-1 } & Liver & $0.02 \%$ & $M$ & $21 \%$ & 19 \\
\hline & & & $F$ & $62 \%$ & \\
\hline \multirow[t]{2}{*}{ Trp-P-2 } & Liver & $0.02 \%$ & $M$ & $16 \%$ & 19 \\
\hline & & & $F$ & $92 \%$ & $\therefore$ \\
\hline \multirow[t]{4}{*}{ Glu-P-1 } & Liver & $0.05 \%$ & $M$ & $12 \%$ & 19 \\
\hline & & & $\mathrm{F}$ & $97 \%$ & \\
\hline & Blood vessel & $0.05 \%$ & $M$ & $88 \%$ & \\
\hline & & & $\mathrm{F}$ & $82 \%$ & \\
\hline \multirow[t]{4}{*}{ Glu-P-2 } & Liver & $0.05 \%$ & $M$ & $27 \%$ & 19 \\
\hline & & & $F$ & $100 \%$ & \\
\hline & Blood vessel & $0.05 \%$ & $M$ & $73 \%$ & \\
\hline & & & $F$ & $56 \%$ & \\
\hline \multirow[t]{4}{*}{$\mathrm{AaC}$} & Liver & $0.08 \%$ & $M$ & $39 \%$ & 19 \\
\hline & & & $F$ & $97 \%$ & \\
\hline & Blood vessel & $0.08 \%$ & $\mathbf{M}$ & $53 \%$ & \\
\hline & & & $F$ & $18 \%$ & \\
\hline \multirow[t]{4}{*}{ MeAaC } & Liver & $0.08 \%$ & $M$ & $57 \%$ & 19 \\
\hline & & & $F$ & $85 \%$ & \\
\hline & Blood vessel & $0.08 \%$ & $M$ & $95 \%$ & \\
\hline & & & $F$ & $85 \%$ & \\
\hline \multirow[t]{4}{*}{ Q } & Liver & $0.03 \%$ & $M$ & $41 \%$ & 19 \\
\hline & & & $\mathbf{F}$ & $27 \%$ & \\
\hline & Liver & $0.03 \%$ & $M$ & $41 \%$ & 18 \\
\hline & & & $F$ & $75 \%$ & \\
\hline \multirow[t]{2}{*}{ 4-MeIQ } & Liver & $0.04 \%$ & $M$ & $16 \%$ & 5 \\
\hline & & & $F$ & $71 \%$ & \\
\hline \multirow[t]{4}{*}{ 8-MelQx } & Liver & $0.06 \%$ & $M$ & $43 \%$ & 7 \\
\hline & & & $F$ & $91 \%$ & \\
\hline & Lung & $0.06 \%$ & $M$ & $43 \%$ & \\
\hline & & & $F$ & $43 \%$ & \\
\hline \multirow[t]{2}{*}{ PhIP } & Lymphoma & $0.04 \%$ & $M$ & $31 \%$ & 17 \\
\hline & & & $F$ & $68 \%$ & \\
\hline
\end{tabular}


TABLE 4

Tumor Incidence in Rats

\begin{tabular}{|c|c|c|c|c|c|}
\hline Compound & Tumor Site & Dose (\% of diet) & Sex & Incidence $(\%)$ & References \\
\hline \multirow[t]{2}{*}{ Trp-P-1 } & Liver & $0.015 \%$ & $M$ & $75 \%$ & 19 \\
\hline & & $0.02 \%$ & $\mathrm{~F}$ & $93 \%$ & \\
\hline \multirow[t]{2}{*}{ Trp-P-2 } & Liver & $0.02 \%$ & $M$ & $8 \%$ & 18 \\
\hline & Liver & $0.05 \%$ & $\begin{array}{l}F \\
M\end{array}$ & $\begin{array}{l}13 \% \\
83 \%\end{array}$ & 19 \\
\hline \multirow{7}{*}{ Glu-P-1 } & Livo & ס & $\mathrm{F}$ & $57 \%$ & \\
\hline & $\begin{array}{l}\text { Small } \\
\text { Intestine }\end{array}$ & $0.05 \%$ & $\begin{array}{l}M \\
F\end{array}$ & $\begin{array}{l}62 \% \\
24 \%\end{array}$ & \\
\hline & Large & $0.05 \%$ & $M$ & $45 \%$ & \\
\hline & Intestine & & $F$ & $17 \%$ & \\
\hline & Zymbal gland & $0.05 \%$ & M & $43 \%$ & \\
\hline & & & $\mathrm{F}$ & $43 \%$ & \\
\hline & Clitoral gland & $0.05 \%$ & $\mathbf{F}$ & $12 \%$ & \\
\hline \multirow[t]{8}{*}{ Glu-P-2 } & Liver & $0.05 \%$ & $\begin{array}{l}M \\
F\end{array}$ & $\begin{array}{l}26 \% \\
5 \%\end{array}$ & 19 \\
\hline & Small & $0.05 \%$ & $M$ & $33 \%$ & \\
\hline & Intestine & & $\mathbf{F}$ & $19 \%$ & \\
\hline & & & & $14 \%$ & \\
\hline & $\begin{array}{l}\text { Large } \\
\text { Intestine }\end{array}$ & $0.05 \%$ & $\begin{array}{l}M \\
F\end{array}$ & $19 \%$ & \\
\hline & Zymbal gland & $0.05 \%$ & M & $2 \%$ & \\
\hline & & & $\mathrm{F}$ & $17 \%$ & \\
\hline & Clitoral gland & $0.05 \%$ & $\mathrm{~F}$ & $26 \%$ & \\
\hline \multirow[t]{11}{*}{ Q } & Liver & $0.03 \%$ & $M$ & $68 \%$ & 3 \\
\hline & Large & $0.03 \%$ & $\begin{array}{l}F \\
M\end{array}$ & $\begin{array}{l}45 \% \\
63 \%\end{array}$ & \\
\hline & Intestine & & $F$ & $23 \%$ & \\
\hline & $\begin{array}{l}\text { Small } \\
\text { Intestine }\end{array}$ & $0.03 \%$ & $\begin{array}{l}M \\
F\end{array}$ & $\begin{array}{l}30 \% \\
3 \%\end{array}$ & \\
\hline & Zymbal gland & $0.03 \%$ & $\mathbf{M}$ & $90 \%$ & \\
\hline & & & $\mathbf{F}$ & $68 \%$ & \\
\hline & Skin & $0.03 \%$ & $\mathbf{M}$ & $43 \%$ & \\
\hline & & & $\mathbf{F}$ & $8 \%$ & \\
\hline & Oral cavity & $0.03 \%$ & $M$ & $5 \%$ & \\
\hline & & & $\mathrm{F}$ & $3 \%$ & \\
\hline & Clitoral gland & $0.03 \%$ & $\mathrm{~F}$ & $50 \%$ & \\
\hline
\end{tabular}


TABLE 4

continued

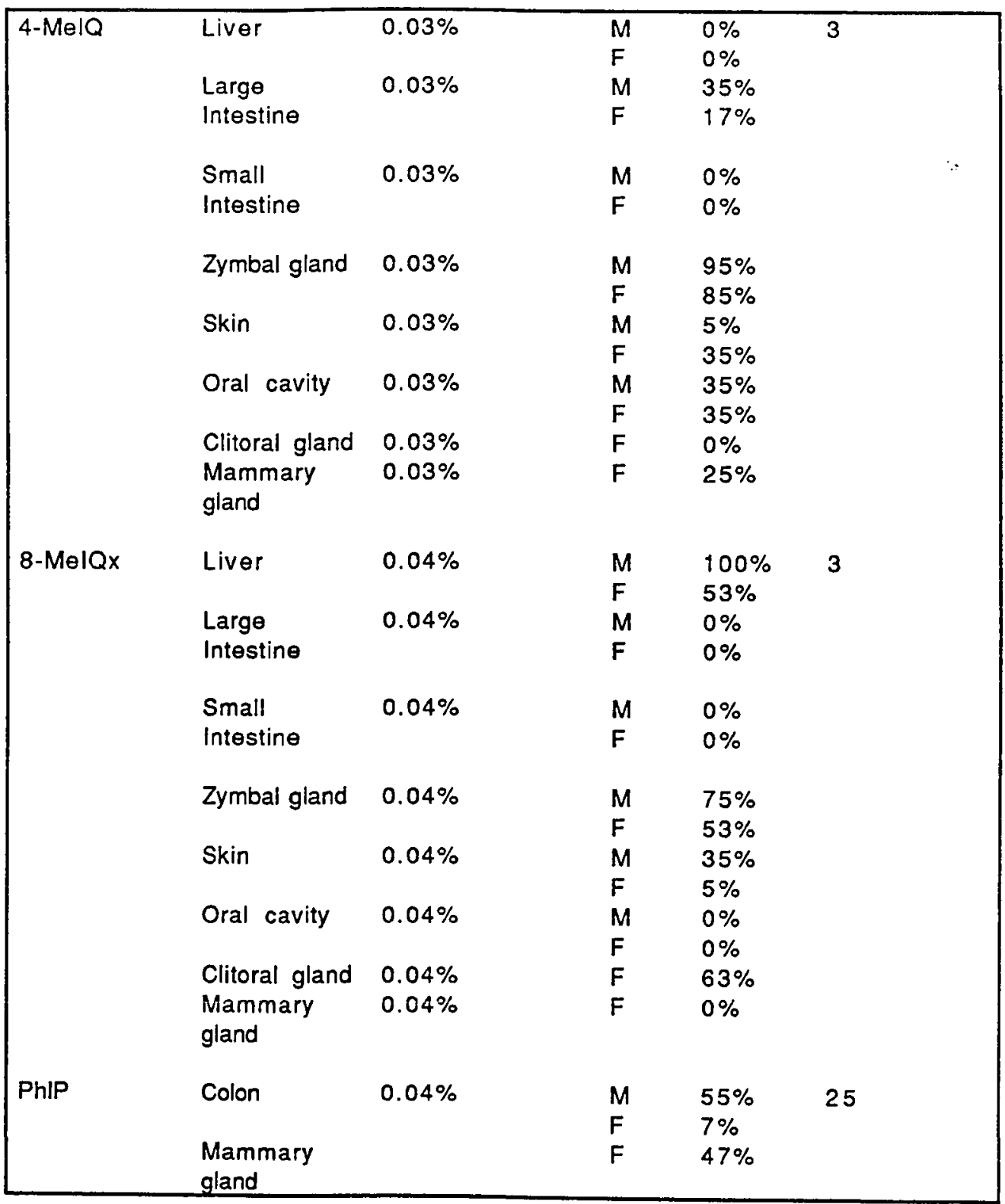




\section{Proposed Carcinogenic Mechanisms of the Heterocyclic Amines}

Carcinogens that form reactive electrophilic species bind covalently to nucleophilic centers in cells. The nucleophilic center of primary interest is DNA. The reaction between an electrophilic compound and DNA is either an $\mathrm{Sn}^{1}$ or an $\mathrm{Sn}^{2}$ addition of the electrophile to DNA. In the case of an $\mathrm{Sn}^{1}$ addition, the reaction kinetics are unimolecular, i.e. the concentration of the electrophile is rate determining. In the case of an $\mathrm{Sn}^{2}$ addition, the rate is bimolecular, i.e. the reaction rate is determined by both the concentration of the electrophile and the nucleophile $(26,27)$. 


\section{Metabolism}

Metabolism, also known as biotransformation, is the process by which absorbed xenobiotics are made more water soluble and hence excretable by the body. Xenobiotics that are absorbed are generally lipophilic and thus easily absorbed. If these compounds are not metabolized, they are not readily excreted. The role of metabolism is to transform a compound so that the body can easily excrete it. Enzymes catalyze these types of reactions, and the actual enzyme that transforms the chemical depends on the chemical structure of the xenobiotic. One effect of metabolism is that a compound may be transformed from a harmless form into a toxic, mutagenic, or carcinogenic form. This metabolism can occur in one or two phases. (Figure 2)

\section{XENOBIOTIC METABOLISM}

PHASE I

XENOBIOTIC

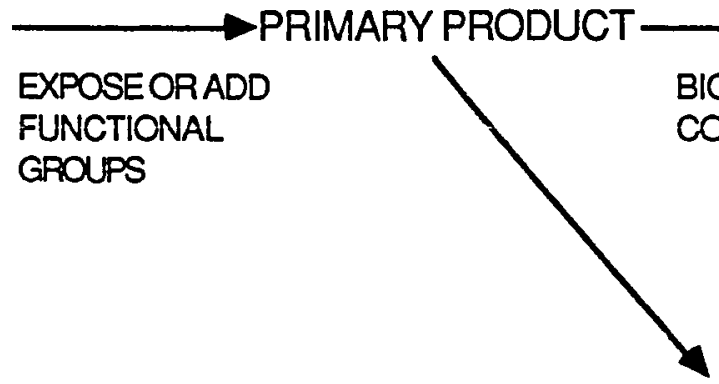

\section{PHASE 11}

SECONDARY PRODUCT

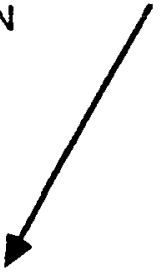

EXCRETION

FIGURE 2. Schematic of xenobiotic metabolism. (23) 
It is through metabolism of the heterocyclic amines that a DNA reactive form of the chemical is created. It is these transformed heterocyclic amines that bind to DNA, and are thought to cause tumor formation. The process by which the heterocyclic amines are thought to cause tumors is depicted in Figure 3.

\section{CHEMICAL CARCINOGENESIS}

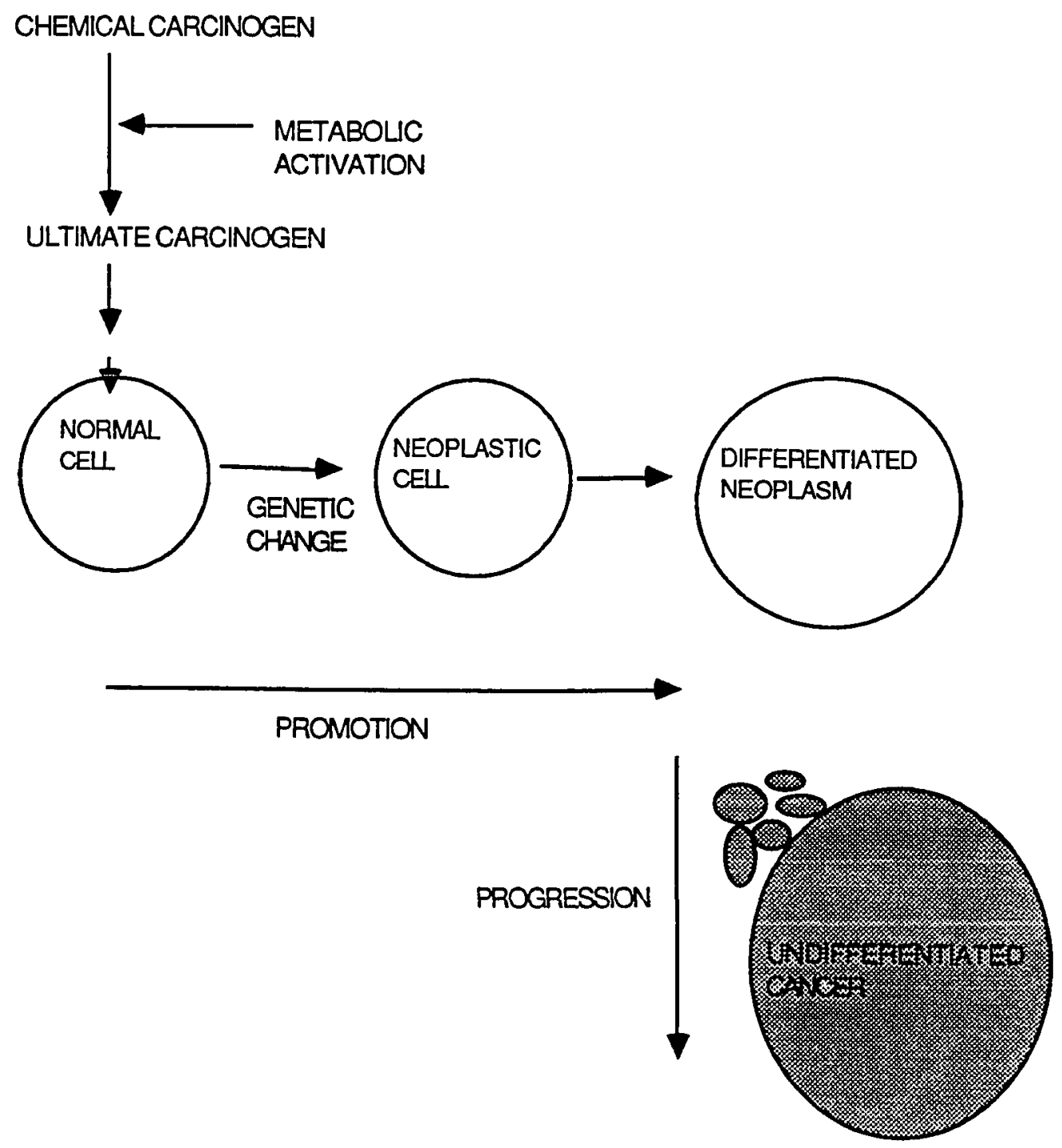

FIGURE 3. Schematic of Cancer Progression (23). 


\section{Metabolism and DNA Adducts}

The proposed mechanism of heterocyclic amine binding to DNA involves at least two metabolic steps. The first step is cytochrome P-450 mediated $\mathrm{N}$-hydroxylation $(28,29)$ followed by sulfonation or acetylation to an electrophilic and potentially DNA reactive species $(30,31)$. This reactive species probably contains a good leaving group which results in an electrophilic structure that can bind to DNA bases. It is through this interaction that a covalent bond forms, which results in damage to the DNA. If not repaired correctly, the DNA damage can lead to a viable cell with cancer causing potential.

Metabolism has been shown to be a significant factor in transforming MelQx into a DNA reactive species (28). Metabolism of MelQx involves metabolic transformation via the P450l family of isozymes, followed by conjugation via $\mathrm{N}: \mathrm{O}$-acetyltransferases (28). Turteltaub et al postulated that the ultimate DNA reactive species is a nitrenium ion (28). This was demonstrated by dosing mice with azido-MelQx and comparing the adducts formed by this compound to the adducts formed by dosing mice with MelQx. The adduct types were found to be similar which is why the formation of a nitrenium ion was postulated. The studies were done in groups of mice that had increased levels of various P450 isozymes as a result of injection with enzyme inducing compounds. The mice were injected with either phenobarbital (PB), Aroclor 1254, beta-napthoflavone (BNF) or corn oil via an intraperitoneal injection. The mice were then given MelQx by oral gavage and euthanized 24 hours later. The livers were removed, the DNA was isolated and the DNA adducts were measured using the 32P-Postlabeling method. Four adduct types were found in each DNA sample (28). The actual position of the adduct on DNA is still under investigation. The adduct levels were quantified and compared to animals that were given MelQx without being induced prior to exposure. The animals that were given metabolizing enzyme inducing compounds prior to being given 
MelQx formed a greater number of each type of DNA adduct. The results of the experiment showed that cytochrome P450 isozymes are involved in the formation of DNA adducts (28).

Turesky et al. demonstrated that the primary detoxified metabolites found in the urine of rats were the phase II conjugates, MelQx-N2-sulfamate and MelQx- $\mathrm{N}^{2}$-glucuronide (32). At the high doses $(20 \mathrm{mg} / \mathrm{kg})$ used in the study, the sulfamate pathway was the major detoxification route, while at the low doses $(0.01,0.2 \mathrm{mg} / \mathrm{kg})$ the glucuronide pathway was the most important for elimination. As part of the same study, liver microsomes transformed MelQx to the genotoxic metabolite 2-hydroxyamino-3,8-dimethylimidazo $[4,5 f] q u i n o x a l i n e(H N O H-M e l Q x)(32)$. This was not demonstrated in vivo, although it has been shown that $\mathrm{N}$-hydroxy metabolites are further activated and bind to DNA (32).

\section{Dose Response and DNA Adduct Formation}

In addition to the effects of xenobiotic metabolism on DNA adduct formation, the effect of dose on DNA adducts has also been examined. The results of a dose response study performed by Yamashita (8) showed a linear dose response relationship in the formation of DNA adducts in rats as a result of exposure to MelQx at $0.4 \mathrm{ppm}, 4 \mathrm{ppm}, 40 \mathrm{ppm}$, and $400 \mathrm{ppm}$. This showed a steady rate of increase in adduct levels with increasing dose levels. During this twelve week study, adduct levels reached steady-state levels at every dose in all tissues that were examined. The DNA adduct levels in many of the tissues of rats fed the high dose of $400 \mathrm{ppm}$ MelQx reached a maximum level and then remained high or even declined slightly prior to reaching a steady state of adduct levels by 4 weeks of exposure (8). 
The results of all the work done to date with the food derived heterocyclic amines, including MelQx, indicates that heterocyclic amines are genotoxic and carcinogenic in animals at high doses, and thus have the potential to adversely affect human health. There are, however, still many unanswered questions. Do these compounds exhibit the same sorts of toxicity when they are present at the levels of human consumption ? Are there any other factors that modulate the toxicity of these compounds? What is the relationship between DNA adducts and carcinogenesis?

The mutagenic and carcinogenic activities of these compounds make cooked meat an important source of carcinogens for humans. Although many of the heterocyclic amines have been identified, their in vivo effects have not been fully characterized, nor have the metabolic pathways for toxicity and detoxification been fully established. Also, the mechanisms by which the heterocyclic amines bind to DNA are still being investigated. The abundance of heterocyclic amine precursors in the diet combined with their potent mutagenicity and carcinogenicity is the reason this family of compounds needs to be fully characterized. Once the heterocyclic amines are fully understood, proper assessment of the risk they represent can be made. Currently they must be regarded as potentially important carcinogens because of the high incidence of tumors in rodents fed these particular heterocyclic amines. 


\section{Accelerator Mass Spectrometry}

Even though it appears that quantitation of DNA adducts can be used for dosimetry, ascertaining the amount of carcinogen bound to DNA poses some difficulties. Dosimetry is involved with assessing the amount of chemical that arrives at the target site and causes damage. Historically, radioisotope binding, immunoassay and more recently the $32 \mathrm{P}$-Postlabeling method have been used to measure the relationship between adduct formation and carcinogen exposure. Although one adduct in $10^{10}$ nucleotides can be detected, quantitative measurement is most reliable in the range of one adduct in $10^{7}$ to $10^{8}$ nucleotides. The disadvantages of these methods are a lack of sensitivity at relevant dose levels and various assay specific problems. Recently accelerator mass spectrometry (AMS) has been applied to the problem of biomedical dosimetry. Rodents were exposed to MelQx at levels approximately equivalent to human exposure levels (29). The levels of DNA adducts formed by the exposure were then measured using AMS. Briefly, the technique involved feeding carbon-14 labeled heterocyclic amines to the animal, euthanasia, removing selected tissues, isolating DNA, and finally preparing the sample for analysis by AMS where the amount of carbon-14 present was measured. From this measurement DNA adducts were quantified. The detailed methodology will be fully explained in the methods section.

AMS is therefore used to determine the amount of carbon- 14 associated with DNA. It should be noted that the carbon-14 above natural levels is assumed to be associated with MelQx and not to dissociate from the compound or the metabolites. If this assumption is true, AMS is a valid method of tracing the chemical. Metabolism studies have shown that both DNA reactive and non DNA reactive metabolites contain the labeled carbon. 
The use of AMS in biomedical research is relatively new. In fact the Accelerator at the Lawrence Livermore National Laboratory (LLNL) is currently the only AMS site were a large percentage of the samples measured are biomedical. AMS has been and continues to be used extensively for geological and earth science work. The application of AMS to measurements of very small quantities of radio tracers in biological systems, that are undetectable by current methodology, has only been done to date at Livermore. The reason for this is that added radioisotopes used as tracers are a source of random contamination. Although this can be true, methods have been developed by the LLNL research team to control and virtually eliminate random contamination $(33,34,35,36)$.

\section{AMS of Heterocyclic Amines}

In the most recent AMS work involving MelQx, the formation of DNA adducts was dose dependent down to $500 \mathrm{ng} / \mathrm{kg}$ of body weight in a single oral dose (29). The same study also showed that a radiolabeled non-genotoxic compound 2,3,7,8-tetrachlordibenzo-p-dioxin (TCDD) did not bind to DNA. This pioneering study indicated that not only was the use of AMS valid for measuring DNA adducts formed by labeled genotoxic compounds, but also that the technique has extreme sensitivity such that low level exposures like those encountered in humans can be measured in animals. 
The Accelerator Mass Spectrometer was also recently used to measure low level biological dosimetry following administration to mice of a single oral dose $(41 \mathrm{ng} / \mathrm{kg})$ of $\left[{ }^{14} \mathrm{C}\right] \mathrm{PhIP}$. This dose level in mice is the human equivalent of ingesting $200 \mathrm{~g}$ of cooked beef. The study demonstrated that PhIP is quickly absorbed and distributed to many tissues, followed by rapid excretion. The PhIP concentrations peaked within 3 hours and reached the highest levels in the tissues of the gastrointestinal tract followed by the liver, kidney, pancreas, and thymus (37).

Using these studies done with AMS, and previous work done with MelQx as a foundation, this thesis research project investigated what effect dietary composition has on the level and distribution of MelQx in rodent tissues and on DNA adduct formation as a result of extended exposure to MelQx at an exposure level relevant to humans. The relationships between diet, dose, tissue levels, and DNA adduct formation were determined. The effect of diet was investigated by feeding rats MelQx in two diet matrices and comparing the tissue levels and DNA adducts formed in liver DNA. Data from this thesis will also be compared with previous work on the effects of 2-amino-3,8-dimethylimidazo[4,5-f]quinoxaline on rodents. 


\section{MATERIALS AND METHODS}

Two sub-chronic (42 day) feeding experiments were performed during the course of the thesis research. The first experiment tested feasibility of the approach, and was used to develop techniques. The second study compares the effects of diet on tissue levels and DNA adduct formation.

\section{MelQx Radiopurification and Purity}

The radiopurity of the $[2-14 \mathrm{C}] \mathrm{MeIQx}$ was determined by reverse phase chromatography using a Hewlett-Packard model 1084B High Performance Liquid Chromatograph (HPLC), with an ultraviolet (UV) detector (LDC Analytical Spectromonitor 3100), and a C18 column (TSK ODS-80, particle size $5 \mu \mathrm{m}$ ). MelQx was previously determined to maximally absorb U.V. light at $274 \mathrm{~nm}$ (5) The "A" solvent was water and $0.1 \%$ diethylamine at $\mathrm{pH} 4.0$, the "B" solvent consisted of methanol/water $(35 \% / 65 \%)$. Flow rate was $1 \mathrm{ml} / \mathrm{min}(70 \% \mathrm{~A} / 30 \% \mathrm{~B})$. Aliquots $(5 \mu \mathrm{l})$ of a standard MelQx (purchased from Toronto Research Chemicals) was injected prior to analyzing the sample for comparative purposes. The sample was then injected and fractions were collected at one minute intervals and the carbon-14 associated with the MelQx peak was determined by liquid scintillation counting (Beckman Scintillation Counter Model CS8100) from each fraction collected. The fractions associated with the MelQx peak were pooled and a sample of the pooled fractions was injected into the same HPLC system, radioactivity was quantitated, and this $[2-14 \mathrm{C}] \mathrm{MelQx}$ was used to spike the diets for the diet comparison study. Radiopurity was $98 \%$. 


\section{Diet Preparation and Analysis}

\section{Feasibility Experiment}

Two diets were fed to rats during the first experiment. This was done to: a) determine if rats could be fed hamburger for an extended time, and $b$ ) to determine if $\left[2-{ }^{14} \mathrm{C}\right] \mathrm{Mel} \mathrm{x}$ could be detected in rodent tissues and DNA when fed to the animals at levels roughly equivalent to human exposure. The diets for the feasibility experiment were prepared as follows: raw ground beef (22\% fat) was obtained at a local market. MelQx was added to the meat by diluting $38.8 \mu \mathrm{l}$ of $[2-14 \mathrm{C}] \mathrm{MelQx}(2745 \mathrm{dpm} / \mu \mathrm{l}, 50 \mathrm{mCi} / \mathrm{mMol})$ in $400 \mathrm{ml}$ of acidified water (pH 3.0) and slowly adding the solution to the meat while mixing the meat in a large industrial mixer (Hobart model 3001). The meat was mixed for 2.5 hours. Samples were then taken for analysis by AMS.

\section{Diet Comparison Experiment}

The hamburger diet for the diet comparison experiment was prepared as follows: raw ground beef ( $\leq 30 \%$ fat) was obtained at a local market. The meat was formed into patties $20 \mathrm{~cm} \times 20 \mathrm{~cm} \times 2$ $\mathrm{cm}$ and were microwaved on the "high" setting for four minutes to remove the mutagenic precursors, free amino acids and creatine (38). The meat was then fried at $200^{\circ} \mathrm{C}$ for 4 minutes per side. $\mathrm{MelQ}$ was then added to the meat by diluting $1044 \mu \mathrm{l}$ of [2$\left.{ }^{14} \mathrm{C}\right] \mathrm{MelQx}(2745 \mathrm{dpm} / \mu \mathrm{l}, 50 \mathrm{mCi} / \mathrm{mMol})$ in $1000 \mathrm{ml}$ of acidified water $(\mathrm{pH} 3.0)$ and slowly adding the solution to 3470 grams of cooked hamburger, while mixing the meat in a large industrial mixer (Hobart model 3001) for 1 hour. The diet was formulated to have a concentration of $1.6 \mathrm{ng}\left[2-{ }^{14} \mathrm{C}\right] \mathrm{MelQx}$ per gram. The meat was then placed into new air tight plastic containers and stored $\left(-20^{\circ} \mathrm{C}\right)$ until fed to the animals. 
Commercial laboratory chow containing $[2-14 \mathrm{C}] \mathrm{MelQx}$ was formulated by adding $1110 \mu \mathrm{l}$ of [2-14C]MelQx in $4000 \mathrm{ml}$ of acid water ( $\mathrm{pH} 3.0$ ) to 5000 grams of powdered rat chow (Simonsen Laboratories Rat maintenance diet). The diet was formulated to have a concentration of $1.183 \mathrm{ng}$ of $\left[2-{ }^{-14} \mathrm{C}\right] \mathrm{MelQx}$ per gram of chow. The chow was then mixed in an industrial mixer for 1 hour and dried by placing it on foil in an oven at $250^{\circ} \mathrm{C}$ for $1-2$ hours. The diet was finely powdered by placing it into a blender (Patteson Kelley Twin Shell Dry Blender) The diet was then transferred to new air tight. plastic containers and stored at $-20^{\circ} \mathrm{C}$ until used.

The control diet was formulated in the same manner as the test diet except no $[2-14 \mathrm{C}] \mathrm{MelQx}$ was added into the acid water. The rats fed the standard chow were given diet as received from the manufacturer with no additives.

Diet Analysis for MelQx

The diet for the feasibility experiment was measured by AMS to quantitate $[2-14 \mathrm{C}] \mathrm{MelQx}$. HPLC was used to to determine if any unlabeled MelQx was present and also for comparative purposes. AMS measurement was done following the procedure outlined at the end of this section. Prior to measuring the samples by reverse phase HPLC, the samples were prepared by the "Gross" method $(38,39)$. This procedure is outlined in Appendix 3. Briefly a sample containing any one of 12 heterocyclic amines is solublized and extracted to remove and concentrate the heterocyclic amines, prior to analysis as described in the radiopurification method section. 
The cooked hamburger diet for the diet comparison experiment was analyzed by AMS for $\left[2-{ }^{14} \mathrm{C}\right] \mathrm{MelQx}$, HPLC for total MelQx, and comparative purposes, and by Ames Test for total mutagenic activity and comparative purposes. The test chow was analyzed by AMS and the Ames Test. The control chows were analyzed by AMS. The Ames test was done by the method described by Ames in 1975 (14). The procedure used is listed in Appendix 4. Briefly the sample was incubated with a 59 mix prior to being added to Ames bacterial strain TA 98 and grown on minimal glucose plates for 48 hours. The bacterial colonies were then scored by using an automated colony counter (New Brunswick Scientific Biotran II) with the Ames fit software program (Microsoft Excel Biotran version 9).

\section{Second Radiolabeled Chow Diet}

At the conclusion of the diet comparison experiment the actual diets were determined to contain MelQx at concentrations too different for comparison. The difference was probably due to a spiking error during formulation, but it was not revealed until carbon analysis was done on the diets. An additional chow diet was then formulated in the same manner as the test chow diet in the feasibility experiment. This diet was then immediately analyzed and determined to be spiked at the desired level. This diet was fed to 3 rats for 7 days and used for comparing the effect the two diets had on tissue levels of MelQx and DNA adducts. 


\section{Animals}

Male Sprague-Dawley rats (6 weeks old at the start of experiment) were housed on raised floor stainless steel cages one per cage, over absorbent paper, which was changed twice weekly. They were given water ad libitum. For the feasibility experiment no vitamins were added to the water for the first 12 days. From day 12 on all rats received vitamin-supplemented water (Shaklee Vita-Lea 1 teaspoon/ $4 \mathrm{oz}$. water) and on day 13 each rat was also given one pellet of rat chow $(4.5 \mathrm{~g})$ in addition to the ground beef due to diarrhea. One 20 gram ground beef "meat ball" was placed into a trough feeder each day. Rats were checked each day before being fed, and any uneaten food was weighed and recorded. The rats were weighed at the start of the study and every 7 days. The rats were monitored during feeding for any symptoms of toxicity, such as lethargy, weight loss, rough hair coat, loss of appetite, or hunched back.

TABLE 5

Planned Dosing Regime for Feasibility Experiment.

Test Rats

Raw Hamburger

Control Rats
$20 \mathrm{~g}$ hamburger/day.

$1 \mathrm{ng}$ [2-14C]MelQx/g of raw hamburger $20 \mathrm{ng} / \mathrm{day}$

$20 \mathrm{~g}$ of raw hamburger/day.

No $[2.14 \mathrm{C}] \mathrm{Mel} Q \mathrm{Q}$ was added. 
For the diet comparison experiment all diets were given to the rats in glass dishes (Kimax No. $230080 \times 30$ ) placed inside the cage. The powder diets were weighed out in the dish then $2-3 \mathrm{ml}$ of sterile water was sprayed onto the feed to form a paste. This was done to minimize the amount of food dropped out the bottom of the cage by the animals. Diets were designed to be isocaloric and were fed on a restricted basis. Each rat's weight was recorded at the start of the study, and then every seven days until the animal was euthanized. Animals for this particular study were randomized at the beginning of the study by using the cage card shuffling method (40).

TABLE 6

Planned Dosing Regime for Diet Comparison Experiment.

Diet Weight/ Kcals per day $n g[2-14 \mathrm{C}] \mathrm{Mel} \mathrm{Q} \times \mathrm{g}$ diet TTotal Daily Dose

\begin{tabular}{|l|l|l|}
\hline Standard Rodent Chow Diet & $16.9 \mathrm{~g}, 47.75 \mathrm{Kcals}$ & $0 / 0$ \\
\hline Control Rodent Chow Diet & $16.9 \mathrm{~g}, 47.75 \mathrm{Kcals}$ & $0 / 0$ \\
\hline Hamburgert & $12.5 \mathrm{~g}, 29.125 \mathrm{Kcals}$ & $1.600 \mathrm{ng} / \mathrm{g} / 20 \mathrm{ng} \mathrm{per}$ day \\
Standard Rodent Chow & $6.58 \mathrm{~g}, 18.625 \mathrm{Kcals}$ & \\
\hline Test Rodent Chow & $16.9 \mathrm{~g}, 47.75 \mathrm{Kcals}$ & $1.1834 \mathrm{ng} / \mathrm{g} / 20 \mathrm{ng} \mathrm{per}$ day \\
\hline
\end{tabular}




\section{Tissue Removal and Storage}

Animals were euthanized $24 \mathrm{~h}$ after their last feeding, at $1,7,14,28$, and 42 days. The rats were weighed and then placed into a $\mathrm{CO}_{2}$ chamber. The necropsy was performed in a clean necropsy facility. The thymus, heart, lungs, liver, spleen, pancreas, kidneys, and blood were removed from each animal. Each organ was placed separately into new capped glass vials and stored at $-20^{\circ} \mathrm{C}$ until samples were taken for DNA isolation or AMS measurement of MelQx levels present in the tissues. Each test group of animals were necropsied with a clean, sterile, and different set of instruments that were cleaned in between individual animals.

\section{Sample Preparation for AMS $(33,34)$}

Tissue samples from 5 to $30 \mathrm{mg}$ were removed from individual organs, by cutting the frozen tissue with a new sterile disposable 18 gauge needle. To minimize possible contamination, new gloves and fresh paper on the work surface were used for each sample. The tissue was then placed into a previously baked $\left(500^{\circ} \mathrm{C} 2 \mathrm{~h}\right.$ to remove any carbon) $6 \times 50 \mathrm{~mm}$ (Kimble borosilicate glass culture) tube carried inside an $12 \times 75 \mathrm{~mm}$ test tube (borosilicate glass). Isolated DNA was pipetted into the $6 \times 50 \mathrm{~mm}$ tubes.

DNA was isolated using the protocol outlined in Appendix 1. Briefly, the selected tissues were lysed and then applied to anion exchange columns (Qiagen tip-500). The DNA concentration was quantified and checked for purity by measuring the absorbance from $200 \mathrm{~nm}$ to $300 \mathrm{~nm}$ (a $260 / 280 \mathrm{~nm}$ ratio of 1.8 , and $230 / 260 \mathrm{~nm}$ ratio of approximately 0.4 was considered purified) on a UV-Vis spectrophotometer (Shimadzu UV-Vis UV-2100 recording spectrophotometer) prior to drying it down and preparing it for carbon-14 measurement by AMS. (see Appendix 1 for protocol) 
The samples were dried by vacuum centrifugation (Savant speed vac concentrator model SVC-100H) and oxidized by adding 0.25 $-1 \mathrm{~g}$ of cupric oxide to each $6 \times 50 \mathrm{~mm}$ tube. Enough $\mathrm{CuO}_{2}$ was added to ensure complete oxidation and silver wire $(\approx 3 \mathrm{~mm})$ is added to each sample to bind Cl. The $6 \times 50 \mathrm{~mm}$ tube is then placed into a $9 \times$ $150 \mathrm{~mm}$ quartz closed-ended, combustion tubes. Tubes were heated to $500^{\circ} \mathrm{C}$ for $2 \mathrm{~h}$ prior to use to remove any surface carbon. These tubes were evacuated ( $\leq 250$ mTorr) and sealed at an approximate length of about $100 \mathrm{~mm}$ using an oxy-acetylene torch. Each sealed, evacuated tube was placed into an individual steel or ceramic tube within an array. The tubes were heated to $650^{\circ} \mathrm{C}$ in a muffle furnace for 2 hours, after which they were slowly cooled. Carbon dioxide and water were then separated from the other combustion products, primarily nitrogen, by cryogenic separation. 


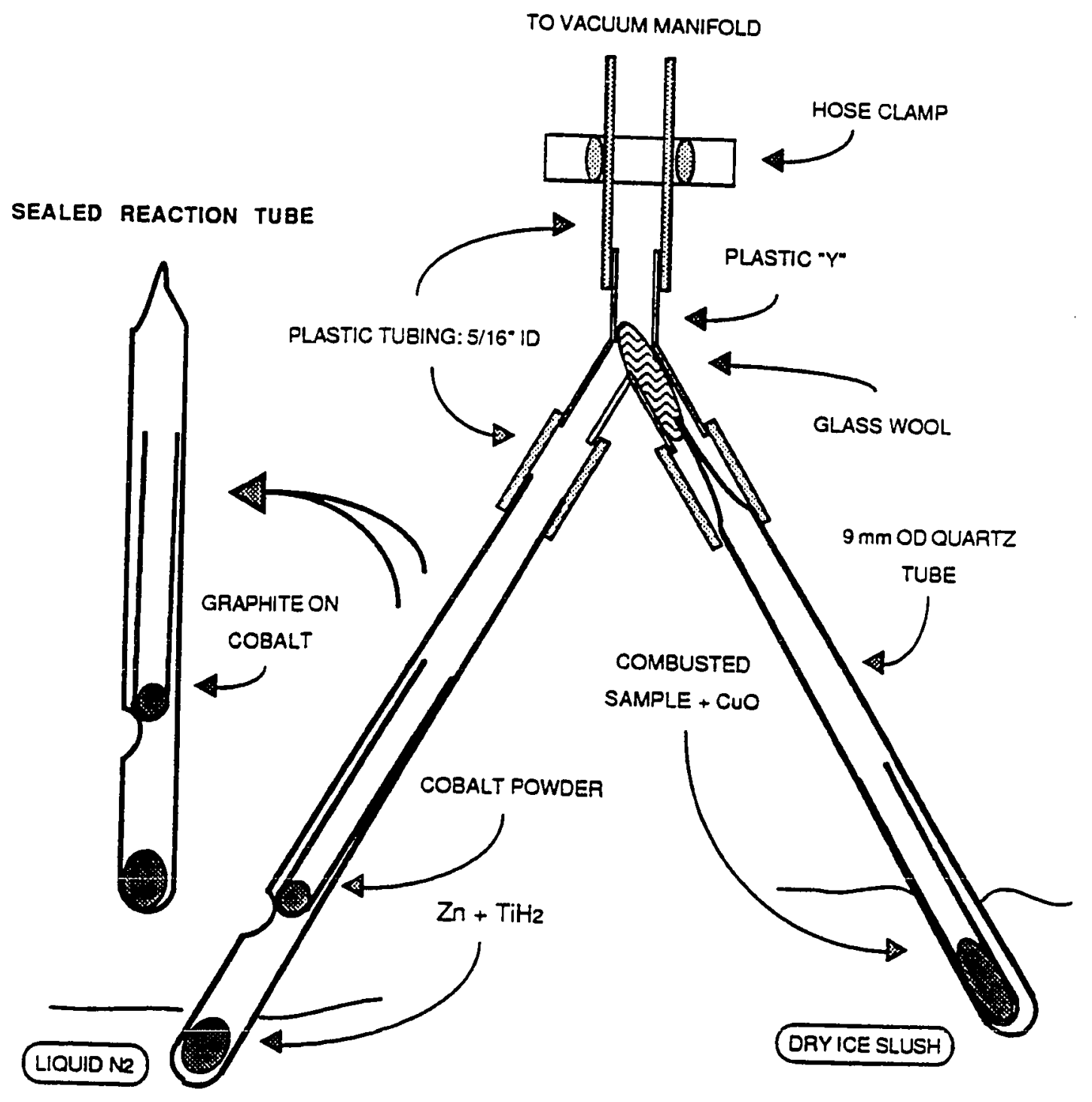

FIGURE 4. Disposable Cryogenic Separation Transfer Manifold (36). 
The separation of the carbon dioxide from the other combustion products was done in a such a way as to avoid cross contamination of samples which could have occurred through gas adsorption or desorption on the walls of a common manifold. The method used employed a new disposable transfer manifold for each sample (Figure 4). The quartz tubes were produced so that the initial closed end came to a thin breakable point. The point was inserted into a short length $(2-3 \mathrm{~cm})$ of $5 / 16$ " i.d. flexible plastic tubing (tygon), which was connected to one short arm of an inverted hard plastic (polypropylene) ' $Y$ '. The other short end of the inverted ' $Y$ ' was connected to another short length $(3-4 \mathrm{~cm}$ ) length of flexible plastic tubing which was attached to a $9 \times 150 \mathrm{~mm}$ closed end, borosilicate glass tube which contained a metal catalyst, cobalt powder (1-5 $\mathrm{mg}$ per $\mathrm{mg}$ of expected carbon) and reactants, zinc ( $\sim 20$ $\mathrm{mg}$ ) and titanium hydride ( $\sim 10 \mathrm{mg})$. The long arm of the plastic ' $\mathrm{Y}$ ' was connected via a length of flexible plastic tubing approximately 5 to $6 \mathrm{~cm}$ to an evacuation manifold. The assembly was evacuated to $\leq 250$ mTorr. The combustion tube was then immersed in a dewar flask containing a dry ice/alcohol slush in order to retain the water resulting from the combustion of sample in the combustion tube. The other glass reaction tube was immersed in a dewar flask containing liquid nitrogen. After evacuation a hose clamp sealed the plastic assembly from the evacuation port. The weak point of the combustion tube was broken by pressing it against the inside of the hard plastic ' $Y$ '. The released carbon dioxide was frozen into the borosilicate glass reaction tube. Enough time was allowed for complete condensation of the carbon dioxide to occur, then the hose clamp was removed and the nitrogen gas from the combustion of the sample is pumped off by vacuum. The borosilicate glass tube was then sealed using a torch. The sealed tube was then allowed to warm with the carbon dioxide trapped within it. The sealed tube was then heated to $550^{\circ} \mathrm{C}$ for 8 hours in a muffle furnace. This caused the carbon dioxide to be reduced to filamentous graphite on the cobalt catalyst. The filamentous graphite is a solid material 
which was then removed from the sealed tube and pressed into an aluminum planchet. The sample was handled at all times in such a manner as to avoid contamination $(33,34)$. The graphite is measured by AMS.

\section{Accelerator Mass Spectrometry}

The technique of accelerator mass spectrometry was used in this thesis because of its great sensitivity. AMS counts the number of carbon-14 nuclei directly instead of measuring their rate of decay (41). This allows extremely low levels of carbon-14 to be used as a tracer and still be accurately measured. AMS uses two mass spectrometers separated by an accelerator (Figure 5), that functions as a molecular dissociator and an energy multiplier. A cesium-sputter (fast atom bombardment) ion source converts a fraction of the atoms in the solid sample into negative ions at $\geq 30$ $\mathrm{keV}$. Approximately $1 \mathrm{mg}$ of solid sample is required, in a form that is thermally conducting and of low volatility. Much of the solid sample may be a carrier of diluent such as cetylpyridinuium chloride (Sigma Chemical Co.) or tricine ( $\mathrm{N}$-tris[hydroxymethyl]-

methylglycine, Sigma Chemical Co.). Once the negative ions (C-) are formed they are sorted by a low energy mass spectrometer which selects a single mass (mass resolution, $M /$ delta $M=100$ ) The ion is then injected into the accelerator beam tube, and the increasing positive potential in the beam tube accelerates the negative ion toward the 2-15 MeV terminal in the center of the tandem accelerator. The ions pass through a thin carbon foil $\left(5 \mathrm{ug} / \mathrm{cm}^{2}\right)$ which strips off the outer electrons, and produces positive ions and simultaneously dissociates all molecules. The positive ions are then accelerated toward ground potential. Quadrapole lenses select and focus the ion and charge state of interest $\left(\mathrm{C}^{4+}\right)$ from the other ions and distribution states produced by the accelerator. A second high energy mass spectrometer separates the ions of the rare isotope 
from the ion beam of the common isotope, which is $13 \mathrm{C} 4+$ when ${ }^{14} \mathrm{C}^{4+}$ is being counted. The ${ }^{13} \mathrm{C}^{4+}$ is measured in an off center Faraday cup. The centered rare isotope, ${ }^{14} \mathrm{C}^{4+}$, is further selected for by momentum selection through a magnet, by velocity selection through crossed electric and magnetic fields, and finally by individual ion identification in a multi-anode gas ionization detector. Analysis is based on the ratio of ${ }^{13} \mathrm{C}$ to ${ }^{14} \mathrm{C}$ and is determined by measuring the ${ }^{13} \mathrm{C}$ and ${ }^{14} \mathrm{C}$ nuclei. The ratio of the unknown sample is divided by the ${ }^{13} \mathrm{C}$ to ${ }^{14} \mathrm{C}$ ratio of a known standard (Australian National University sugar 1.508 Modern). The ratio of the unknown sample to the known standard is multiplied by 1.52. This value incorporates a correction factor needed due to the difference between the carbon 13/12 content of the standards and the unknown. ANU sugar, the working standard for AMS, is known to be 1.508 modern. There is a correction factor (0.989) due to carbon $13 / 12$ differences, so $1.508 / 0.989=1.52$, is the correction factor to change the ratios of the unknown with respect to the sugar standard into ratios with respect to modern. This gives the unknown sample in terms of modern (41). The spectrometer used was housed at the Lawrence Livermore National Laboratory/ University of California Accelerator Mass Spectrometry facility. The accelerator is a tandem electrostatic (Van de Graff) accelerator. 


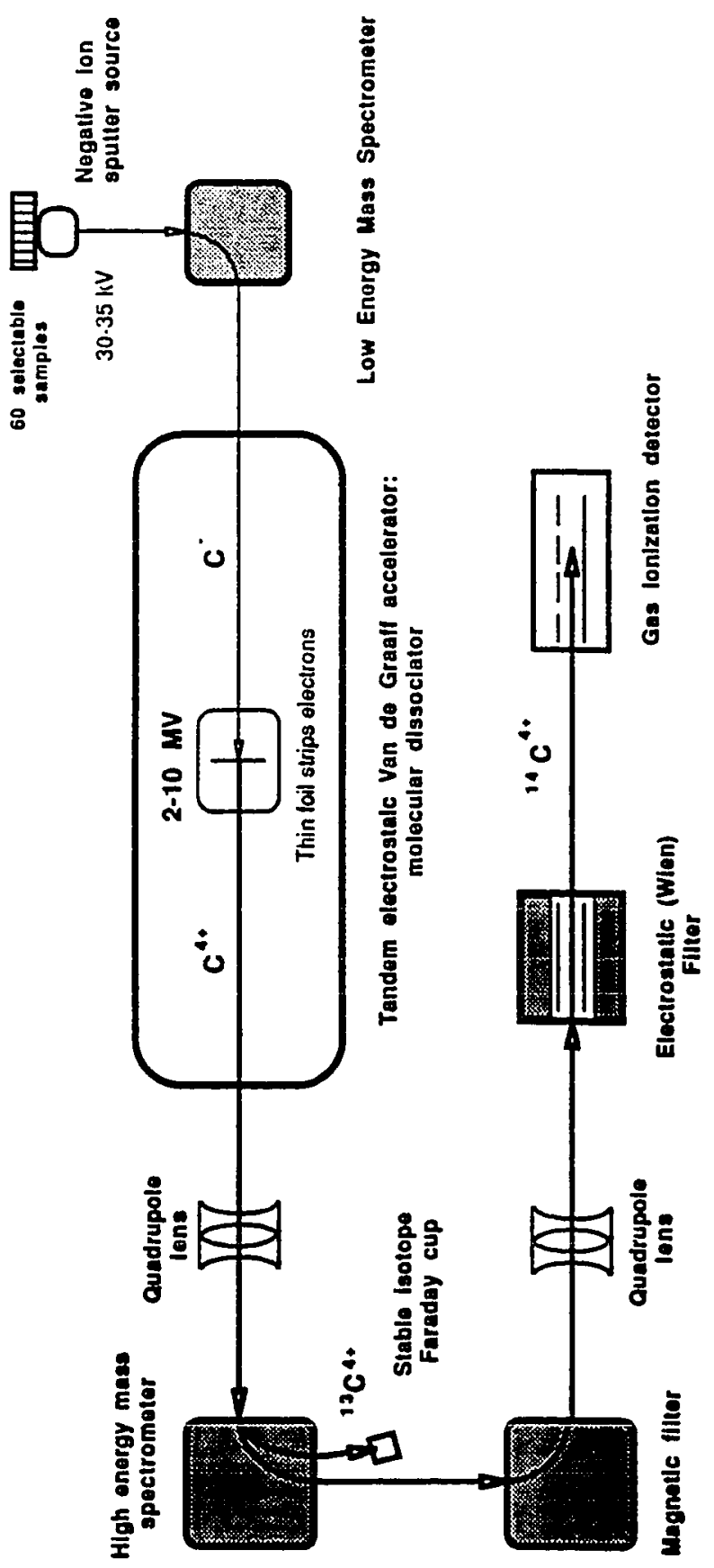

FIGURE 5. Schematic of Accelerator Mass Spectrometer (35). 


\section{Carbon Analysis of Diets, Tissues, and DNA}

The diets, rat tissues and DNA were analyzed for carbon using a Carlo Erba NA 1500 series 2 nitrogen/ carbon/ sulphur analyzer. The carbon percentage is used in calculating the amount of [2$\left.{ }^{14} \mathrm{C}\right] \mathrm{MelQx}$ present in the sample (see Appendix 2).

\section{Modern}

Samples measured by AMS are quantitated in terms of modern. Modern is a term that states how many carbon- 14 atoms are present when compared to contemporary levels. "Modern" is defined as $5.9 \mathrm{x}$ $10^{10}$ carbon-14 atoms in one gram of total carbon (42).

\section{Quantitation of MelQx}

After measuring the isotope ratio via accelerator mass spectrometry, and using this ratio to determine carbon-14 levels, the amount of MelQx within the tissue or DNA can be determined. (see Appendix 2 for sample calculations.)

\section{Statistical Analysis}

The analysis of variance (ANOVA) was performed using two statistical software programs (Data Desk by Data Description Inc. Version 3.0 1988, Ithaca, New York, and Super Anova by Abacus Concepts Inc. Version 1.1 1991, Berkeley, CA) The level of significance was set a priori at $p \leq 0.05$. One sample of each tissue was taken for every rat at each time point. Triplicate measurements of carbon-14 were made by AMS. The mean of these triplicate determinations was then used in the analysis of variance (ANOVA). 


\section{RESULTS}

\section{Analysis of Diets}

The diets were analyzed by the Ames/Salmonella test, HPLC and AMS. The HPLC analysis incorporated the "Gross" method (39) for quantification of MelQx. The Ames test measured total mutagenic activity of extracted samples (39) using Salmonella typhimurium strain TA 98 (38). AMS was used to analyze the carbon-14 nuclei associated with MelQx.

\section{TABLE 7}

Analysis of Raw Hamburger Diet from Feasibility Experiment.

\begin{tabular}{|c|c|c|}
\hline Methods of Analysis & MelQx $(n g / g)$ & $N$ \\
\hline HPLC & 2.95 & 2 \\
\hline AMS & $2.32 \pm 0.15$ & 3 \\
\hline
\end{tabular}

Data are mean, or mean \pm standard deviation for $n=2$ or 3 determinations.

TABLE 8

Analysis of Diets from Diet Comparison Experiment.

\begin{tabular}{|c|c|c|c|}
\hline Method of Analysis & Test Chow Diet & Cooked Hamburger Diet & $\mathrm{N}$ \\
\hline AMS & $\begin{array}{c}0.601 \pm 0.064 \text { (ng } \\
{[2-14 \mathrm{C}]-\text { MelQx/g }} \\
\text { Diet) }\end{array}$ & $\begin{array}{c}1.8 \pm 0.081 \text { (ng [2-14 C] } \\
\text { MelQx/g Diet) }\end{array}$ & 4 \\
\hline HPLC & Not tested. & 3.9 (ng (MelQx/g Diet) & 2 \\
\hline Ames Test Activity & 52 revertants/g & 648 revertants/g & 2 \\
\hline
\end{tabular}


Using both accelerator mass spectrometry to measure carbon14 nuclei and reverse phase chromatography to quantitate $\mathrm{MelQx}$; $98 \%$ of the carbon-14 atoms were associated with [2-14 C]MelQx. The HPLC method quantitated four heterocyclic amines MelQx, PhIP, 4,8-DiMelQx, and IQ derived from cooked meat. The Ames test measured the total mutagenic activity. The mutagenic activity can then be compared to previous work, in which the mutagenic activity of known quantities of heterocyclic amines were determined, to give an estimate of the MelQx concentration. The test chow diet was not expected to contain any mutagens other than the MelQx that was spiked into the diet. As shown in Table 8, there were 52 revertants, per gram above background revertants of test chow whereas the cooked hamburger diet had 648 revertants per gram. By measuring mutagenic activity, the level of MelQx can be estimated to be 0.36 to $0.9 \mathrm{ng}$ of MelQx per gram of diet. This estimation depends on the reference used for the number of revertants formed per microgram of MelQx $(5,18,42)$. The cooked meat was microwaved prior to cooking to minimize the level of mutagens present. The results of the analysis is shown in Table 8 and demonstrates that the [2${ }^{14}$ C]MelQx comprised at least half of the mutagenic activity. HPLC analysis showed that some MelQx was formed in the cooking process, because unlabeled MelQx was found in the cooked hamburger. The levels of these other mutagens accounts for the additional mutagenic activity seen in the cooked hamburger and not in the test chow diet. 
Analysis of Adjusted Chow Diet

The diet used in adjusted chow diet study for seven days using three rats was measured by AMS and was found to be $2.061 \mathrm{ng}$ [2$\left.{ }^{14} \mathrm{C}\right] \mathrm{MelQx} / \mathrm{g}$ chow diet. Carbon analysis yielded the results shown in Table 9.

\section{Carbon Analysis of Diets, Tissues, and DNA}

TABLE 9

Carbon Content (\%) of Rat Tissues and Diets

\begin{tabular}{|c|c|c|c|}
\hline Sample & Average $\%$ Carbon & Standard Deviation & $\mathrm{N}$ \\
\hline Blood & 7.3 & 0.49 & 3 \\
\hline Heart & 33.8 & 4.93 & 3 \\
\hline Liver & 44.4 & 0.87 & 3 \\
\hline Lungs & 21.2 & 2.13 & 3 \\
\hline Thymus & 33.5 & 3.41 & 3 \\
\hline Spleen & 36.5 & 7.05 & 3 \\
\hline Pancreas & 32.8 & 3.52 & 3 \\
\hline Kidney & 37.1 & 3.11 & 3 \\
\hline Calf Thymus DNAa & 29.0 & 0.52 & 3 \\
\hline $\begin{array}{l}\text { Raw Hamburger Diet. } \\
\text { (Feasibility } \\
\text { Experiment) }\end{array}$ & 44.4 & 9.56 & 3 \\
\hline Cooked Hamburger Diet & 50.6 & 6.12 & 3 \\
\hline $\begin{array}{l}\text { Standard Rodent Chow } \\
\text { Diet }\end{array}$ & 41.9 & 0.51 & 3 \\
\hline $\begin{array}{l}\text { Control Rodent Chow } \\
\text { Diet }\end{array}$ & 41.34 & 0.57 & 3 \\
\hline Test Rodent Chow Diet & 41.85 & 0.51 & 3 \\
\hline
\end{tabular}

aElemental composition of DNA is the same among mammals, thus allowing calf thymus DNA to be used to calculate the percent carbon of mammalian DNA 


\section{Animal Doses}

\section{Feasibility Experiment}

As shown in Table 10, throughout the 42 day study, the average daily consumption of food as well as the average daily dose of MelQx stayed constant.

TABLE 10

Average Doses of Feasibility Experiment.

\begin{tabular}{|l|l|l|l|l|}
\hline TEST GROUP4 & $\begin{array}{l}\text { Avg. amount } \\
\text { of food } \\
\text { eaten } \\
\text { (g/day) }\end{array}$ & $\begin{array}{l}\text { Avg. MelQx } \\
\text { dose } \\
\text { (ng/day) }\end{array}$ & $\begin{array}{l}\text { Avg. MelQx dose } \\
\text { (ng/kg rat body } \\
\text { weight) }{ }^{1}\end{array}$ & $\begin{array}{l}\text { N } \\
\text { (data } \\
\text { points) }\end{array}$ \\
\hline Raw Hamburger $/ 7$ days & 19.8 & 45.5 & 223.04 & 1 \\
\hline Raw Hamburger /14 days & 19.9 & 45.7 & 217.15 & 2 \\
\hline Raw Hamburger $/ 21$ days & 19.9 & 45.8 & $205.99 \pm 18.13$ & 3 \\
\hline Raw Hamburger $/ 28$ days & 19.9 & 45.7 & $196.42 \pm 21.49$ & 4 \\
\hline Raw Hamburger /35 days & 19.9 & 45.9 & $197.06 \pm 27.49$ & 5 \\
\hline Raw Hamburger /42 days & 19.9 & 45.8 & $189.48 \pm 25.84$ & 6 \\
\hline
\end{tabular}

Raw Hamburger Diet $=2.3 \mathrm{ng}\left[2-{ }^{14} \mathrm{C}\right] \mathrm{MelQx} / \mathrm{g}$ of diet. The Average dose value ${ }^{1}$ was obtained by, first averaging a given weeks daily food intake 2 . This average was divided by the weight of the rat at the end of that given week to give a $\mathrm{ng} / \mathrm{kg}$ dose ${ }^{3}$. All the averages with a test group were averaged over the number of weeks that data was obtained for the test group 4.

The rats were given 20 grams of hamburger each day. Prior to each daily feeding, the amount of food not eaten from the previous day was recorded. The total dose given to the rat was calculated by subtracting the food not eaten from the food given. The total food consumed was multiplied by $2.3 \mathrm{ng} \mathrm{MelQx/g}$ of food, to give the dose. 


\section{Diet Comparison Experiment}

The rats were fed one of four diets: standard rodent chow, control chow, test chow, or cooked hamburger. The standard rodent chow and the control chow were used as control diets and the rats received no added $[2-14 \mathrm{C}] \mathrm{MelQx}$. Each rat was given the same number of calories each day. Prior to each daily feeding the amount of food not eaten was recorded for each diet. The total dose the rats received in either the test chow or the cooked hamburger diet was calculated by subtracting the food not eaten from the food given. The total food consumed for the day was multiplied by either 0.601 ng $[2-14 \mathrm{C}] \mathrm{MelQx} / \mathrm{gram}$ for the test chow or by $2.018 \mathrm{ng}$ [2$\left.{ }^{14} \mathrm{C}\right] \mathrm{MelQx} / \mathrm{gram}$ for the cooked hamburger diet. The final result was the daily dose of $\left[2-{ }^{14} \mathrm{C}\right] \mathrm{MelQx}$ per gram of the diet.

TABLE 11

Average Doses of Diet Comparison Experiment.

\begin{tabular}{|l|l|l|l|l|}
\hline $\begin{array}{l}\text { TEST GROUP } \\
\text { (n=3) }\end{array}$ & $\begin{array}{l}\text { Avg. amount of } \\
\text { food eaten/day }\end{array}$ & $\begin{array}{l}\text { Avg. dose } \\
\text { ng/day }\end{array}$ & $\begin{array}{l}\text { Avg. dosea }(\mathrm{ng} / \mathrm{kg} \\
\text { rat body weight) }\end{array}$ & $\begin{array}{l}\mathrm{N} \text { (Data } \\
\text { points) }\end{array}$ \\
\hline Test Chow /1 Day & $12.0 \pm 0.8$ & $7.21 \pm 0.59$ & 38.7 & 1 \\
\hline Test Chow /7 Day & $14.4 \pm 0.44$ & $9.67 \pm 1.76$ & 50.10 & 1 \\
\hline Test Chow /14 Days & $14.93 \pm 0.9$ & $8.97 \pm 0.54$ & 47.59 & 2 \\
\hline Test Chow /28 Days & $15.76 \pm 0.5$ & $9.47 \pm 0.30$ & $48.36 \pm 3.03$ & 4 \\
\hline Test Chow /42 Days & $15.71 \pm 0.04$ & $9.44 \pm 0.02$ & $47.50 \pm 3.63$ & 6 \\
\hline Hamburger /1 Day & $10.30 \pm 0.2$ & $20.81 \pm 0.40$ & 117.13 & 1 \\
\hline Hamburger /7 Days & $10.74 \pm 0.83$ & $21.69 \pm 1.68$ & 106.5 & 1 \\
\hline Hamburger /14 Days & $11.24 \pm 0.09$ & $22.71 \pm 1.14$ & 109.99 & 2 \\
\hline Hamburger /28 Days & $11.39 \pm 0.09$ & $23.01 \pm 0.18$ & $99.76 \pm 6.60$ & 4 \\
\hline Hamburger /42 Days & $11.36 \pm 0.47$ & $22.94 \pm 0.67$ & $96.89 \pm 8.76$ & 6 \\
\hline
\end{tabular}

a Dose is $\mathrm{ng} /$ day of $\left[2-{ }^{14} \mathrm{C}\right] \mathrm{MelQx}$. All $\left[2{ }^{-14} \mathrm{C}\right] \mathrm{MelQx}$ was in the hamburger.

$\left[2-{ }^{14} \mathrm{C}\right] \mathrm{MelQx}$ chow $=0.601 \mathrm{ng} / \mathrm{g}$ diet, rats fed $16.9 \mathrm{~g} / \mathrm{day}$

Cooked hamburger diet $=2.018 \mathrm{ng} / \mathrm{g}$ diet, rats fed $12.5 \mathrm{~g} / \mathrm{day}$ of hamburger and $6.6 \mathrm{~g}$ of rodent chow. 


\section{Adjusted Chow Diet}

The three rats fed the correction factor diet for seven days received an average of dose of $21.64 \pm 0.07 \mathrm{ng} /$ day. The average dose per body weight was $117.02 \pm 3.06 \mathrm{ng} / \mathrm{kg}$.

\section{Animal Weights}

\section{Feasibility Experiment}

Although the animals for this study were not randomized prior to group assignment, it did appear that the control group grew at a slightly faster rate than the test animals, but it does not appear to be statistically significant. (Table 12) 


\section{Diet Comparison Experiment}

TABLE 12

\section{Percent Change in Rat Body Weight Over Time}

\begin{tabular}{|c|c|c|c|c|c|c|}
\hline Test Group/ Days on Diet & WEEK 1 & WEEK 2 & WEEK 3 & WEEK 4 & WEEK 5 & WEEK 6 \\
\hline $\begin{array}{l}\text { Standard Rodent Chow/ } \\
42 \text { Days }\end{array}$ & $17.3 \%$ & $9.16 \%$ & $8.25 \%$ & $5.26 \%$ & $4.87 \%$ & $5.95 \%$ \\
\hline Control Chow/ 42 Days & $-2.65 \%$ & $3.99 \%$ & $5.41 \%$ & $5.13 \%$ & $3.46 \%$ & $4.26 \%$ \\
\hline Test Chow/ 1 Day & $\ldots \ldots \ldots$ & $\ldots \ldots \ldots$ & $\ldots \ldots$ & $\ldots$ & $\ldots \ldots \ldots$ & $\ldots \ldots+n$ \\
\hline Test Chow/ 7 Day & $1.94 \%$ & $\ldots \ldots$ & $\ldots \ldots$ & $\ldots \ldots \ldots$ & $\ldots \ldots \ldots$ & $\ldots \ldots \ldots$ \\
\hline Test Chow/ 14 Day & $-1.24 \%$ & $3.05 \%$ & $\ldots \ldots$ & $\ldots \ldots$ & $\ldots \ldots \ldots$ & $\ldots \ldots \ldots$ \\
\hline Test Chow/ 28 Day & $1.28 \%$ & $3.43 \%$ & $4.01 \%$ & $5.37 \%$ & $\ldots \ldots$ & $\ldots \ldots \ldots$ \\
\hline Test Chow/ 42 Day & $-3.1 \%$ & $4.32 \%$ & $6.13 \%$ & $3.9 \%$ & $3.1 \%$ & $4.6 \%$ \\
\hline Hamburger/ 1 Day & $\ldots \ldots$ & $\ldots \ldots \ldots$ & $\ldots \ldots$ & $\ldots \ldots \ldots$ & $\ldots \ldots \ldots$ & $\ldots \ldots$ \\
\hline Hamburger/ 7 Day & $9.3 \%$ & $\ldots \ldots$ & & $\ldots \ldots \ldots$ & $\ldots \ldots \ldots$ & $\ldots \ldots$ \\
\hline Hamburger/14 Day & $10.47 \%$ & $9.81 \%$ & $\ldots \ldots$ & $\ldots \ldots \ldots$ & $\ldots \ldots$ & $\ldots \ldots$ \\
\hline Hamburger/ 28 Day & $9.46 \%$ & $9.14 \%$ & $8.22 \%$ & $7.04 \%$ & $\ldots \ldots$ & $\ldots \ldots$ \\
\hline Hamburger/ 42 Day & $10.29 \%$ & $7.2 \%$ & $7.33 \%$ & $5.26 \%$ & $4.59 \%$ & $5.04 \%$ \\
\hline
\end{tabular}

The percent change was calculated by taking the weight from week of interest subtracting the weight from the previous week, dividing that by previous week's weight and multiplying by 100. $n=3$ for each group. 
The growth rates of the different experimental groups as a function of time are shown in Figure 6.

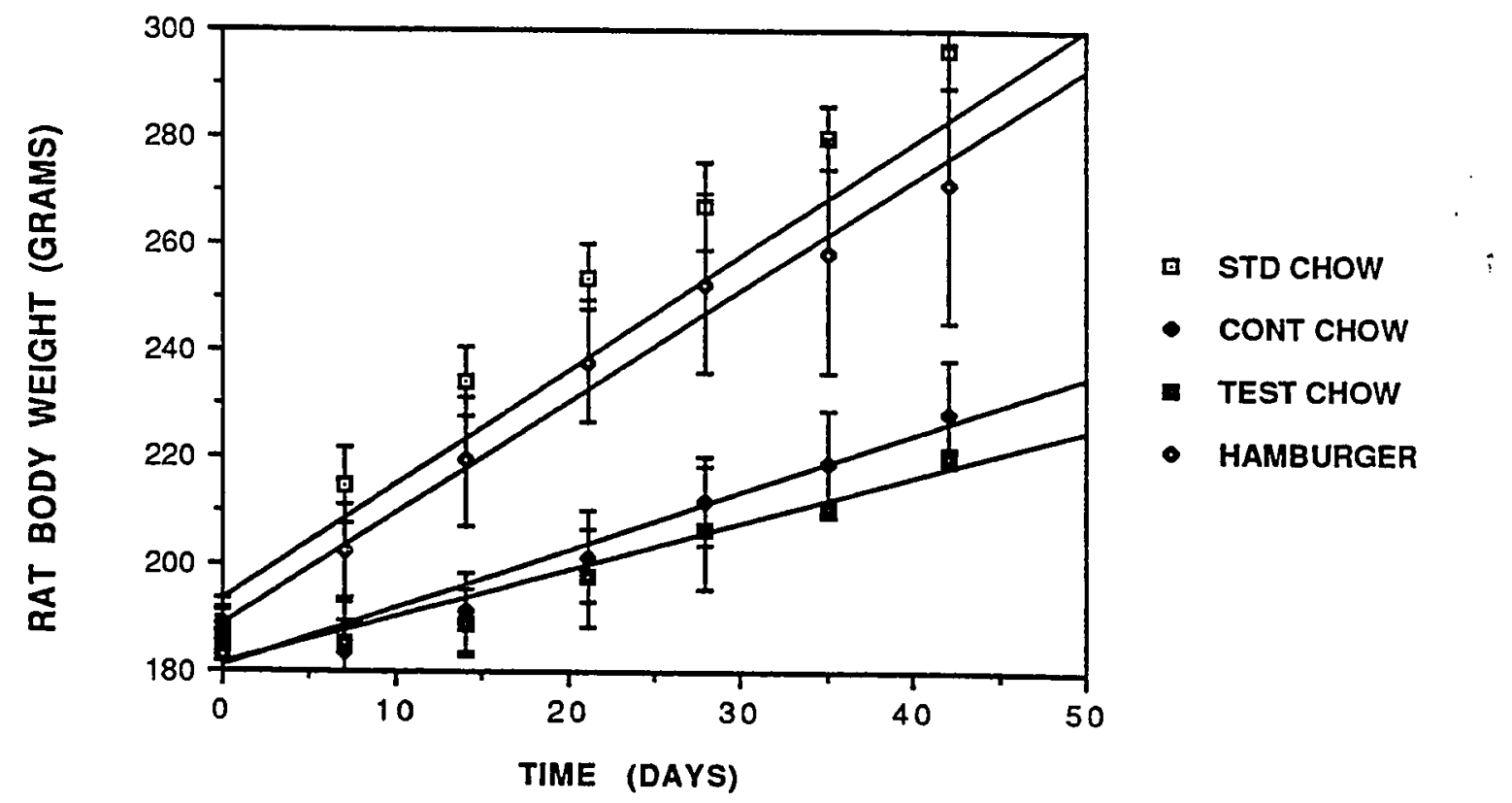

FIGURE 6. Comparison of growth rates from diet comparison experiment between different experimental groups. Data are mean $\pm S D$ for $n=3$ rats. During the course of the 42 day study, one of the control chow rats (\#18) developed an enlarged left eye, that became noticeable on 12/4/91 on day 30 of the study. There was no apparent injury or infection. The animal continued to eat and drink normally until euthanized on day 42.

$\begin{array}{lll}\text { Standard Chow } & y=193.02+2.5735 \times R^{2}=0.977 \\ \text { Control Chow } & y=180.87+1.0719 \times R^{2}=0.930 \\ \text { Test Chow } & y=180.97+0.8693 \times R^{2}=0.949 \\ \text { Cooked Hamburger } & y=188.01+2.0908 \times R^{2}=0.978\end{array}$




\section{Adjusted Chow Diet Study}

The average starting weight for the rats $(n=3)$ was $174 \pm 1.0 \mathrm{~g}$, their average weight at the end of 7 days was $185 \pm 4.36 \mathrm{~g}$. The levels of $[2-14 \mathrm{C}] \mathrm{MelQx}$ in the tissues of the dosed rats are shown in Table 13 (feasibility study) and Table 14 (diet comparison study).

\section{Tissue Levels}

TABLE 13

Average tissue levels of $\left[2-{ }^{14} \mathrm{C}\right] \mathrm{MelQx}$ in Rats in Feasibility Experiment

\begin{tabular}{|l|l|l|l|l|}
\hline $\begin{array}{l}\text { Test Group/ } \\
\text { Days on Diet (n=2) }\end{array}$ & Liver & Heart & Thymus & $\begin{array}{l}\text { Avg Dose } \\
\text { (ng/kg) }\end{array}$ \\
\hline Raw Hamburger Control / 42 Daysa & 0 & 0.32 & 0.01 & 0 \\
\hline Raw Hamburger / 7 Days & 342.44 & 93.01 & 83.70 & 223.04 \\
\hline Raw Hamburger / 14 Days & 331.99 & 108.99 & 130.95 & 217.15 \\
\hline Raw Hamburger / 21 Days & 377.17 & 89.46 & 133.26 & 205.99 \\
\hline Raw Hamburger / 28 Days & 372.16 & 111.43 & 162.09 & 196.42 \\
\hline Raw Hamburger / 35 Days & 367.18 & 100.42 & 130.74 & 197.06 \\
\hline Raw Hamburger / 42 Days & 357.59 & 82.38 & 98.10 & 189.48 \\
\hline
\end{tabular}

a Background value, animals received no known carbon-14. Data are average pg [2-14 C]MelQx $/ g$ tissue for $n=2$. Measurements made using AMS. 
TABLE 14

Average Tissue levels of $[2-14 \mathrm{C}] \mathrm{MelQx}$ in Diet Comparison

Experiment

\begin{tabular}{|c|c|c|c|c|c|c|c|c|c|}
\hline $\begin{array}{l}\text { Test } \\
\text { Group/ } \\
\text { Days on Diet }\end{array}$ & $\begin{array}{l}\text { Blood } \\
(p g / g)\end{array}$ & $\begin{array}{l}\text { Heart } \\
(\mathrm{pg} / \mathrm{g})\end{array}$ & $\begin{array}{l}\text { Kichey } \\
(\mathrm{pg} / \mathrm{g})\end{array}$ & $\begin{array}{l}\text { Liver } \\
\text { (pg/g) }\end{array}$ & $\begin{array}{l}\mathrm{Lung} \\
(\mathrm{pg} / \mathrm{g})\end{array}$ & $\begin{array}{l}\text { Pancreas } \\
(\mathrm{pg} / \mathrm{g})\end{array}$ & $\begin{array}{l}\text { Solen } \\
\text { (pg/g) }\end{array}$ & $\begin{array}{l}\text { Thymus } \\
\text { (pg/g) }\end{array}$ & $\begin{array}{l}\text { Avg } \\
\text { Dose } \\
\text { (ng } \mathrm{kg} \\
\text { Day) }\end{array}$ \\
\hline $\begin{array}{l}\text { Std. Rodent } \\
\text { Chow/ } 42 \\
\text { Days }\end{array}$ & $\begin{array}{l}0.17^{a} \\
\pm 0.11\end{array}$ & $\begin{array}{l}1.97^{\mathrm{a}} \\
\pm 1.18\end{array}$ & $\begin{array}{l}0.84^{\mathrm{a}} \\
\pm 0.47\end{array}$ & $\begin{array}{l}2.01^{\mathrm{a}} \\
\pm 1.59\end{array}$ & $\begin{array}{l}1.31^{\mathrm{a}} \\
\pm 0.95\end{array}$ & $\begin{array}{l}2.35^{\mathrm{a}} \\
\pm 0.40\end{array}$ & $\begin{array}{l}0.52^{\mathrm{a}} \\
\pm 0.35\end{array}$ & $\begin{array}{l}2.04^{a} \\
\pm 1.78\end{array}$ & 0 \\
\hline $\begin{array}{l}\text { Control } \\
\text { Chow/ } 42 \\
\text { Days }\end{array}$ & $\begin{array}{l}0.24^{a} \\
\pm 0.38\end{array}$ & $\begin{array}{l}2.00^{\mathrm{a}} \\
\pm 1.61\end{array}$ & $\begin{array}{l}0.43^{a} \\
\pm 0.64\end{array}$ & $\begin{array}{l}0.41^{a} \\
\pm 0.60\end{array}$ & $\begin{array}{l}0.75^{a} \\
\pm 0.45\end{array}$ & $\begin{array}{l}0.72^{\mathrm{a}} \\
\pm 0.75\end{array}$ & $\begin{array}{l}1.72^{\mathrm{a}} \\
\pm 0.55\end{array}$ & $\begin{array}{l}2.07^{a} \\
\pm 0.41\end{array}$ & 0 \\
\hline $\begin{array}{l}\text { Test Chow' } \\
1 \text { Day }\end{array}$ & $\begin{array}{l}0.06 \\
\pm 0.09 \\
\end{array}$ & \begin{tabular}{|l|}
0.12 \\
\pm 0.15 \\
\end{tabular} & $\begin{array}{l}8.62 \\
\pm 1.27 \\
\end{array}$ & $\begin{array}{l}10.71 \\
\pm 2.34 \\
\end{array}$ & $\begin{array}{l}0.75 \\
\pm 0.05 \\
\end{array}$ & \begin{tabular}{|l|}
0.30 \\
\pm 1.85 \\
\end{tabular} & $\begin{array}{l}0.70 \\
\pm 0.29 \\
\end{array}$ & $\begin{array}{l}-0.03 \\
\pm 0.23 \\
\end{array}$ & 38.7 \\
\hline $\begin{array}{l}\text { Test Chow/ } \\
7 \text { Day }\end{array}$ & $\begin{array}{l}0.37 \\
\pm 0.25 \\
\end{array}$ & $\begin{array}{l}2.70 \\
\pm 0.28 \\
\end{array}$ & $\begin{array}{l}37.77 \\
\pm 7.68 \\
\end{array}$ & $\begin{array}{l}44.71 \\
\pm 2.63 \\
\end{array}$ & $\begin{array}{ll}1.79 \\
\pm 0.47 \\
\end{array}$ & $\begin{array}{l}2.61 \\
\pm 0.46 \\
\end{array}$ & $\begin{array}{l}3.04 \\
\pm 0.95 \\
\end{array}$ & \begin{tabular}{|l|}
1.87 \\
\pm 0.24 \\
\end{tabular} & 50.10 \\
\hline $\begin{array}{l}\text { Test Chow' } \\
14 \text { Day }\end{array}$ & $\begin{array}{l}0.52 \\
\pm 0.10\end{array}$ & $\begin{array}{l}6.82 \\
\pm 5.12\end{array}$ & $\begin{array}{l}60.92 \\
\pm 5.85\end{array}$ & $\begin{array}{l}44.89 \\
\pm 3.07\end{array}$ & $\begin{array}{l}2.75 \\
\pm 0.42\end{array}$ & \begin{tabular}{|l|}
4.43 \\
\pm 0.78
\end{tabular} & $\begin{array}{l}4.75 \\
\pm 1.53\end{array}$ & $\begin{array}{l}3.15 \\
\pm 0.90\end{array}$ & 47.59 \\
\hline $\begin{array}{l}\text { Test Chow } \\
28 \text { Day }\end{array}$ & \begin{tabular}{|l|}
1.19 \\
\pm 0.20 \\
\end{tabular} & \begin{tabular}{|l|}
9.13 \\
\pm 7.04 \\
\end{tabular} & $\begin{array}{l}77.89 \\
\pm 5.47 \\
\end{array}$ & \begin{tabular}{|l|}
58.24 \\
\pm 8.14 \\
\end{tabular} & \begin{tabular}{|l|}
4.02 \\
\pm 0.35 \\
\end{tabular} & \begin{tabular}{|l|}
5.89 \\
\pm 1.58 \\
\end{tabular} & \begin{tabular}{|l|}
6.81 \\
\pm 0.52 \\
\end{tabular} & $\begin{array}{r}0.36 \\
\pm 5.10 \\
\end{array}$ & 48.36 \\
\hline $\begin{array}{l}\text { Test Chow/ } \\
42 \text { Day }\end{array}$ & \begin{tabular}{|l|}
1.04 \\
\pm 0.05 \\
\end{tabular} & \begin{tabular}{|l|}
7.91 \\
\pm 5.10 \\
\end{tabular} & \begin{tabular}{|l|}
82.57 \\
\pm 12.24 \\
\end{tabular} & \begin{tabular}{|l|}
54.19 \\
\pm 8.43 \\
\end{tabular} & \begin{tabular}{|l|}
3.58 \\
\pm 0.27 \\
\end{tabular} & \begin{tabular}{|l|}
4.78 \\
\pm 0.88 \\
\end{tabular} & \begin{tabular}{|l|}
8.28 \\
\pm 0.94 \\
\end{tabular} & \begin{tabular}{|l|}
3.25 \\
\pm 0.21 \\
\end{tabular} & 47.50 \\
\hline $\begin{array}{l}\text { Hamburger/ } \\
\text { 1 Day }\end{array}$ & $\begin{array}{l}0.13 \\
\pm 0.07\end{array}$ & $\begin{array}{l}1.09 \\
\pm 0.72\end{array}$ & $\begin{array}{l}14.16 \\
\pm 6.27\end{array}$ & $\begin{array}{l}19.26 \\
\pm 9.82\end{array}$ & \begin{tabular}{|l|}
2.41 \\
\pm 1.22
\end{tabular} & $\begin{array}{l}0.90 \\
\pm 1.57\end{array}$ & $\begin{array}{l}1.77 \\
\pm 1.60\end{array}$ & $\begin{array}{l}0.74 \\
\pm 0.09\end{array}$ & 117.13 \\
\hline $\begin{array}{l}\text { Hamburger/ } \\
7 \text { Day }\end{array}$ & $\begin{array}{l}2.06 \\
\pm 0.72 \\
\end{array}$ & \begin{tabular}{|l|}
8.08 \\
\pm 1.86 \\
\end{tabular} & \begin{tabular}{|l|}
130.45 \\
\pm 18.32 \\
\end{tabular} & \begin{tabular}{|l|}
99.13 \\
\pm 14.86 \\
\end{tabular} & \begin{tabular}{|l|}
7.28 \\
\pm 1.71 \\
\end{tabular} & \begin{tabular}{|l|}
7.50 \\
\pm 3.10 \\
\end{tabular} & \begin{tabular}{|l|}
9.62 \\
\pm 2.23 \\
\end{tabular} & \begin{tabular}{|l|}
6.65 \\
\pm 1.96 \\
\end{tabular} & 106.5 \\
\hline $\begin{array}{l}\text { Hamburger/ } \\
14 \text { Day }\end{array}$ & $\begin{array}{l}1.92 \\
\pm 0.19 \\
\end{array}$ & $\begin{array}{r}10.10 \\
\pm 1.56 \\
\end{array}$ & $\begin{array}{r}155.15 \\
+20.40 \\
\end{array}$ & \begin{tabular}{|l|}
137.98 \\
\pm 14.99 \\
\end{tabular} & \begin{tabular}{|l|}
7.50 \\
\pm 0.94 \\
\end{tabular} & \begin{tabular}{|l|}
6.16 \\
\pm 2.80 \\
\end{tabular} & $\begin{array}{r}11.88 \\
\pm 1.18 \\
\end{array}$ & \begin{tabular}{|l|}
7.16 \\
\pm 0.83 \\
\end{tabular} & 109.99 \\
\hline $\begin{array}{l}\text { Hamburger/ } \\
28 \text { Day }\end{array}$ & $\begin{array}{l}3.25 \\
\pm 0.73 \\
\end{array}$ & $\begin{array}{r}10.42 \\
\pm 1.31 \\
\end{array}$ & $\begin{array}{r}185.05 \\
\pm 10.14 \\
\end{array}$ & $\begin{array}{r}163.63 \\
\pm 30.58 \\
\end{array}$ & $\begin{array}{l}8.66 \\
\pm 0.54 \\
\end{array}$ & $\begin{array}{l}11.11 \\
\pm 0.70 \\
\end{array}$ & $\begin{array}{l}14.11 \\
\pm 1.90 \\
\end{array}$ & $\begin{array}{l}7.98 \\
\pm 0.77 \\
\end{array}$ & 99.76 \\
\hline $\begin{array}{l}\text { Hamburger/ } \\
\text { 42 Day }\end{array}$ & $\begin{array}{l}4.14 \\
\pm 0.23\end{array}$ & $\begin{array}{l}10.74 \\
\pm 1.36 \\
\end{array}$ & $\begin{array}{r}170.40 \\
\pm 19.47 \\
\end{array}$ & $\begin{array}{r}140.00 \\
\pm 44.34 \\
\end{array}$ & $\begin{array}{l}9.49 \\
\pm 0.77 \\
\end{array}$ & \begin{tabular}{|l}
8.08 \\
\pm 6.11 \\
\end{tabular} & $\begin{array}{l}21.02 \\
\pm 3.07 \\
\end{array}$ & $\begin{array}{l}7.65 \\
\pm 1.13 \\
\end{array}$ & 96.89 \\
\hline
\end{tabular}

a Background value, animals received no known carbon-14.

Data are mean \pm standard deviation for $n=3$ rats. Measurements made by AMS. 


\section{Adjusted Chow Diet Study}

The adjusted chow feeding study was carried out after it was determined that the test chow and hamburger diets contained different levels of carbon-14. The average daily dose of [2${ }^{14} \mathrm{C}$ MelQx was $50.1,106.5$, and $117.0 \mathrm{ng} / \mathrm{kg}$ body weight for the test chow, hamburger, and adjusted chow diets respectively. The adjusted chow diet was fed to three rats for seven days to use for covariate analysis (Table 15). This dosing regime was designed so that these animals had an equivalent exposure as the rats fed the cooked hamburger diet for seven days. Also in the adjusted chow ; study, one rat that had never been given $\left[2-{ }^{14} \mathrm{C}\right] \mathrm{MelQx}$ or any of the control chows, and had been fed ad libitum, was euthanized. The tissues and DNA from that animal are listed as "not dosed," and were used as an additional comparison to check for potential carbon-14 contamination.

TABLE 15

Average Tissue levels of $[2-14 \mathrm{C}] \mathrm{MelQx}$ from the Adjusted Chow Feeding Study

\begin{tabular}{|l|l|l|l|l|l|l|l|l|l|}
\hline $\begin{array}{l}\text { Rat } \\
\text { Group }\end{array}$ & $\begin{array}{l}\text { Blood } \\
(\mathrm{pg} / \mathrm{g})\end{array}$ & $\begin{array}{l}\text { Heart } \\
(\mathrm{pg} / \mathrm{g})\end{array}$ & $\begin{array}{l}\text { Kidney } \\
(\mathrm{pg} / \mathrm{g})\end{array}$ & $\begin{array}{l}\text { Liver } \\
(\mathrm{pg} / \mathrm{g})\end{array}$ & $\begin{array}{l}\text { Lung } \\
(\mathrm{pg} / \mathrm{g})\end{array}$ & $\begin{array}{l}\text { Pancreas } \\
(\mathrm{pg} / \mathrm{g})\end{array}$ & $\begin{array}{l}\text { Spleen } \\
(\mathrm{pg} / \mathrm{g})\end{array}$ & $\begin{array}{l}\text { Thymus } \\
(\mathrm{pg} / \mathrm{g})\end{array}$ & $\begin{array}{l}\text { Avg } \\
\text { Dose/ } \\
\text { Day } \\
(\mathrm{ng} / \mathrm{kg})\end{array}$ \\
\hline Test & $\begin{array}{l}1.56 \\
\pm 0.15\end{array}$ & $\begin{array}{l}7.78 \\
\pm 74\end{array}$ & $\begin{array}{l}127.55 \\
\pm 37.88\end{array}$ & $\begin{array}{l}137.47 \\
\pm 43.89\end{array}$ & $\begin{array}{l}7.39 \\
\pm 0.28\end{array}$ & $\begin{array}{l}11.24 \\
\pm 6.11\end{array}$ & $\begin{array}{l}16.17 \\
\pm 1.90\end{array}$ & $\begin{array}{l}5.51 \\
\pm 1.49\end{array}$ & 117.02 \\
\hline $\begin{array}{l}\text { Not } \\
\text { dosed }\end{array}$ & $0.0^{\mathrm{a}}$ & $0.0^{\mathrm{a}}$ & $0.50^{\mathrm{a}}$ & $0.68^{\mathrm{a}}$ & $0.74^{\mathrm{a}}$ & $0.92^{\mathrm{a}}$ & $0.17^{\mathrm{a}}$ & $0.01^{\mathrm{a}}$ & 0 \\
\hline
\end{tabular}

a Background level, animals received no known carbon-14.

b Received no dose, nor any test or control diet associated with this study. Animal was fed standard lab chow pellets ad libitum and was isolated from test animals. Data are mean \pm standard deviation. Measurements made by AMS. 
The results from both experiments are represented graphically (Figures 7 through 14, all data points are the mean for $n=3$ animals \pm standard deviation). The graphs show the level of $[2-14 \mathrm{C}] \mathrm{MelQx}$ found in the selected tissue as a result of exposure to the hamburger diet, the test chow diet, or the adjusted chow diet at the seven day time point. The adjusted chow feeding study was done so a statistical comparison could be made using the data generated in this study as a correction factor.

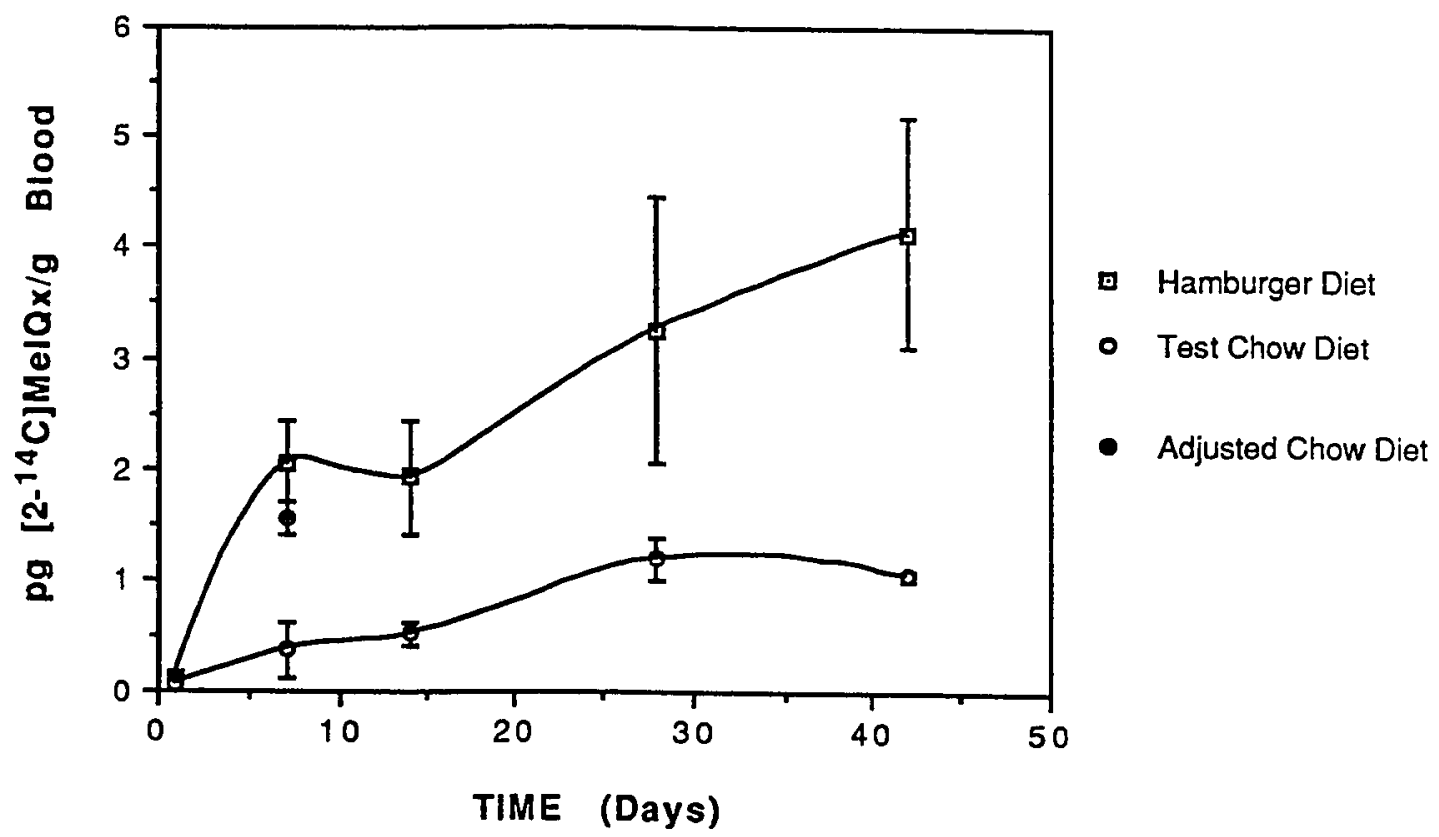

FIGURE 7. Level of MelQx in rat blood throughout a 42 day exposure period. The response in blood (Figure 7) at 7 days for the hamburger and adjusted chow are essentially equal. It appears that the concentration of $\left[2-{ }^{14} \mathrm{C}\right] \mathrm{MelQx}$ in blood has reached steady state levels for both the hamburger and test chow diets by 28 days. 


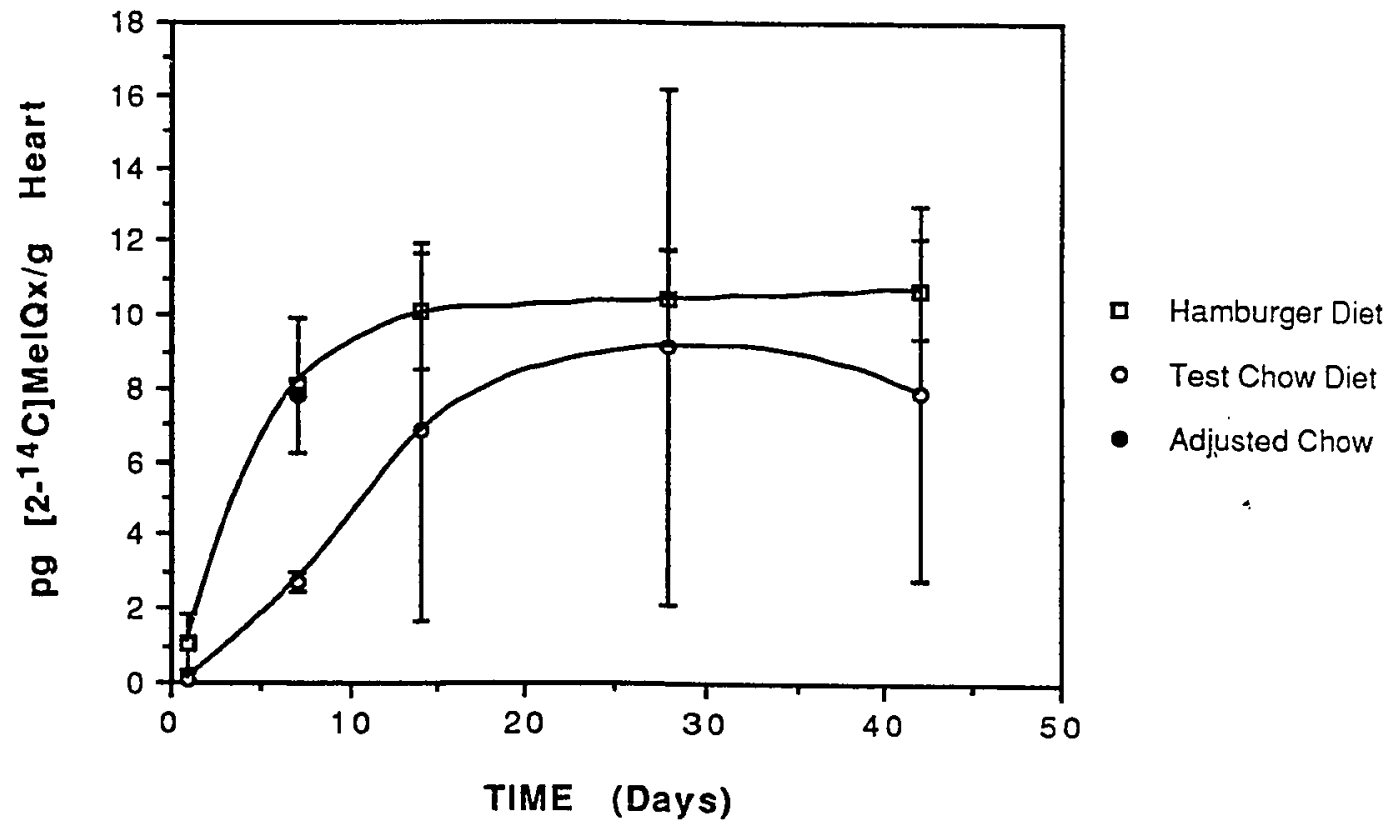

FIGURE 8. Levels of MelQx in rat heart throughout a 42 day exposure period. Similar to the trends observed in blood, MelQx attained steady state levels in the heart (Figure 8). The standard deviation seems to be high for heart tissue. 


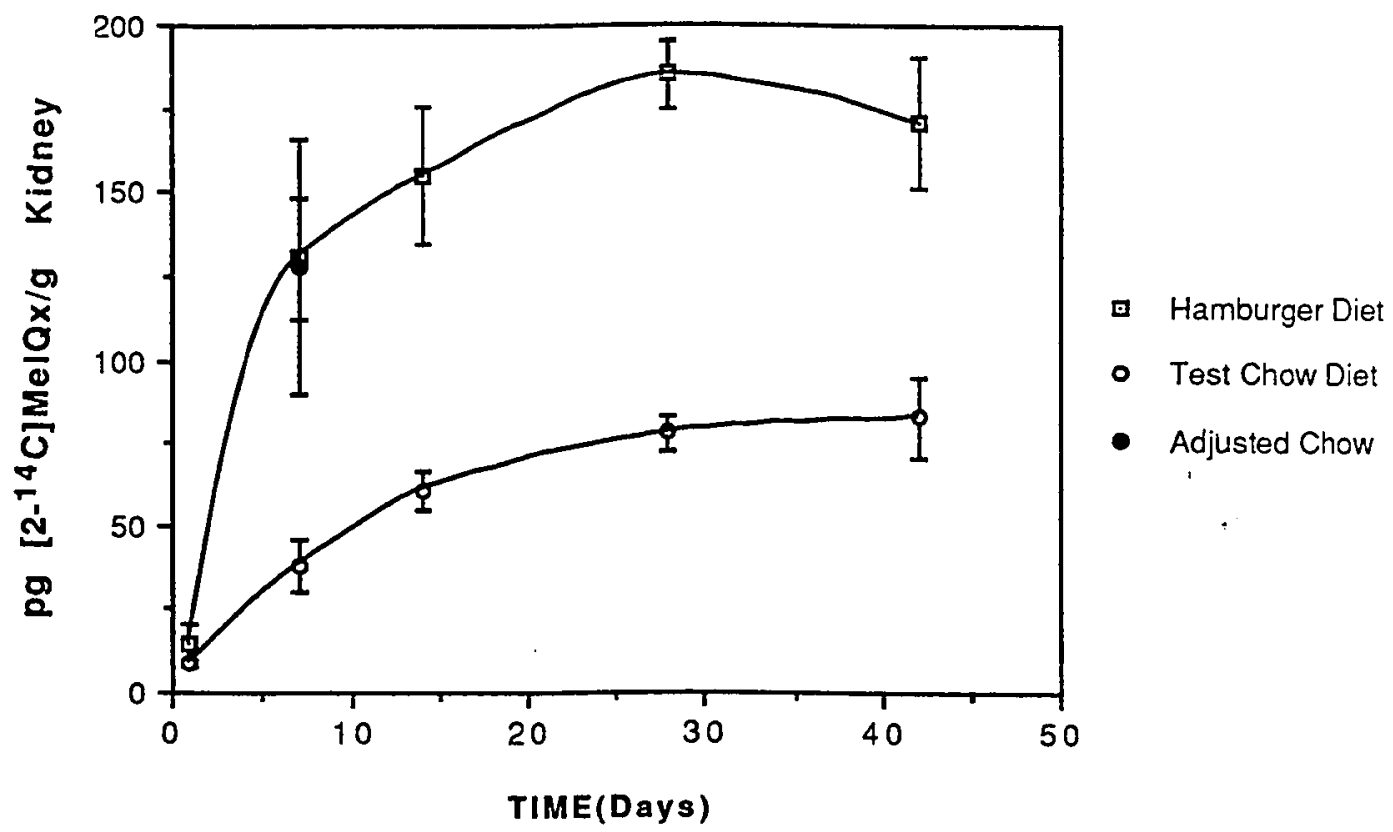

FIGURE 9. Levels of MelQx in rat kidney throughout a 42 day exposure period. The levels of $\left[2-{ }^{14} \mathrm{C}\right] \mathrm{MelQx}$ appear to reach steady state levels in the kidney (Figure 9) sooner than in blood and heart. Steady state levels begin to appear at 7 days. 


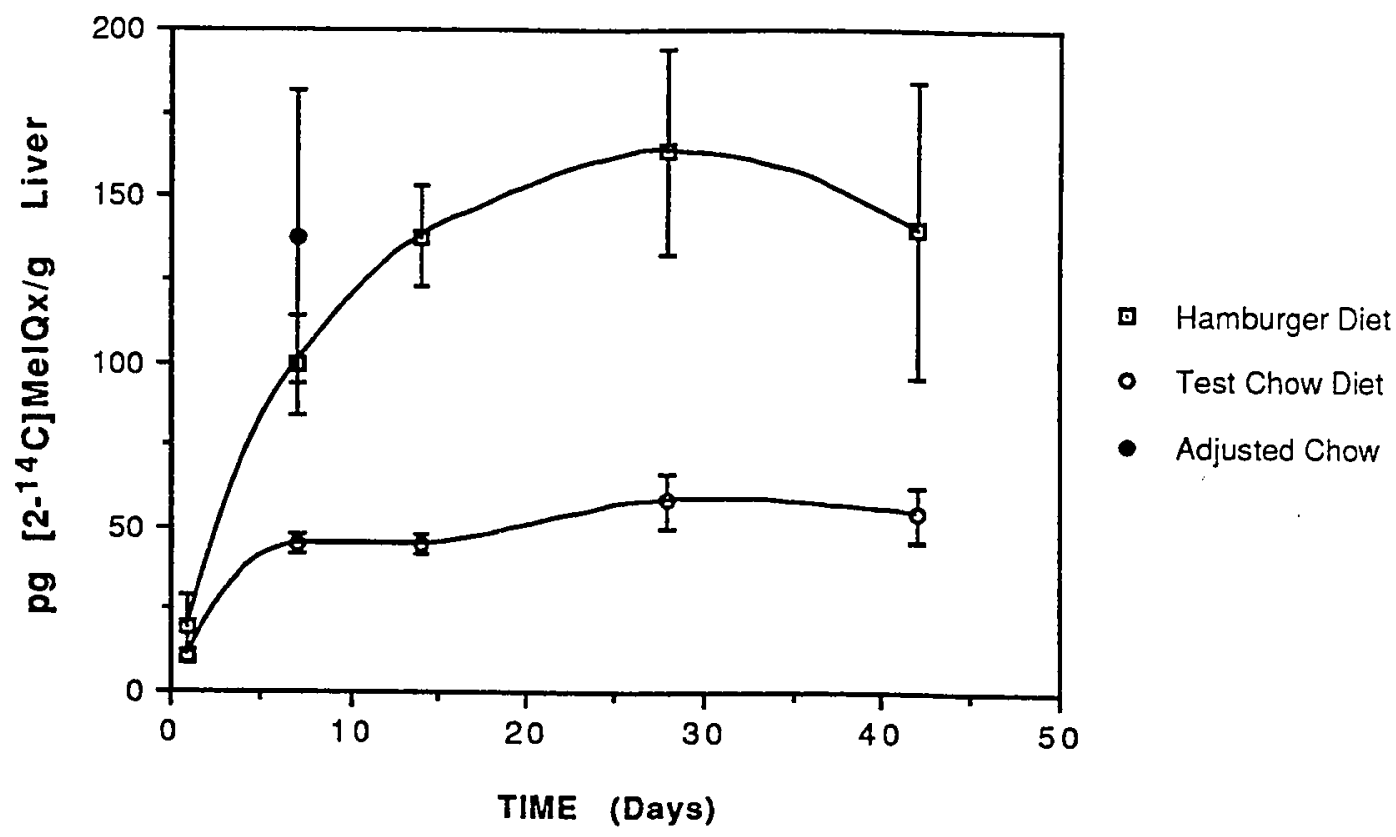

FIGURE 10. Levels of MelQx in rat liver throughout a 42 day exposure period The liver appears to reach a steady state level of $\left[2 \cdot{ }^{14} \mathrm{C}\right] \mathrm{MelQx}$ at 7 days (Figure 10). The adjusted chow diet and the hamburger diet had larger standard deviations than the test chow diet. 


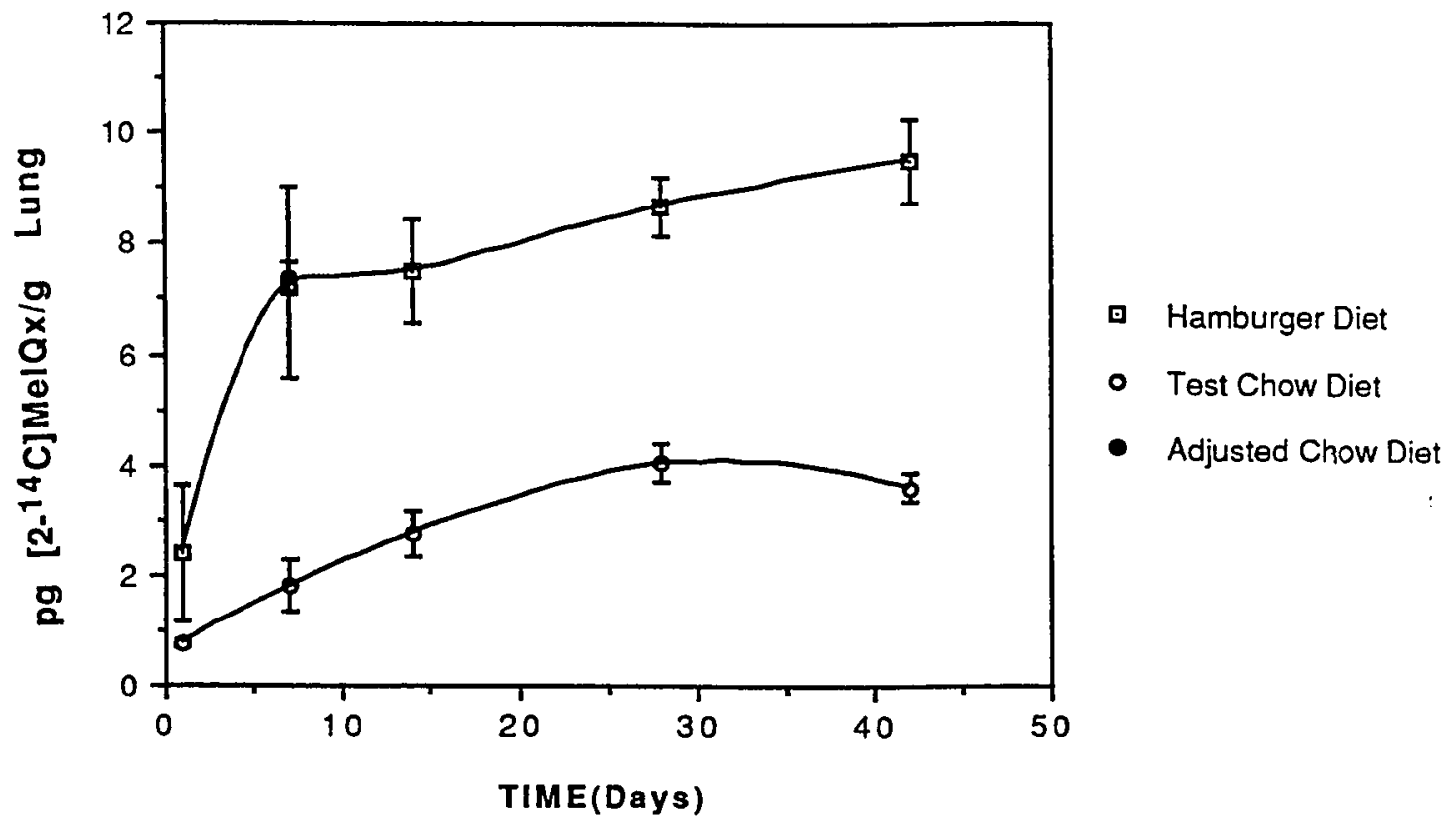

FIGURE 11. Levels of MelQx in rat lung throughout a 42 day exposure period. The steady state levels in the lung (Figure 11) appear to have been reached between 7 and 14 days. 


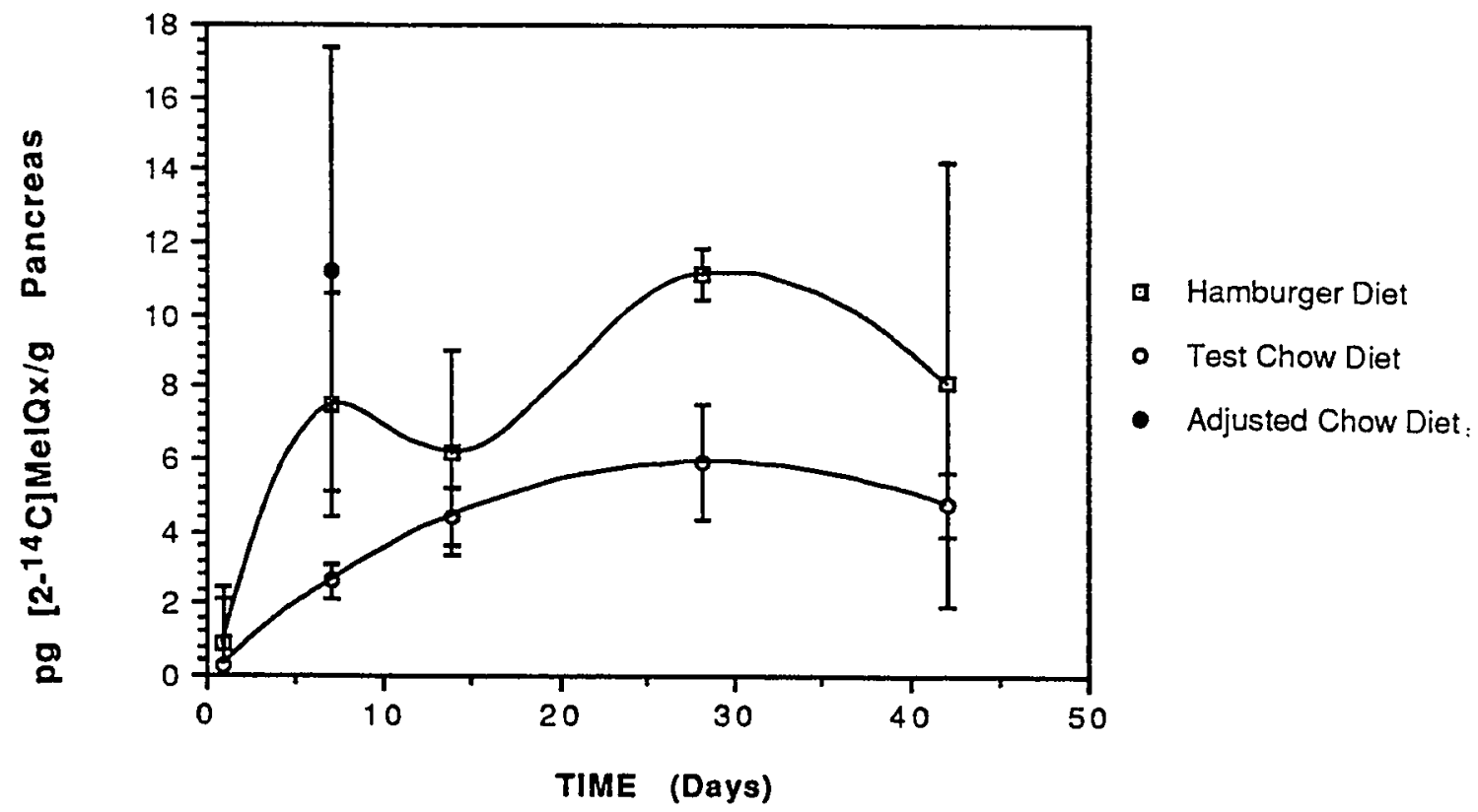

FIGURE 12. Level of MelQx in rat pancreas throughout a 42 day exposure period.

Similar to the result in all the tissues, the steady state levels were reached around 14 days in the pancreas (Figure 12). The 14 day time point for the hamburger diet appears to be low, and the adjusted chow diet appears high with a large standard deviation. 


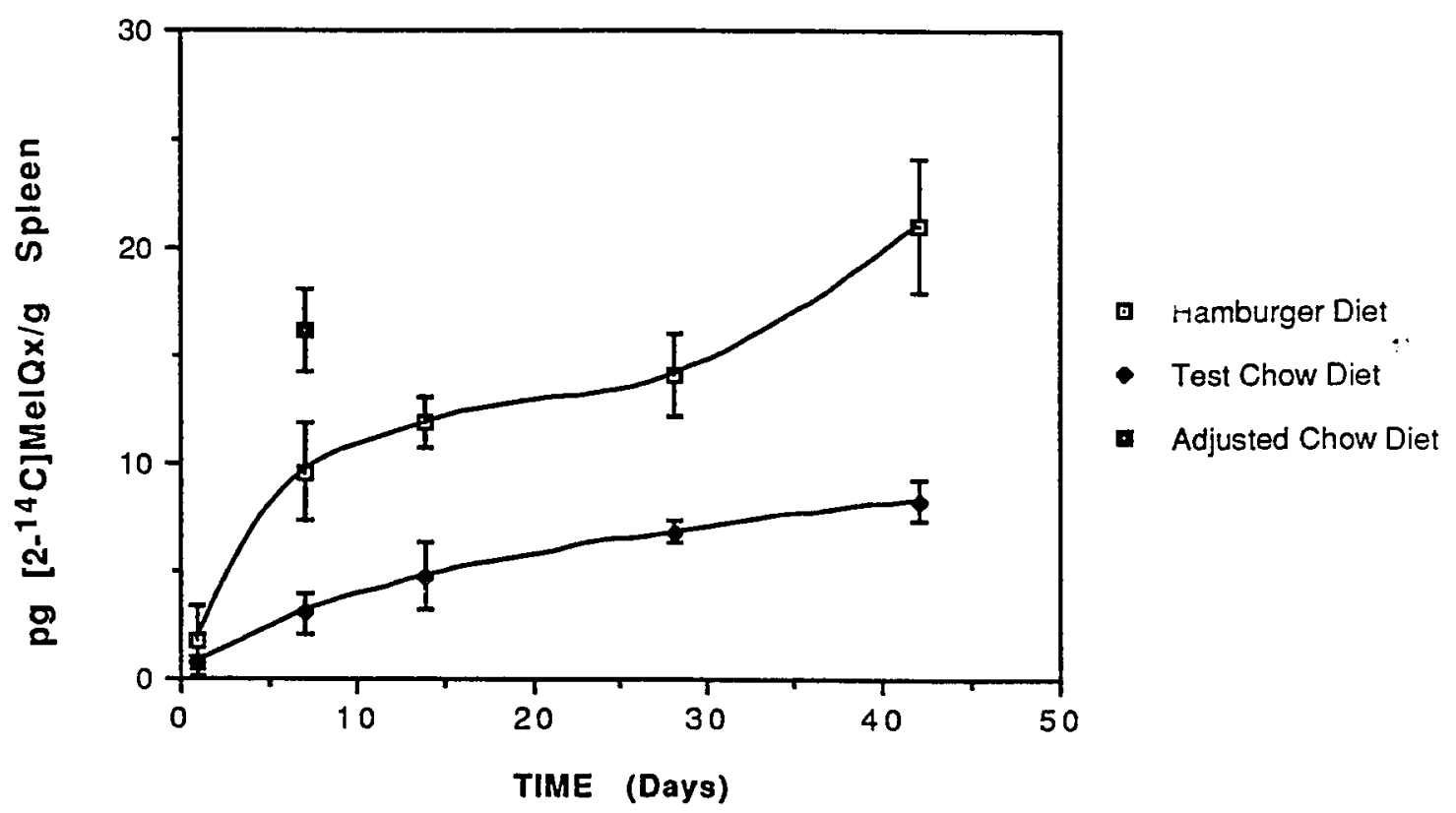

FIGURE 13. Level of MelQx in Rat Spleen throughout a 42 day Exposure Period. The 7 day time point for the spleen (Figure 13) shows the adjusted chow to be higher than the hamburger diet. 


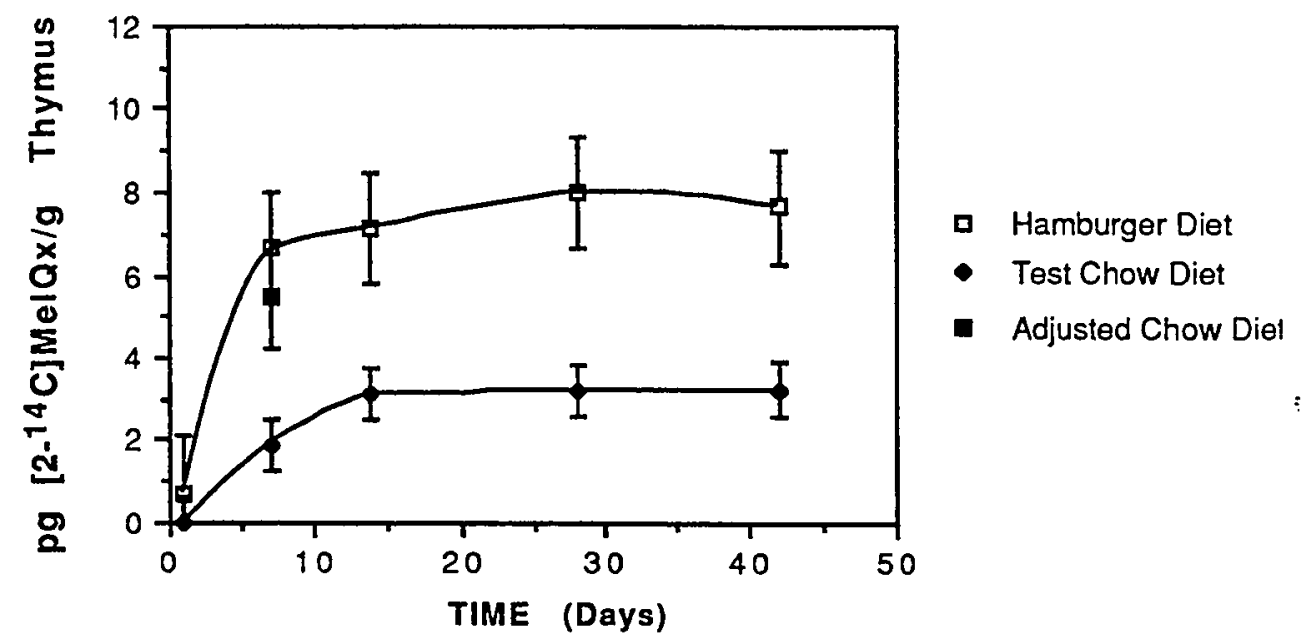

FIGURE 14. Level of MelQx in rat thymus throughout a 42 day exposure period. The steady state levels in the thymus (Figure 14) were reached at between 7 and 14 days. The error bars in this plot are the standard error of the data in order to make the error bars discernable. 


\section{DNA Binding}

No results were obtained from the feasibility study because liver DNA samples were unusable. The reason for this is that the carrier carbon used with the DNA was contaminated with carbon-14, thus making the carbon-14 associated with MelQx indistinguishable.

\section{Diet Comparison Experiment}

The levels of [2-14 C]MelQx and DNA adducts found in the liver tissue are shown in Table 16 and 17, and plotted in Figures 15 and 16.

TABLE 16

Average Rat Liver DNA levels of $[2-14 \mathrm{C}] \mathrm{MelQx}$

\begin{tabular}{|c|c|c|}
\hline TEST GROUP/ Days on Diet & pmol $\left[2 .{ }^{14} \mathrm{C}\right] \mathrm{MelQ} \times / \mathrm{g}$ DNAc & DNA Adducts/ $10^{12}$ Nucleotides \\
\hline $\begin{array}{l}\text { Standard Rodent Chow/ } \\
42 \text { Days }\end{array}$ & $47.2 \pm 40.4^{a}$ & $\ldots \ldots b$ \\
\hline Control Chow/ 42 Days & $46.9 \pm 19.7^{a}$ & $\ldots \ldots b$ \\
\hline Test Chow/ 1 Day & $31.9 \pm 3.51$ & $4.63 \pm 0.51$ \\
\hline Test Chow 7 Days & $27.7 \pm 23.19$ & $4.02 \pm 3.36$ \\
\hline Test Chow/ 14 Days & $27.8 \pm 20.4$ & $4.02 \pm 2.96$ \\
\hline Test Chow/ 28 Days & $24.8 \pm 17.3$ & $3.59 \pm 2.51$ \\
\hline Test Chow/ 42 Days & $96.5 \pm 31.4$ & $13.98 \pm 4.56$ \\
\hline Hamburger/1 Day & $13.5 \pm 1.63$ & $1.98 \pm 0.24$ \\
\hline Hamburger/7 Days & $38.3 \pm 0.51$ & $5.56 \pm 0.07$ \\
\hline Hamburger/14 Days & $64.6 \pm 5.98$ & $9.36 \pm 0.87$ \\
\hline Hamburger/28 Days & $113.0 \pm 9.54$ & $16.38 \pm 1.38$ \\
\hline Hamburger/42 Days & $100.9 \pm 50.4$ & $14.62 \pm 7.31$ \\
\hline
\end{tabular}

a Background level, animals received no known ${ }^{14} \mathrm{C}$.

bAssumption made that no adducts formed.

c Carrier carbon was used in the measurement of this DNA.

Data are mean \pm standard deviation for $n=3$ rats. Measurements done by AMS. 
TABLE 17

DNA levels of $\left[2-{ }^{14} \mathrm{C}\right] \mathrm{MelQx}$ from the Adjusted Chow Feeding Study

\begin{tabular}{|l|l|l|}
\hline $\begin{array}{l}\text { Rat } \\
\text { Group }\end{array}$ & $\begin{array}{l}\text { DNA } \\
\text { pg/g DNA }\end{array}$ & $\begin{array}{l}\text { Adducts/ 1012 } \\
\text { Nucleotides }\end{array}$ \\
\hline Test & $2.2 \pm 0.8$ & $0.3 \pm 0.1$ \\
\hline Coldc & $0.65^{b}$ & N.D.d \\
\hline
\end{tabular}

a Carrier carbon was used in these measurements

b Background level, animals received no known carbon-14.

c Received no dose, nor any test or control diet associated with this study. Animal was fed standard lab chow pellets ad libitum and was isolated from test animals.

Data are mean \pm standard deviation of $n=3$ rats, 1 determination each for the test group and an $n=1$ for the "cold"group.

d Not detectable. 


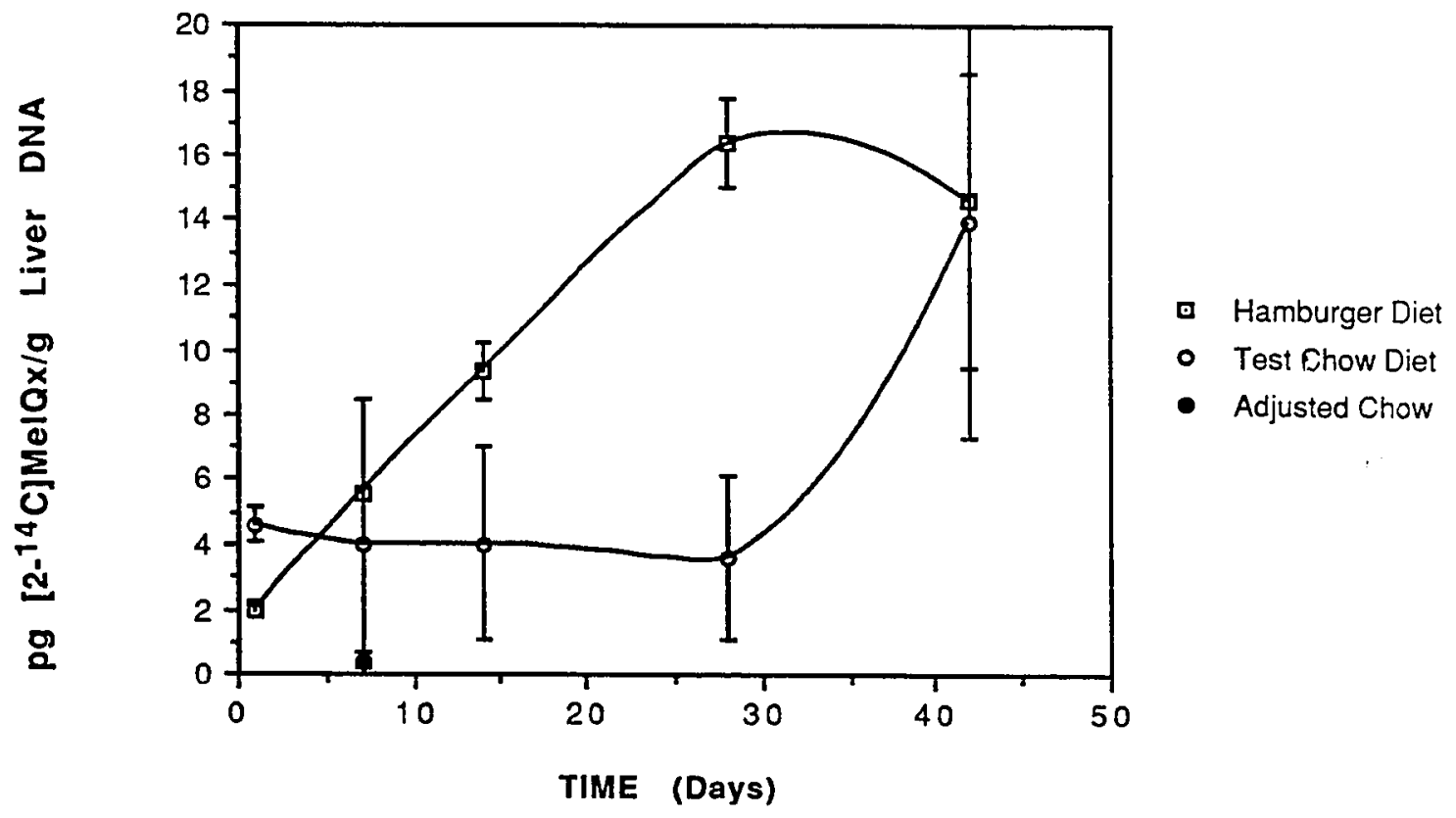

FIGURE 15. Level of $\left[2-{ }^{14} \mathrm{C}\right] \mathrm{MelQx}$ in rat liver DNA throughout a 42 day exposure period. The adduct levels in the DNA (Figure 15) For hamburger, chow, and adjusted chow diets do not appear to reach a steady state over the 42 day exposure period. The adjusted chow diet produced lower adduct levels than the test chow diet. 


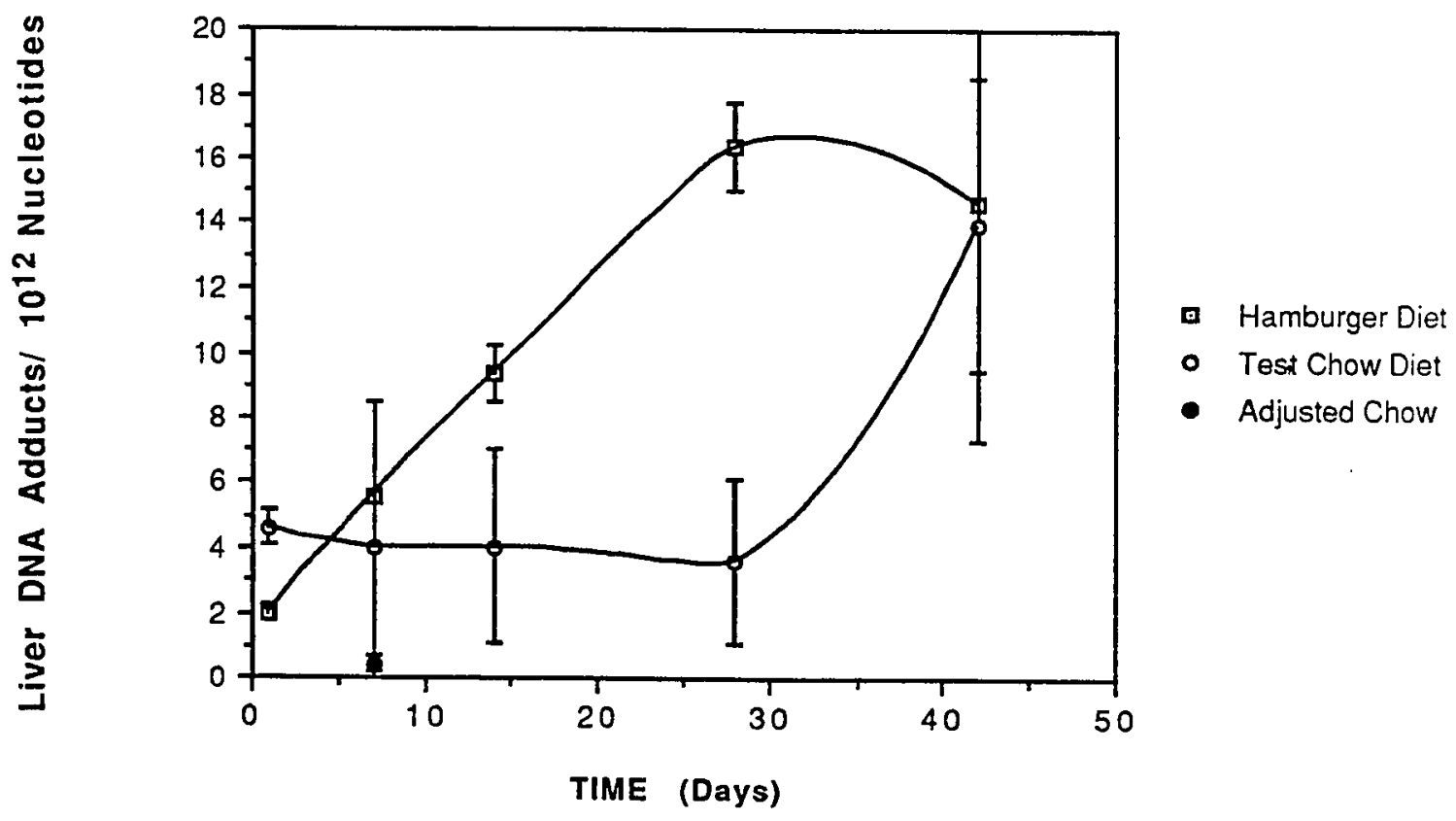

FIGURE 16. MelQx adducts in rat liver DNA. 


\section{Statistical Analysis}

Using analysis of variance it was determined that dose, not diet, was the significant factor effecting tissue levels of [2$\left.{ }^{14} \mathrm{C}\right] \mathrm{Mel} Q \mathrm{x}$ in all rat tissues at the seven day time point $(p \leq 0.05)$. After completion of the seven day study to determine an adjustment factor, analysis of variance (ANOVA) was used to determine whether diet or dose caused a significant difference at the seven day time point. This was done at the 7 day time point by comparing the hamburger diet at the high dose, the test chow diet at the low dose, and the adjusted chow diet at the high dose. The p-values for each tissue from ANOVA analysis are listed in Table 19. At the seven day time point, the dose was determined to be the significant factor, and diet was determined not to be significant except in the case of the spleen. The ANOVA tables for each tissue are in Appendix 2

\section{TABLE 18}

P-Values

\begin{tabular}{|l|l|l|l|l|l|l|l|l|l|}
\hline $\begin{array}{l}\text { Source/ } \\
\text { Tissue }\end{array}$ & Blood & Heart & Kidney & Liver & Lung & Pancreas & Spleen & Thymus & $\begin{array}{l}\text { Liver } \\
\text { DNA }\end{array}$ \\
\hline Diet & 0.2224 & 0.7661 & 0.8906 & 0.1303 & 0.8978 & .2925 & 0.0040 & .3653 & $\mathrm{a}$ \\
\hline Dose & 0.0174 & 0.0018 & 0.0043 & 0.0054 & 0.0006 & 0.0373 & 0.0001 & .0207 & $\mathrm{a}$ \\
\hline
\end{tabular}

a Not performed, see discussion section. The p-values were obtained through analysis of variance

Dose was a significant factor in determining tissue levels of MelQx for all organs examined. The spleen was unusual in that both dose and diet were statistically significant. The statistical results seen in the spleen do not agree with the results seen in the other tissues, and thus do not make biological sense. The statistical analysis was used to normalize the test chow dose response values, for comparison to the hamburger dose response values (see Discussion section) by using an additive value for each sample type, i.e. heart, DNA, liver all had a different additive corrective values. 
The absolute value of the difference between the adjusted chow diet dose response (pg $[2-14 \mathrm{C}] \mathrm{MelQx} / \mathrm{g}$ tissue) and the test chow dose response (pg $[2-14 \mathrm{C}] \mathrm{MelQx} / \mathrm{g}$ tissue) at each tissue was determined. This was used as an additive value to normalize all test chow low dose response values $\left(\mathrm{pg}\left[2-{ }^{14} \mathrm{C}\right] \mathrm{MelQx} / \mathrm{g}\right.$ tissue). The additive method was compared to another method, the percentage increase method for fit at all the time points. The additive method most closely predicted for all time points what was seen at the seven day time point. The tissue levels of $\left[2-{ }^{14} \mathrm{C}\right] \mathrm{MelQ}$ x of rats fed a chow diet that contained the same level of $\left[2-{ }^{14} \mathrm{C}\right] \mathrm{MelQx}$ as the hamburger diet were compared to tissue levels of rats fed the hamburger diet. The: response in rats fed the test chow was normalized for comparison to the dose response that resulted from feeding rats the hamburger diet. 


\section{DISCUSSION}

The initial question asked in this thesis was: what effect does diet exert on tissue levels and DNA adducts in rats exposed to human equivalent doses of MelQx? The results show that after seven days of exposure the effect of the two diets used in this study was not significant, and that dose was the significant factor in tissue levels and DNA adducts caused by exposure to $\left[2-{ }^{14} \mathrm{C}\right] \mathrm{MelQx}$.

\section{Feasibility Study}

Before discussing the results of the diet comparison experiment, the feasibility study deserves examination. The feasibility study was done to answer several questions. Is a human equivalent dose of carbon-14 labeled MelQx fed to rats measurable in a sub-chronic study ? Will rats eat a non-traditional diet i.e. hamburger, and still be in good health ? Is the use of a restriction diet an effective means of conducting this feeding study ? 
The data taken from the feasibility showed that the experimental dosage was valid. The rats ate raw hamburger spiked with a known level of $\left[2-{ }^{14} \mathrm{C}\right] \mathrm{MelQx}$, however, the rats developed diarrhea when fed hamburger alone, and this was resolved by feeding them standard rodent chow in addition to the hamburger. The restriction diet dosing regime was found appropriate, and by feeding rats only the number of kilocalories required each day, and not ad libitum, the rats would eat all the food given to them. The only food the rats did not eat was the food they dropped through the bottom of their hanging screen cages and this was recorded each day. The tissue levels of $[2-14 \mathrm{C}] \mathrm{MelQx}$ were measurable by accelerator mass spectrometry when the rats were exposed to human equivalent levels of MelQx. In addition to exposing rats to human equivalent levels of MelQx, a new method for isolating genomic DNA was developed in order to minimize carbon-14 contamination of the DNA during isolation. These steps were all necessary prior to beginning the diet comparison study.

Another interesting finding of the initial study was the possible effect the spiked hamburger had on rat body weight. This could not be determined positively because the rats were not randomized prior to beginning the study. If there was no bias in assigning rats to their experimental groups, then rats fed raw hamburger weighed more $(20 \%)$ at the end of 42 days, than rats fed the same amount of hamburger, but which had acid water, and [2${ }^{14} \mathrm{CJMelQx}$ added. A similar result was seen by Kato et al. (6) in a rat carcinogenicity study, although the dose of MelQx was higher, 400 ppm in food given ad libitum. 
During the feasibility study the male Sprague-Dawley rats received $59 \mathrm{ng}$ of $[2-14 \mathrm{C}] \mathrm{MelQx}$ daily. This corresponds to a daily dose of 189 to $223 \mathrm{ng} / \mathrm{kg}$ each day. MelQx is found in fried ground beef at levels between 1.3 to $2.4 \mathrm{ng} / \mathrm{g} \mathrm{(5).} \mathrm{A} 70 \mathrm{~kg}$ person would have to eat between 5.5 to $12.0 \mathrm{~kg}$ of cooked fried beef each day for an equivalent exposure. While this is on the high end of human exposure it is certainly possible. The level of MelQx in the hamburger was $2.95 \mathrm{ng} / \mathrm{g}$ or $3 \mathrm{ppb}$ given to rats on a restricted basis. In contrast, in the carcinogenicity study by Kato et al. the dose was $0.04 \% \mathrm{MelQx}$ in the diet fed ad libitum. Their level is at least a factor of $10^{5}$ higher in dose than was fed to the rats in the feasibility experiment in these studies. The male rats in the carcinogenicity study by Kato et al (6), were fed $400 \mathrm{ppm}$ MelQx for an average of 326 days. In rats surviving 177 days or more, tumors were seen in the liver, zymbal gland, and skin. None of the rats in the 42 day low dose study developed any tumors. 
The levels of $[2-14 \mathrm{C}] \mathrm{MelQx}$ were measured in the liver, heart, thymus, and liver DNA. The tissues measured all reached a steady state within the 42 day study.

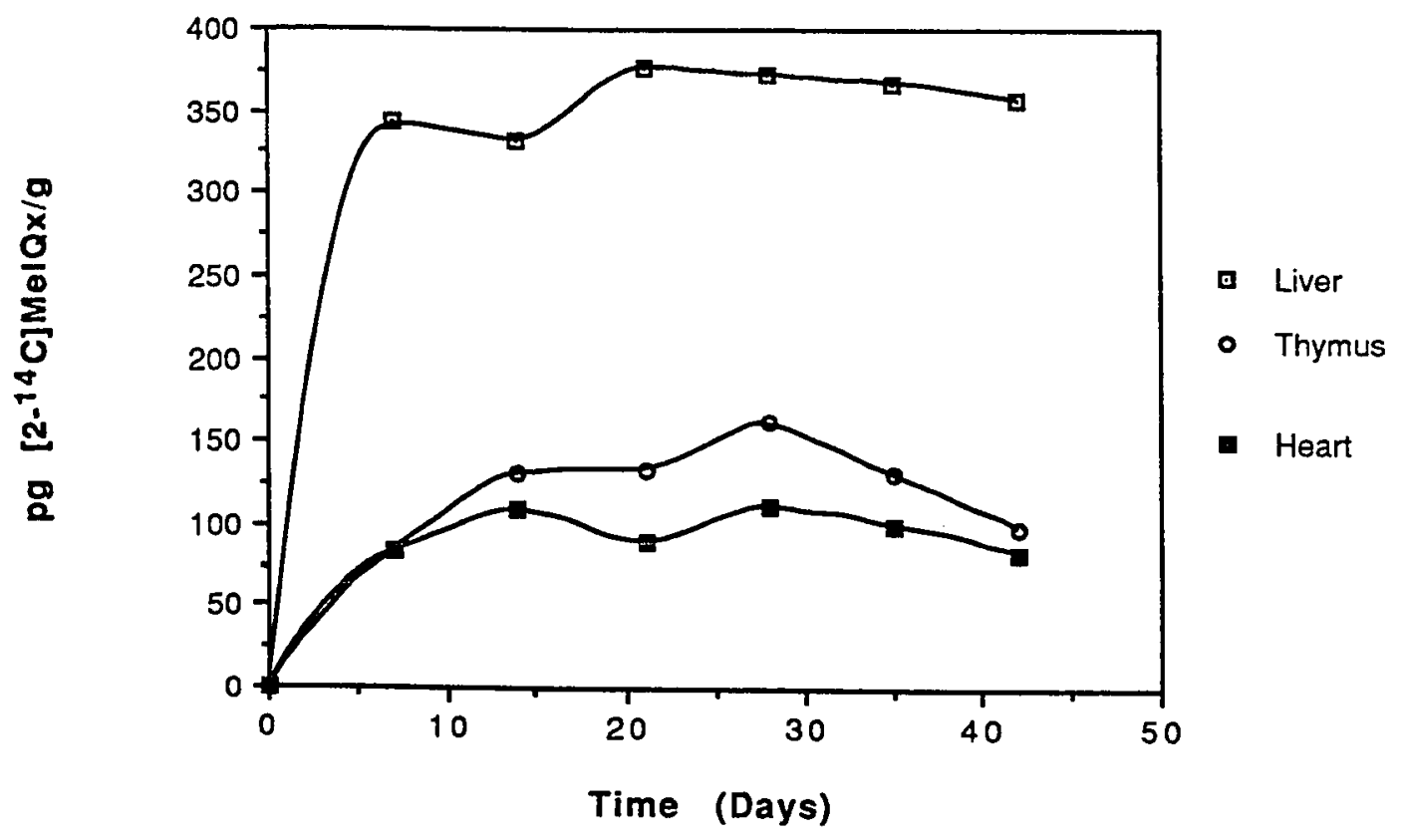

FIGURE 17. Tissue levels of $\left[2-{ }^{14} \mathrm{C}\right] \mathrm{MelQx}$ in rat tissues from the feasibility experiment. In Figure 17, time 0 are the controls, which were fed hamburger with no $\left[2-{ }^{14} \mathrm{C}\right] \mathrm{MelQx}$ for 42 days. Each time point is the average of the tissues from 2 rats. 
It was interesting to see that the level of $\left[2-{ }^{-14} \mathrm{C}\right] \mathrm{Me} / \mathrm{Qx}$ reached a constant level by seven days. The achievement of a steadystate of $\left[2-{ }^{-14} \mathrm{C}\right] \mathrm{MelQ} x$ in the tissues was not unexpected. When a constant dose is given to an animal over time a steady state level is often achieved (43). The time that it takes to reach the steadystate depends on the absorbed dose, bioavailability, metabolism, absorption kinetics, and volume of distribution (43). Of the three tissues measured, the levels in liver were much higher than the either the levels achieved in the heart or thymus. This is not surprising, since most compounds that are ingested are absorbed into the blood supply of the gastrointestinal tract, and most of this blood goes directly into the liver where the compound can first be absorbed and metabolized. Since the liver is the first site of metabolism, the primary site of xenobiotic metabolism, and rats have had a high incidence of liver tumors in the carcinogenesis studies (6), it was expected to see a higher concentration of [2${ }^{14} \mathrm{CJMelQx}$ in the liver than in most other organs. The concentration of $\left[2-{ }^{14} \mathrm{C}\right] \mathrm{MelQx}$ in the heart and thymus reached similar steadystate levels indicating that at these two organs had similar absorption kinetics of the compound from the plasma into the organ compartment. 


\section{Diet Comparison Experiment}

The diet comparison experiment, which also involved a seven day feeding study with an adjusted diet, yielded many interesting results. First it addressed the primary question posed in this thesis, i.e. does diet have an effect on tissue and DNA adduct levels in rats chronically exposed to $[2-14 \mathrm{C}] \mathrm{MelQx}$ at a human dietary equivalent dose? The two diets fed to the rats in the diet comparison experiment did not effect the tissue levels of MelQx in young male Sprague-Dawley rats at the seven day time point. Initially the diet comparison was supposed to span 42 days, but the analysis of the diets showed that the first laboratory chow diet contained a level of $[2-14 \mathrm{C}] \mathrm{MelQx}$ that was lower than the cooked hamburger diet, making a direct comparison of dietary effect impossible. In order to adjust the laboratory chow diet response in the rat, a second laboratory chow diet was spiked with $[2-14 \mathrm{C}] \mathrm{MelQx}$ at a level to equal the rats exposure via the hamburger diet. The rats were fed this diet for seven days. By combining all the dose response data at the seven day time point and using analysis of variance, it was suggested that the dose, not the diet was the significant cause of the measured $\left[2-{ }^{14} \mathrm{C}\right] \mathrm{MelQx}$ levels in the rat tissues. 
The results of the tissue measurements reported in Table 14 show the level of $\left[2-{ }^{14} \mathrm{C}\right] \mathrm{MelQ} x$ found in the test tissues. When these values can be compared to the control tissues, some of the control tissue are elevated, which is probably due to slight contamination by carbon-14 during sample preparation. The level of contamination is well below the steady state levels achieved in all the tissues within the 42 day study. This shows that the measurements and the conclusions of reaching a steady state level are valid. The levels of $\left[2-{ }^{14} \mathrm{C}\right] \mathrm{MelQx}$ are similar in the kidney and liver where, as previously discussed, absorption and excretion are occurring. The remainder of the tissues have comparable levels of $\left[2-{ }^{14} \mathrm{C}\right] \mathrm{MelQx}$, indicating that these tissues all have similar absorption kinetics, varying by their extent of perfusion. This result is similar to what was seen in the feasibility experiment.

\section{Dose Comparison to Human Exposure}

The average dose levels of $[2-14 \mathrm{C}] \mathrm{MelQx}$ for the test chow diet was $46 \mathrm{ng} / \mathrm{kg} / \mathrm{day}$, for a $70 \mathrm{~kg}$ human this translates to between 1.3 and $2.5 \mathrm{~kg}$ of fried ground beef a day (5). The average dose levels of $[2-14 \mathrm{C}] \mathrm{MelQx}$ for the adjusted chow diet and the cooked hamburger was $117 \mathrm{ng} / \mathrm{kg} /$ day and $106 \mathrm{ng} / \mathrm{kg} /$ day respectively. This translates into between 3.1 and $6.3 \mathrm{~kg}$ of fried ground beef a day for a $70 \mathrm{~kg}$ human (5). Caution must still be used both when considering equivalent exposures and extrapolating animal results to humans. 


\section{Extrapolation of Dose Response}

When the cause of the difference seen between the lab chow and hamburger diets in the 42 day diet comparison study was determined, the next task was to adjust the 42 day lab chow fed rats tissue levels, and this was done by using the results of the statistical analysis. Several different methods of adjustment were examined, using the assumption that the tissue levels should be equal for the two different diets. This assumption was based on results seen at seven days by feeding rats $\left[2-{ }^{-14} \mathrm{C}\right] \mathrm{MelQx}$ in hamburger and by feeding rats an equal dose of $[2-14 \mathrm{C}] \mathrm{Mel} Q \mathrm{x}$ in lab chow. The response in the rats were equal in all the tissues, except the spleen, in which the level of $\left[2-{ }^{14} \mathrm{C}\right] \mathrm{MelQx}$ was slightly higher in the adjusted chow fed rats. The results seen in the spleen did not agree with what was seen in all the other tissues, possibly due to animal variability or random carbon-14 contamination. The results seen in the spleen and some of the large standard deviations seen in the ANOVA are probably caused by some combination of the aforementioned causes. The large standard deviations and the anamolous results in the spleen are most likely not due to errors in the accelerator mass spectrometer. This is because each individual AMS sample result is the mean of 3 or more AMS measurements of that individual sample. If for some reason individual sample measurements did not agree, then the instrument might be suspected, but in these studies, there was very good agreement among individual samples.

With the knowledge that the results can be considered reliable, and that the two diets produced equal responses in rats at seven days, it was assumed that the same response should be seen at each time point of the sub chronic study. 
Prior to applying this assumption several questions had to be answered. Could the dose response relationship between the diet and the measured tissue levels change? How could it change? Would it be expected to change? From examination of the data the tissue levels can be expected to rise after seven days, however the tissue levels of $[2-14 \mathrm{C}] \mathrm{MelQx}$ rise slowly within the 42 day study, so no quick or unexpected changes in tissue levels should be expected. Based on the observation that the diet does not effect the tissue levels at seven days, it can be reasonably assumed that the diet should not be a factor at any of the time points.

Using these assumptions, an adjustment factor was developed. The adjustment needed to be based on difference in dose or response. The adjustment that resulted in the chow fed rat tissue levels most closely matching the tissue levels in the hamburger fed rats was an additive adjustment. The difference in $[2-14 \mathrm{C}] \mathrm{MelQx}$ levels in rats fed the chow diet with the lower dose and the higher dose was the adjustment value and this the difference, seen at seven days, was added to the $1,14,28$, and 42 day time points of the response in rats fed the laboratory chow that contained $0.6 \mathrm{ng} / \mathrm{g}[2-14 \mathrm{C}] \mathrm{MelQx}$. Then these adjusted responses to the actual responses seen by feeding the rats the hamburger diet. The expected response were compared resulting from a higher dose in rats fed laboratory chow is compared to the actual response seen in rats fed the hamburger diet for each tissue (Figures 18 through 25). 
Predicted Chow Diet

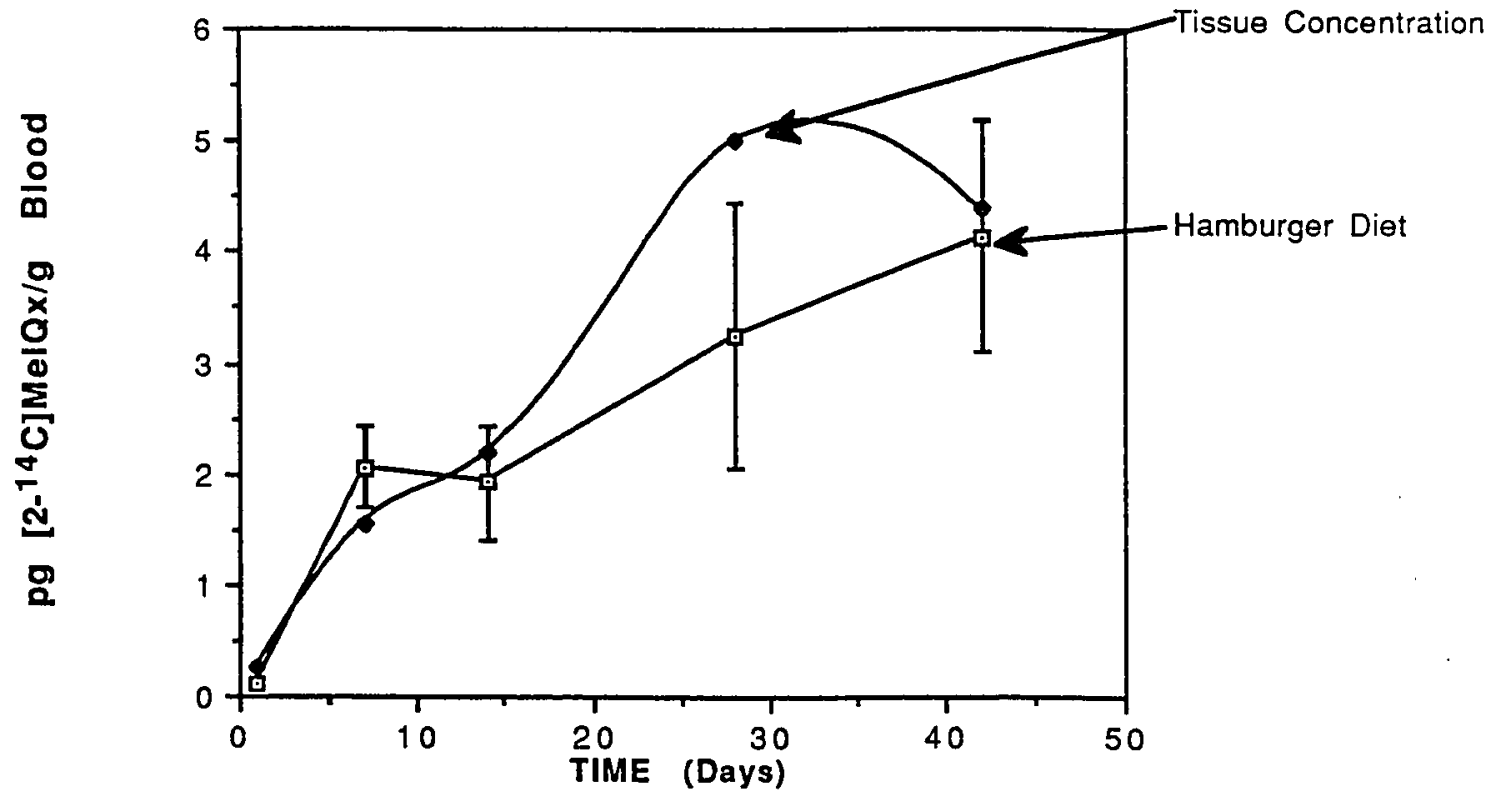

FIGURE 18. Comparison of actual response from dose in hamburger and predicted response from dose in chow in rat blood. The difference in blood $\left[2-{ }^{14} \mathrm{C}\right] \mathrm{MelQx}$ levels as a result of exposure to the low laboratory chow dose [47 $\mathrm{ng} / \mathrm{kg} /$ day] and the higher laboratory chow dose [117 ng/kg/day] was $1.187 \mathrm{pg} / \mathrm{g}$ blood. In Figure $18,1.187 \mathrm{pg}$ was added to each low chow time point response to arrive at the predicted chow diet blood tissue concentration. 


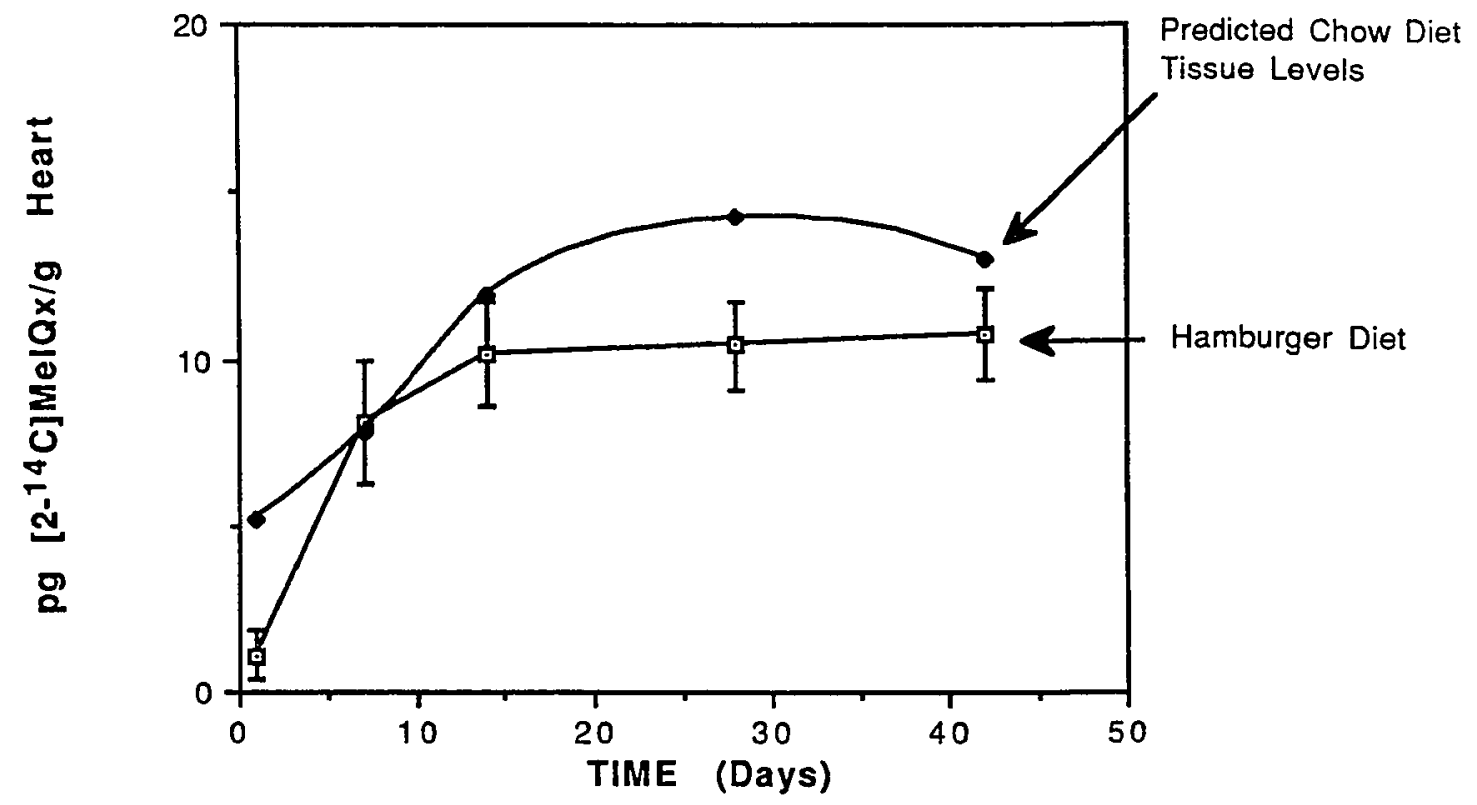

FIGURE 19. Comparison of actual response from dose in hamburger and predicted response from dose in chow in rat heart tissue. The difference in heart $[2-14 \mathrm{C}] \mathrm{MelQx}$ levels as a result of exposure to the low laboratory chow dose $[47 \mathrm{ng} / \mathrm{kg} / \mathrm{day}]$ and the higher laboratory chow dose [117 ng/kg/day] was $5.083 \mathrm{pg} / \mathrm{g}$ heart In Figure 19, $5.083 \mathrm{pg}$ was added to each low chow time point response to arrive at the predicted chow diet heart tissue concentration. 


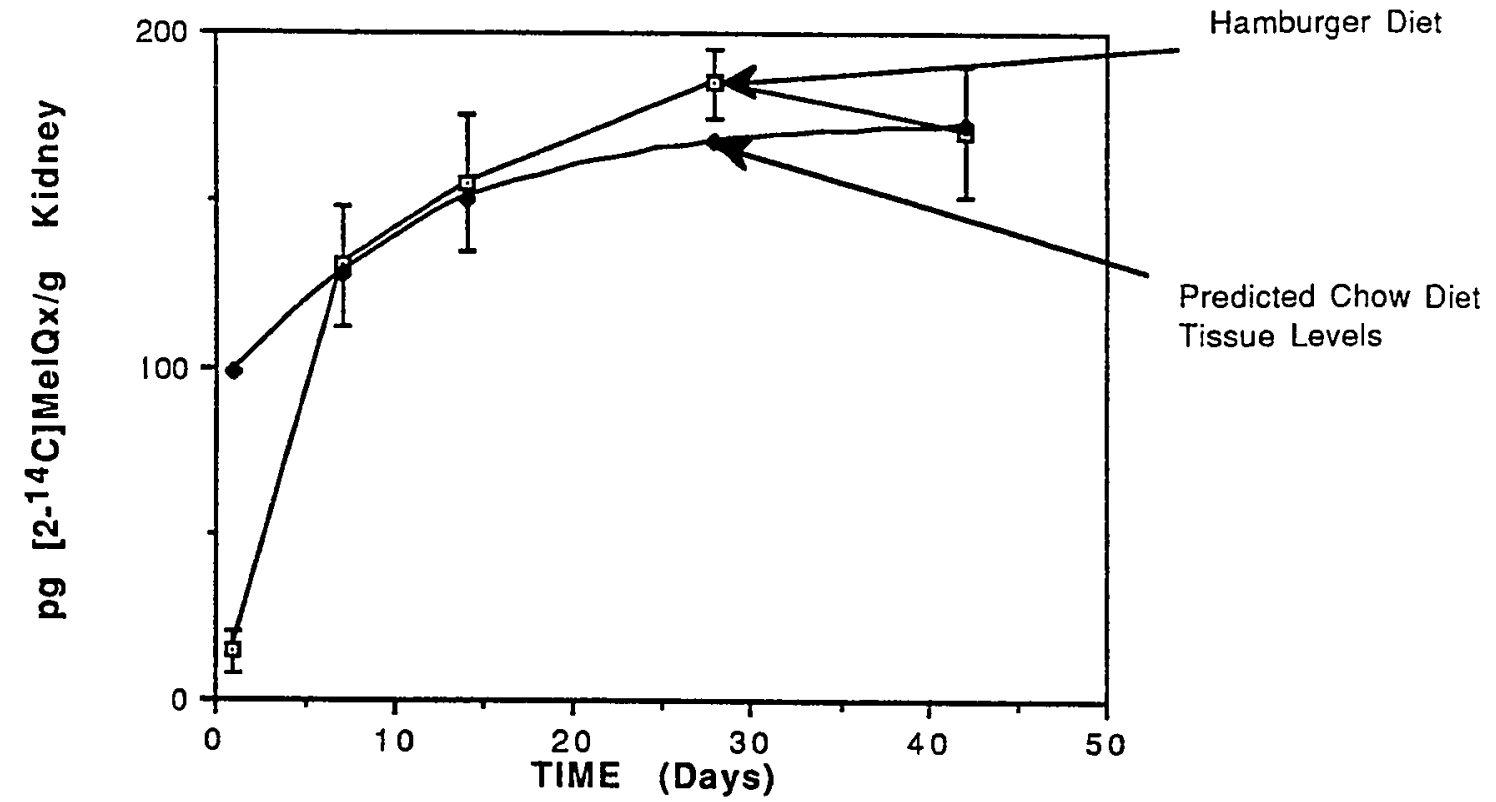

FIGURE 20. Comparison of actual response from dose in hamburger and predicted response from dose in chow in rat kidney tissue. The difference in kidney [2-14 C]MelQx levels as a result of exposure to the low laboratory chow dose [47 ng/kg/day] and the higher laboratory chow dose [117 ng/kg/day] was $89.79 \mathrm{pg} / \mathrm{g}$ kidney. In Figure 20, $89.79 \mathrm{pg}$ was added to each low chow time point response to arrive at the predicted chow diet kidney tissue concentration. 


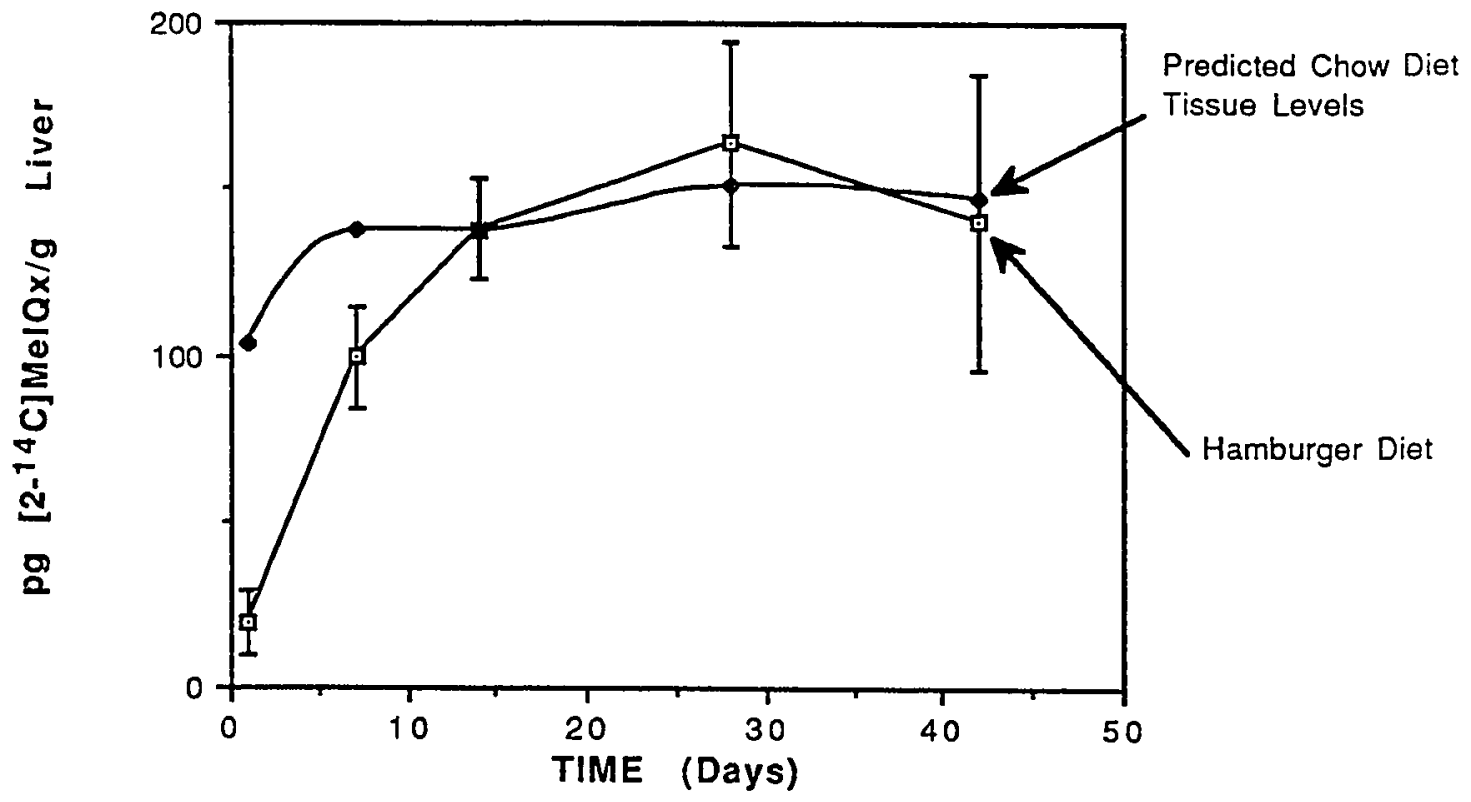

FIGURE 21. Comparison of actual response from dose in hamburger and predicted response from dose in chow in rat liver tissue. The difference in liver $\left[2-{ }^{14} \mathrm{C}\right] \mathrm{MelQx}$ levels as a result of exposure to the low laboratory chow dose [47 ng/kg/day] and the higher laboratory chow dose [117 ng/kg/day] was $92.753 \mathrm{pg} / \mathrm{g}$ liver. In Figure 21, $92.753 \mathrm{pg}$ was added to each low chow time point response to arrive at the predicted chow diet liver tissue concentration. 


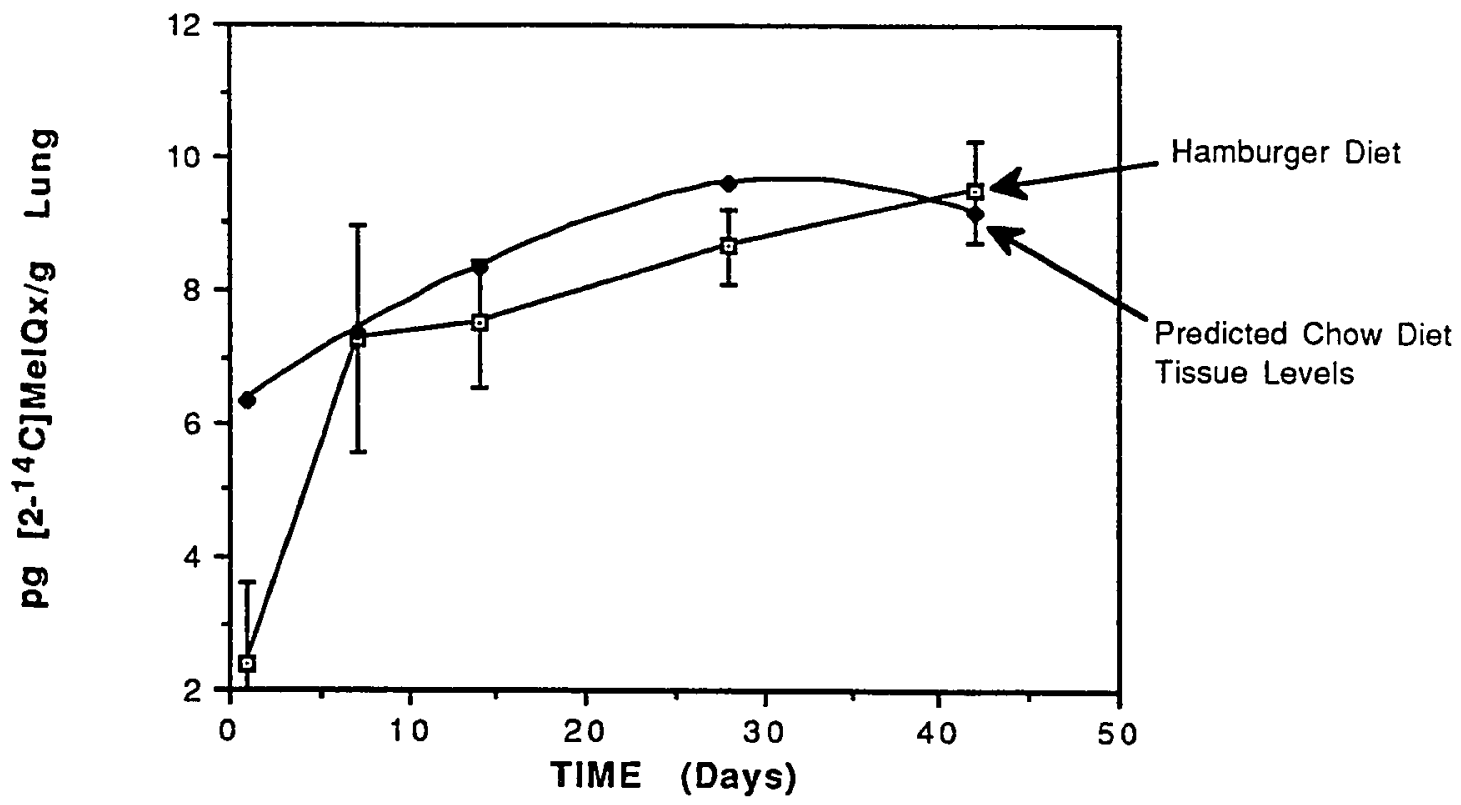

FIGURE 22. Comparison of actual response from dose in hamburger and predicted response from dose in chow in rat lung tissue. The difference in lung $[2.14 \mathrm{C}] \mathrm{MelQx}$ levels as a result of exposure to the low laboratory chow dose $[47 \mathrm{ng} / \mathrm{kg} / \mathrm{day}]$ and the higher laboratory chow dose [117 ng/kg/day] was $5.6 \mathrm{pg} / \mathrm{g}$ lung. In Figure 22, $5.6 \mathrm{pg}$ was added to each low chow time point response to arrive at the predicted chow diet lung tissue concentration. 


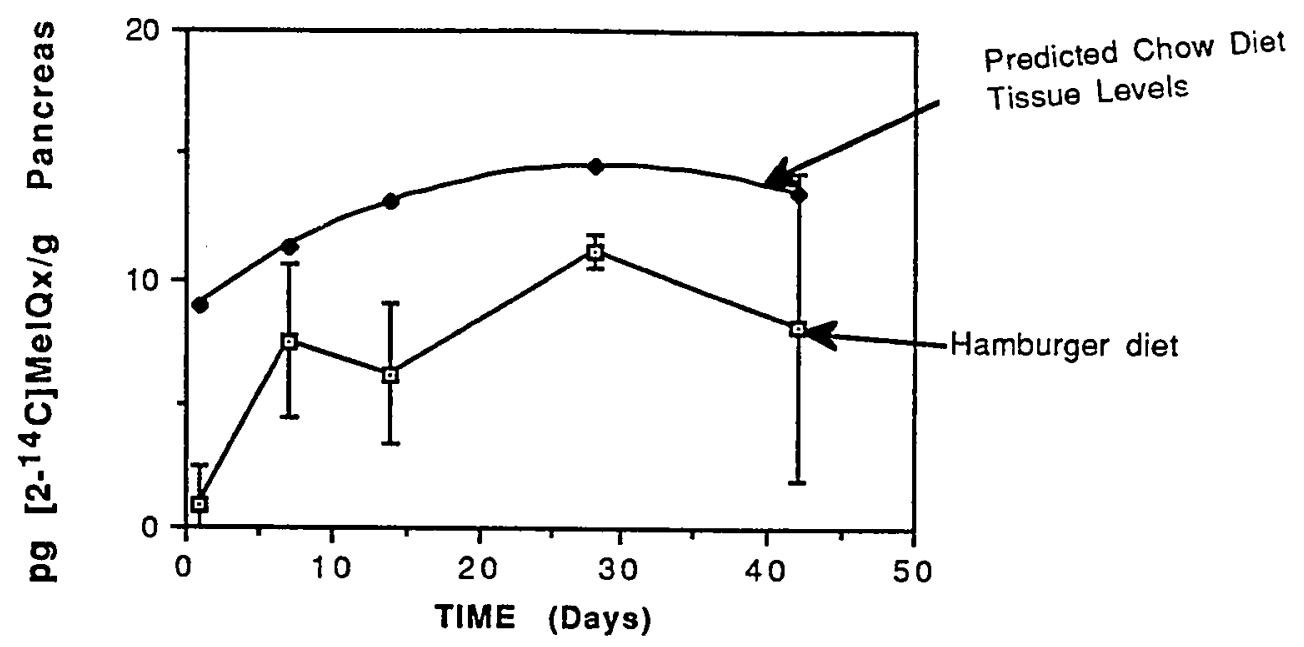

FIGURE 23. Comparison of actual response from dose in hamburger and predicted response from dose in chow in rat pancreas tissue. The difference in pancreas $\left[2-{ }^{14} \mathrm{C}\right] \mathrm{MelQx}$ levels as a result of exposure to the low laboratory chow dose [47 ng/kg/day] and the higher laboratory chow dose [117 ng/kg/day] was $8.62 \mathrm{pg} / \mathrm{g}$ pancreas. In Figure $23,8.62 \mathrm{pg}$ was added to each low chow time point response to arrive at the predicted chow diet pancreas tissue concentration. 


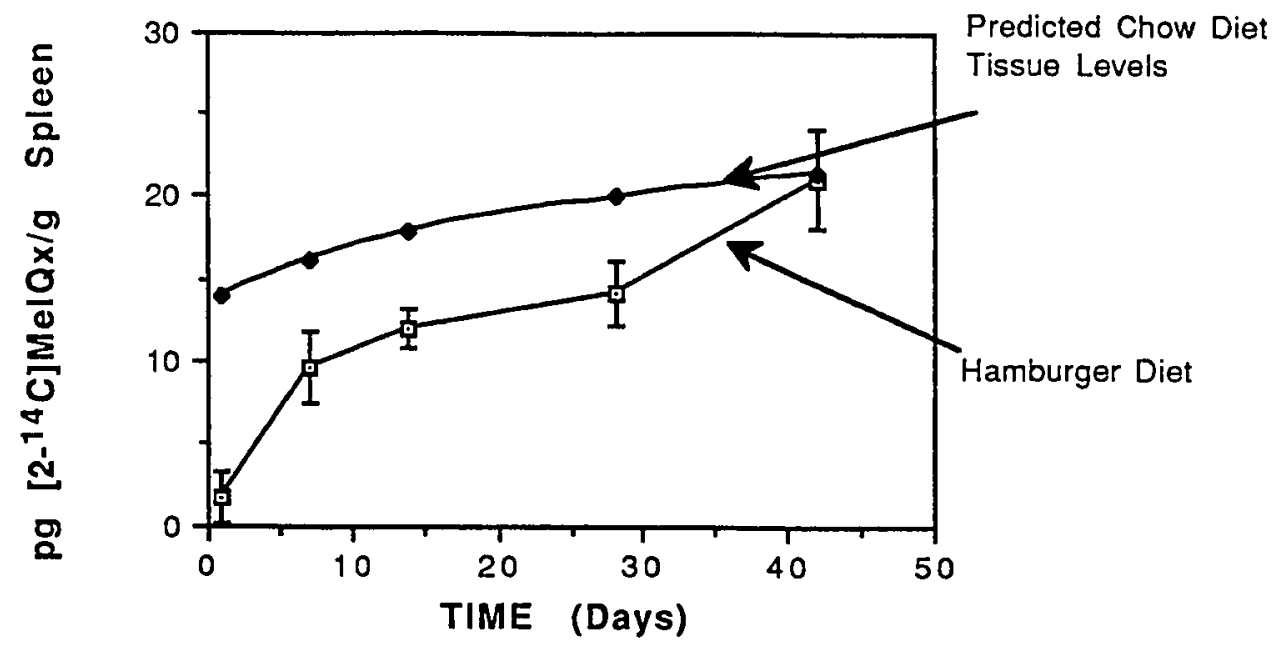

FIGURE 24. Comparison of actual response from dose in hamburger and predicted response from dose in chow in rat spleen tissue. The difference in spleen $\left[2-{ }^{14} \mathrm{C}\right] \mathrm{MelQx}$ levels as a result of exposure to the low laboratory chow dose [47 ng/kg/day] and the higher laboratory chow dose [117 ng/kg/day] was $13.13 \mathrm{pg} / \mathrm{g}$ spleen. In Figure 24, $13.13 \mathrm{pg}$ was added to each low chow time point response to arrive at the predicted chow diet spleen tissue concentration. The spleen was the only tissue that showed a significant effect due to diet $(p=0.0040)$. The dose was much more significant $(p=0.0001)$, and since no other tissue showed an effect due to diet, the effect of diet in the spleen was not used for comparative purposes. 


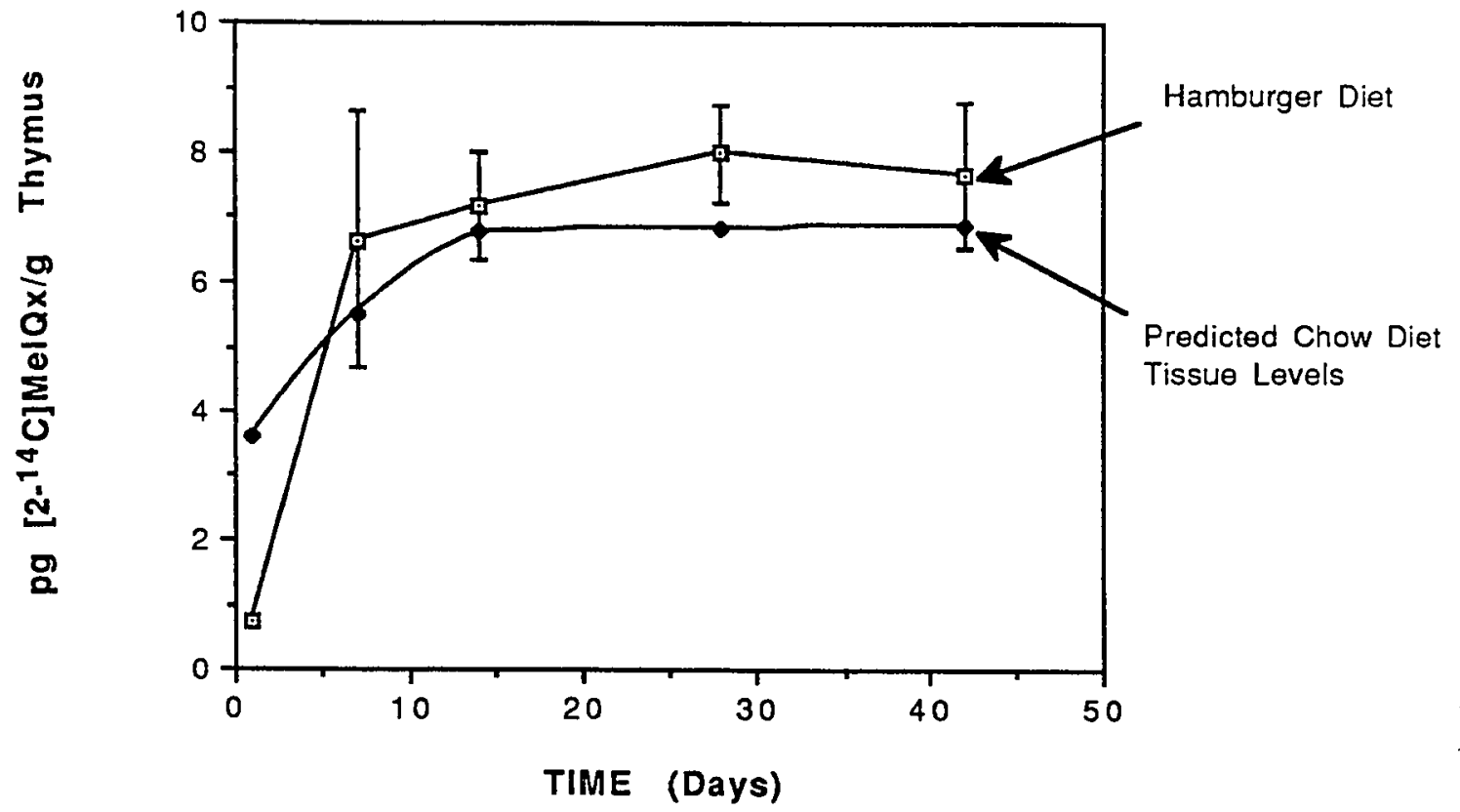

FIGURE 25. Comparison of actual response from dose in hamburger and predicted response from dose in chow in rat thymus tissue. The difference in thymus $\left[2 .{ }^{14} \mathrm{C}\right] \mathrm{MelQx}$ levels as a result of exposure to the low laboratory chow dose $[47 \mathrm{ng} / \mathrm{kg} / \mathrm{day}]$ and the higher laboratory chow dose [117 ng/kg/day] was $3.637 \mathrm{pg} / \mathrm{g}$ thymus. In Figure $25,3.637 \mathrm{pg}$ was added to each low chow time point response to arrive at the predicted chow diet thymus tissue concentration. 


\section{Examination of DNA Dose Response}

The DNA results showed definite trends of increasing with time, but several problems were encountered with the DNA data. The first was the lower response encountered by the higher dose (Figures 15 and 16). There are several possible explanations for this occurrence. The results may be real, and it is possible that a large variation in response may occur within the dose range given to the rats. The sample size may not have been large enough to detect this. This possibility also explains why at the seven day point the low dose in the laboratory chow the DNA adduct levels 8.5 adducts $/ 1012$ nucleotides were comparable to the DNA adduct levels, 5.6 adducts/1012 nucleotides, while the laboratory chow at the high dose produced only 0.3 adducts $/ 1012$ nucleotides.

The diet could be a factor, but the available [2-14C]MelQx in liver tissue shows the tissue level of MelQx to be comparable. At higher doses the adduct levels have been shown to be dose dependent (8) and since the amount of MelQx that is available to bind to DNA is dependent on the concentration, it follows that since the diets did not effect liver tissue levels of MelQx, they probably did not effect the DNA adduct levels. This would not hold to be true if the diets induced different or different levels of biotransformation enzymes that could result in metabolism of the parent MelQx compound to a more or less reactive form. 
The final difficulty encountered was the contamination of the control animals' liver DNA. The control DNA had an elevated level of carbon-14. The animals received no carbon-14 in their diets, and no other source of contamination was apparent. The samples were thought to be contaminated during sample processing. This brings up several points. Both the control sets of DNA were above contemporary levels of carbon-14. Neither of these control groups received any carbon-14 tracer in their diets, so it is postulated that the DNA was contaminated during isolation or preparation for AMS. The controls were above most of the test groups level of [2${ }^{14} \mathrm{C}$ ]MelQx. Since these animals received no known carbon-14 tracer they can be considered a worse case contamination event, and there are still measurable [2-14 C]MelQx levels in the test group DNA at 28 and 42 days. If all the samples were contaminated, or even some random contamination occurred, the trend of an increasing level of [2-14 C]MelQx adducts in DNA until a steady-state is achieved still exists and can not be discounted. Contamination increases the uncertainties, or in the worse case the units of measurement will change.

Another explanation for the elevated control values is possible. If the carbon-14 present in the samples is at the lower window of the sensitivity range, the lower concentrations of [2$\left.{ }^{14} \mathrm{C}\right] \mathrm{MelQx}$ adducts might be in an inherent background noise range. 
All these possibilities need to be explored further and the questions answered before the results can be considered completely reliable. Studies are currently in process, but will not be within the realm of this thesis project.

\section{Absence of Diet Effect}

When this thesis experiment was designed, the diet was expected to have an effect on the level of $\left[2-{ }^{-14} \mathrm{C}\right] \mathrm{MelQx}$ levels in the tissues and adduct levels in DNA. The fact that the tissue concentrations of $[2-14 \mathrm{C}] \mathrm{MelQx}$ were approximately equal in the tissues, shows that MelQx was equally absorbed from the two different diet matrices.

If the actual diets are examined closely, they provide some clues as to why. Each rat in the test chow groups received $16.9 \mathrm{~g} \mathrm{a}$ day of spiked laboratory chow. The cooked hamburger test group received $12.5 \mathrm{~g}$ of cooked hamburger and $6.58 \mathrm{~g}$ of laboratory chow. The cooked hamburger test group received about $40 \%$ as much lab chow as the test chow group. According to the analysis provided by the manufacturer the chow diet consists of $6.36 \%$ fiber. The test chow group received approximately $1.1 \mathrm{~g}$ of fiber each day and the hamburger fed group received $0.4 \mathrm{~g}$ of fiber each day. The test chow contained $21.2 \%$ protein and $4.41 \%$ fat compared to $25.6 \%$ protein and $17 \%$ fat in the cooked hamburger $(44,45)$. The two diets varied most in fiber and fat percentages, but the differences were probably not great enough to cause a difference in absorption from the gastrointestinal tract. This appears to be the most likely explanation, since the animals fed the cooked hamburger received the same dose each day for seven days compared to rats fed the adjusted chow. The tissue levels in these two test groups were equal. 


\section{Dose Effect}

If the two diets used in this study can be said to have no significant effect on tissue levels, then it is possible to examine the dose response relationship that exists between the two doses. In Figures 26 and 27 the dose response relationship in the kidney and liver are plotted at each measured time point. These plots show that the response increases with an increase in dose. Since only two points were measured the linearity can not be determined. This dose response relationship exists in all the rat tissues measured, but it is most apparent in the kidney and liver where the greatest response was seen.

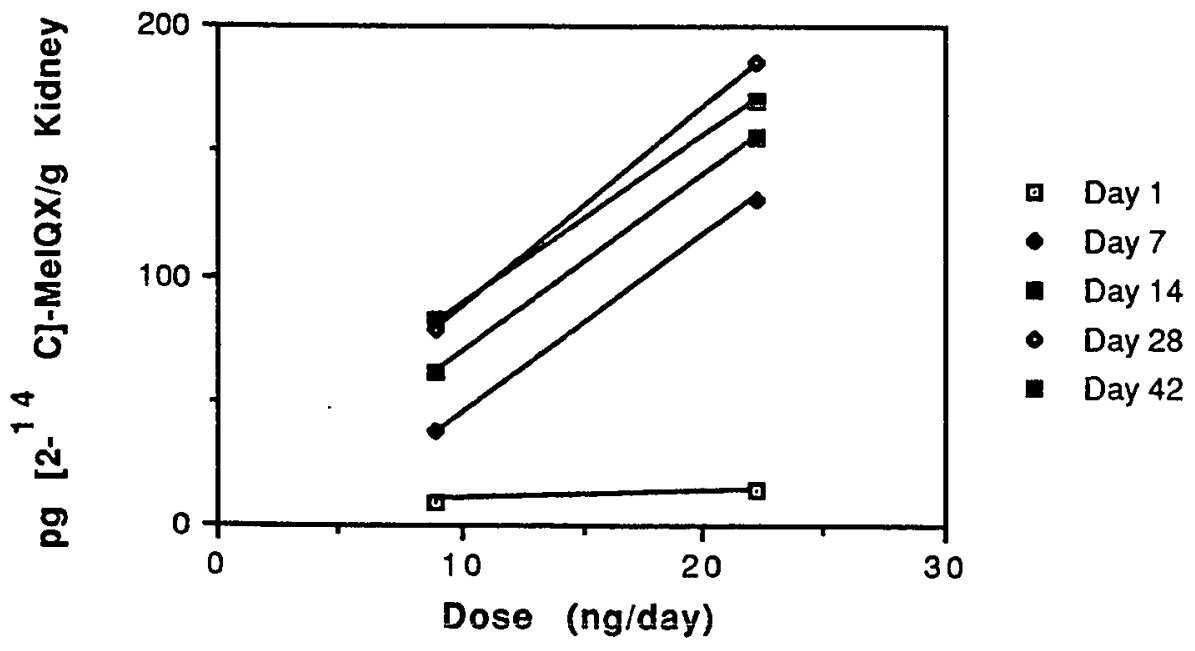

FIGURE 26. Dose response in rat kidney tissue. 


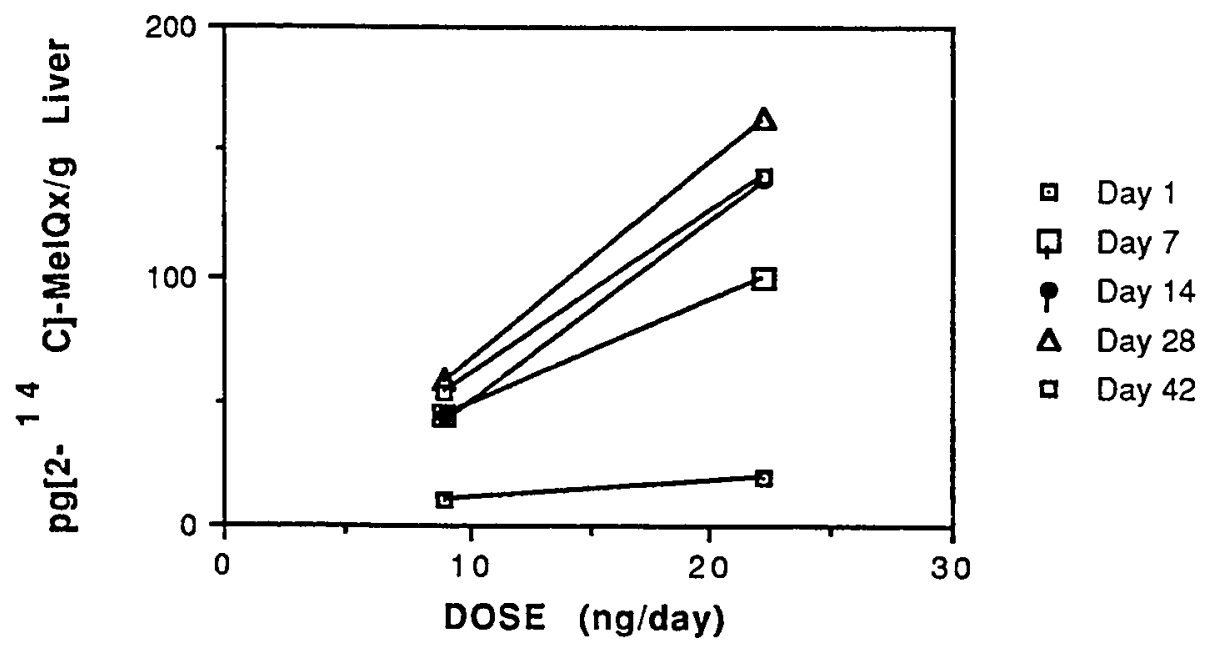

FIGURE 27. Dose response in rat liver tissue.

\section{Tissue Distribution and $[2-14 \mathrm{C}] \mathrm{MelQx}$ Steady State Levels}

Of all the tissues examined in the rats the liver and kidney had the highest levels of $[2-14 \mathrm{C}] \mathrm{MelQx}$. All the other tissues showed roughly the same response and levels of $[2-14 \mathrm{C}] \mathrm{MelQx}$. MelQx is absorbed through the gastrointestinal tract and the compound is passed from the blood into the liver, where the majority of metabolism occurs via cytochrome P450, sulfamate, and glucuronide formation $(28,32)$. MelQx has also been shown to be preferentially excreted in the urine in non-induced male Sprague-Dawley rats (32), and so it is not surprising to find a high level of $[2-14 \mathrm{C}] \mathrm{MelQx}$ in the kidneys. 
All the tissues and the liver DNA appeared to reach a steady state level between 14 and 28 days of exposure. This is similar to the findings by Yamashita et al. who found that DNA adducts in the livers of male F344 rats reached a steady state within 4 weeks of exposure to $400 \mathrm{ppm}$ of MelQx in a laboratory chow diet.

In carcinogenicity studies with MelQx male F344 rats fed $0.04 \% \mathrm{MelQx}$ in a laboratory chow diet for an extended time period developed tumors in liver (100\%), zymbal gland $(75 \%)$, and the skin $(35 \%)$. In this thesis zymbal gland and skin tissue were not measured. The high level of $[2-14 \mathrm{C}] \mathrm{MelQ}$ found in livers of the rats exposed to human equivalent doses does point to the liver being an organ that receives more MelQx and thus may be more susceptible to tumor formation. The carcinogenic dose was approximately 105 times higher than the dose the rats in this study received. No tumors were found in the rats exposed to human levels of MelQx for 6 weeks. The carcinogenicity study did not find any tumors in the kidney, and the kidney was found to have levels approximately equal to those found in the liver of male Sprague-Dawley rats.

This might be explained by the different functions of the two organs. The liver is the major xenobiotic metabolizing organ, and probably absorbs the parent MelQx compound from the blood and transforms it to an excretable form or a potentially DNA reactive form. The kidney, functioning as a blood filter and excretion organ probably encounters the MelQx metabolite that has been metabolized into a detoxified water soluble and excretable form and is not DNA reactive. 


\section{DNA Adducts}

The liver DNA adducts formed in male Sprague-Dawley rats fed 0.6 and $2.0 \mathrm{ng} / \mathrm{g}$ [2-14 C]MelQx (0.6 and $2.0 \mathrm{ppb})$ for 42 days are compared to the liver DNA adducts measured by Yamashita et al. (8) in Figure 26. In the study by Yamashita et al. male F344 rats were fed $0.4,4,40$, and $400 \mathrm{ppm}$ of MelQx and the liver DNA adducts were measured at 7 days. The adducts in this thesis were measured by AMS, and the liver DNA adducts were measured after 42 days exposure. Despite the differences it is interesting to compare the results of the two studies and the dose response relationship that can be developed using actual data. 


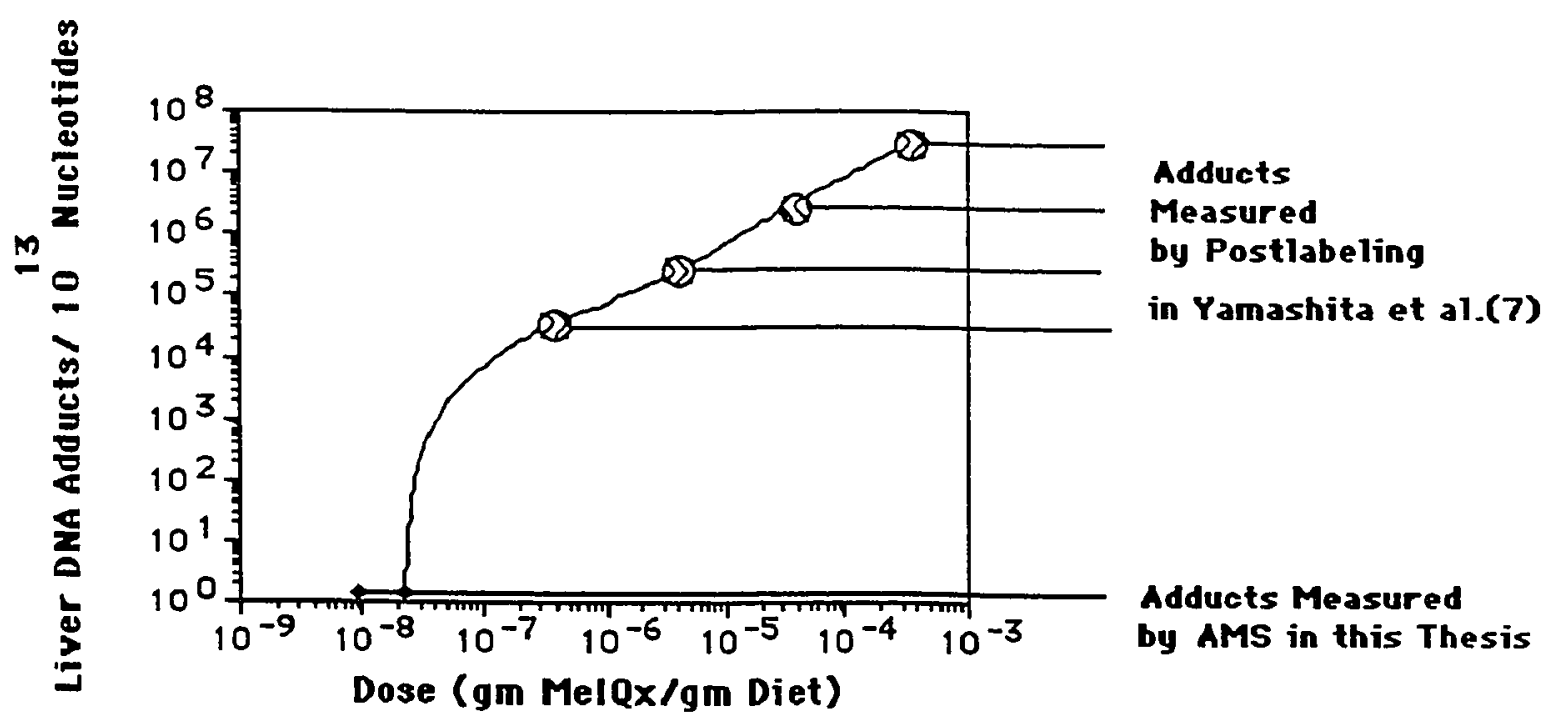

FIGURE 28. Liver DNA adducts/ $10^{13}$ nucleotides v. dose of MelQx. The 4 high dose data points are from the study by Yamashita et al (7), the 2 lower dose data points are the 42 day time points from this thesis.

If the data on the DNA adducts can be considered usable, then actual low dose measurements can be compared to the adducts formed at carcinogenic levels and the shape of the dose-response curve can estimated. Using the adduct measurements made in this study the shape of the curve appears to be sublinear. 


\section{Risk Assessment}

Using the DNA adducts and tissue levels of MelQx measured in this thesis, the formation of DNA adducts appears to decline drastically at low human equivalent exposure levels when compared to the higher carcinogenic dose fed to rats. There is a $10^{7}$ decline in the levels of adducts formed at rat carcinogenic dose of $400 \mathrm{ppm}$ MelQx in the diet to the DNA adducts formed in rats at human equivalent doses. The primary mechanism of MelQx carcinogenicity is thought to be DNA damage $(8,46)$. If the occurrence of DNA damage is very low in rats when they are exposed to relevant levels of MelQx, then the risk of tumor formation can then be extrapolated to also be low in rats.

The use of animal models is currently an accepted method of testing the carcinogenicity of chemicals (47). DNA adducts are also considered a valid method of assessing exposure to a genotoxic chemical (48). There is still not a completely accurate method of extrapolating the toxicological results measured in animal models to humans, however it is the best current method. With all this in mind the initial findings of this thesis, which need verification and further study, indicate that MelQx is not an exceptionally dangerous chemical when received in low doses. This finding corresponds to what the Swiss physician Paracelsus wrote in the 1500's "What is it not that is not a poison? All things are poison and nothing is without poison. It is the dose only that makes a thing not a poison" (49). 


\section{Summary}

The initial question asked in this thesis was, what effect does diet exert on tissue levels and DNA adducts in rats exposed to human equivalent doses of MelQx. The results show that after seven days of exposure the effect of the two diets used in this study was not significant, and that dose was the significant factor in tissue levels and DNA adducts caused by exposure to [2-14C]MelQx. The seven day results were used in conjunction with analysis of variance to extrapolate the results across the entire 42 day study. In addition to answering questions about the role of diet, tissue levels and DNA adducts were measured in rats exposed to a chemical carcinogen, MelQx, at levels equivalent to human exposure for an extended period for the first time. The initial findings presented by this thesis indicate that MelQx is less genotoxic at low doses. 


\section{REFERENCES}

1) Gove PB, (ed) (1976) Websters Third New International Dictionary of the English Language Unabriged, G\&C Merriam Publisher, Springfield Massachetts, USA.

2) Doll R, Peto R, The Causes of Cancer: Quantitive estimates of avoidable risks of cancer in the United States today. (1981) Journal National Cancer Institute, (66)6:1191-1308.

3) Larsen JC, Dragsted LO, Frandsen H, Kristiansen E, Rasmussen ES, Nielsen PA, Knudsen I. (1990) Carcinogenicity of mutagens from cooked meats. In: Mutagens and Carcinogens in the Diet, Wiley-Liss , 89-108.

4) Felton JS, Knize MG, Shen NH, Andresen BD, Bjeldane LF, Hatch FT. (1986) Identification of the mutagens in cooked beef. Environmental Health Perspectives, 67:17-24.

5) Felton JS, Knize MG, (1990) Heterocyclic-amine mutagens/carcinogens in foods. In: Cooper CS, Grover PL (eds) Handbook of Experimental Pharmocology, Vol 94/I SpringerVerlag Berlin Heidelberg, 471-502.

6) Kato $T$, Ohagaki $H$, Hasegawa $H$, Sato $S$, Takayama $S$, Sugimura $T$, (1988) Carcinogenicity in rats of a mutagenic compound 2amino-3,8-dimethylimidazo[4,5-f ]quinoxaline. Carcinogenesis, 9:71-73.

7) Ohagaki H, Hasegawa $H$, Suenaga $M$, Sato $S$, Takayama $S$, Sugimura T, (1987) Carcinogenicity in mice of a mutagenic compound 2-amino-3,8-dimethylimidazo[4,5-f] quinoxaline. Carcinogenesis, 8:665-668. 
8) Yamashita $K$, Adachi $M$, Kato $S$, Nakagama $H$, Orchiai $M$, Wakabayashi K, Sato S, Nagao, Sugimura T, (1990) DNA adducts formed by 2-amino-3,8-dimethylimidazo[4,5,-f] quinoxaline in rat liver: dose response on chronic administration. Japanese Journal of Cancer Research, 81:470476.

9) Van Eys J, (1984) Nutrition and Neoplasia In Olson et al. (eds) Present Knowledge in Nutrition. Nutrition Foundation Washington, D.C., 840-851.

10) Roe DA, (1984) Nutrient and drug interactions In Olson et al. (eds) Present Knowledge in Nutrition. Nutrition foundation Washington, D.C., 797-818.

11) Sugimura $T$, Nagao $M$, Kawachi $T$, Honda $M$, Yahagi $T$, Seino $Y S$, Matsukura N, Matsushima T, Shirai A, Sawamura M, Matsumoto $H$, (1977) Mutagen-carcinogens in food, with special reference to highly mutagenic pyrolytic products in broiled foods. In : (eds) Hiatt $\mathrm{HH}$, Watson JD, Winsten JA, Origins of human cancer. Coldspring Harbor Laboratory, 1561-1577.

12) Widmark EMP, (1939) Presence of Cancer-producing substances in roasted food. Nature, 143:984.

13) Nagao $M$, Honda $M$, Seino $Y$, Yahagi $T$, Sugimura $T$ (1977) Mutagenicities of smoke condensate and the charred surface of fish and meat. Cancer Letters, 2:22!-226.

14) Vithayathil AJ, Commoner B, Nair S, Madyastha P, (1978) Isolation of mutagens from bacterial nutrients containing beef extract. Journal of Toxicology and Enviornmental Health, 4:189-202. 
15) Commoner B, Vithayathil AJ, Dolara $P$, Nair $S$, Madyastha $P$, Cuca GC, (1978) Formation of mutagens in beef and beef extract during cooking. Science, 20:913-916.

16) Sugimura $T,(1986)$ Studies on environmental chemical carcinogenesis in Japan. Science, 233:312-318.

17) Hatch FT, (1986) A current genotoxicity database for heterocyclic thermic food mutagens. I. Genetically relevant endpoints. Environmental Health Perspectives, 67:93-103.

18) Sugimura $T$, (1985) Carcinogenicity of mutagenic heterocyclic amines formed during the cooking process. Mutation Research, $150: 33-41$.

19) Ohgaki $H$, Hasegawa $H$, Kato $T$, Suenaga $M$, Ubukata $M$, Sato $S$, Takayama S, Sugimura T, (1986) Carcinogenicity in mice and rats of heterocyclic amines in cooked foods. Enviornmental Health Perspectives, 67:129-134.

20) Adamson RH, Thorgeirsson UP, Snyderwine EG, Thorgeirsson, SS, Reeves J, Dalgard DW, Takayama S, Sugimura T. (1990) Carcinogenicity of 2-amino-3methylimidazo[4,5-f]quinoline in non-human primates: induction of tumors in three macaques. Japanese Journal of Cancer Research, 81:10-14.

21) Ames BN, Durston WE, Yamasaki E, Lee FD (1973) Carcinogens are mutagens: A simple test system combining liver homogenates for activation and bacteria for detection. Proc. Nat. Acad. Sci. USA (70)8:2281-2285. 
22) Mizusaki S, Takashima $T$, Tomaru K, (1977) Factors affecting mutagenic activity of cigarette smoke condensate in

Salmonella typhimurium TA 1538. Mutation Research, 48:2936.

23) Williams GM, Weisburger JH, (1986) Chemical carcinogens. In Klaassen CD, Amdur MO, Doull (eds) Casarett and Doull's Toxicology, Third edition, Macmillan Publishing Company, New York, New York, 99-173.

24) Esumi H, Ohgaki H, Kohzen E, Takayama S, Sugimura T, (1989) Induction of lymphoma in $\mathrm{CDF}_{1}$ mice by the food mutagen, 2Amino-1-methyl-6-phenylimidazo[4,5,-b ]pyridine. Japanese Journal of Cancer Research, 80:1176-1178.

25) Ito N, Hasegawa R, Sano M, Tamano S, Esumi E, Takayama S, Sugimura T (1991) A new colon and mammary carcinogen in cooked food, 2-amino-1-methyl-6-phenylimidazo[4,5,-b ] pyridine (PhIP). Carcinogenesis (12)8:1503-1506.

26) Miller JA, Miller EC, (1981) Mechanisms of chemical carcinogenesis. Cancer, 47:1055-64.

27) Hemminki K, (1983) Nucleic acid adducts of chemical carcinogens and mutagens. Archives of Toxicology, 52:249285.

28) Turteltaub KW, Watkins BE, Vanderlaan M, Felton JS, (1990) Role of metabolism on the DNA binding of MelQx in mice and bacteria. Carcinogenesis, (11)1:43-49. 
29) Turteltaub KW, Felton JS, Gledhill BL, Vogel JS, Southton JR, Caffe MW, Finkel RC, Nelson DE, Proctor ID, Davis JC, (1990) Accelerator mass spectrometry in biomedical dosimetry: relationship between low-level exposure and covalent binding of heterocyclic amines carcinogens to DNA. Proceedings of the National Academy of Science. USA, 87:5288-5292 (Medical Sciences).

30) Buonarti MH, Roper M, Morris CJ, Happe JA, Knize MG, Felton James, (1991) Metabolism of 2-amino-1-methyl-6phenlimidazo[4,5,-b]pyridine (PhiP) in mice. Submitted to Carcinogenesis 9/19/91.

31) Buonarti MH, Turteltaub KW, Shen NH, Felton JS, (1990) Role of Sulfation and acetylation in the activation of 2 hydroxyamino-1-methyl-6-phenylimidazo[4,5,-b]pyridine to intermediates which bind DNA. Submitted to Mutation Research Letters 6/8/90

32) Turesky RJ, Markovic J, Bracco-Hammer I, Fay LB. (1991) The effect of dose and cytochrome P450 induction on the metabolism and disposition of the food-borne carcinogen 2amino-3,8-dimethylimidazo[4,5-f]quinoxaline (MelQx) in the rat. (12)10:1847-1855.

33) Vogel JS, Turteltaub KW, (1992) Biomolecular tracing through accelertor mass spectrometry. (In Press: Trends in Analytical Chemistry April 1992)

34) Vogel JS, (1992) Rapid production of graphite without contamination for biomedical AMS. In Press: Radiocarbon vol 34.

35) Vogel JS, Turteltaub KW, Felton JS, Gledhill BL, Nelson DE, Southton JR, Proctor ID, Davis JC (1990) Application of AMS to the biomedical sciences. Nuclear Instrumental Methods in Physics Research, B52:524-540. 
36) Turteltaub KW, Felton JS, Vogel JS, Balhorn RL, Gledhill BL (1991) AMS in biomedical dosimetry. Energy and Technology Review May-June 1991, 48-55.

37) Turteltaub KW, Vogel JS, Frantz C, Buonarti MH, Felton JS, (1991) Low-level biological dosimetry of heterocyclic amine carcinogens isolated from cooked food. Submitted to Enviornmental Health Perspectives 9/23/91.

38) Knize MG , and Gross GA, Personal communication.

39) Gross GA, Gruter A, (1991) Quantitation of mutagenic/carcinogenic heterocyclic aromatic amines in food products. Journal of Chromatography Symposia,592:271-278.

40) Mosber AT, Hayes AW, (1989) Subchronic toxicity testing in Hayes AW (ed) Principles and methods of toxicology 2nd edition Raven Press New York, Chapter 7.

41) Hedges RE, Gowlett JAJ, (1986) Radiocarbon dating by accelerator mass spectrometry. Scientific American (254) $1: 100-107$

42) Vuolo LL, Schuessler GJ, (1985) Review:Putative mutagens and carcinogens in foods VI. protein pyrolysate products.

Environmental Mutagenesis 7:577-598.

43) Gibaldi G, Perrier D. (1982) Pharmacokinetics 2nd edition Marcel Dekker Inc. New York, New York Chapter 4.

44) Written communication from Simonsen Laboratories, Gilroy $\mathrm{Ca}$

45) Pennington JAT, Chruch HN, (1985) Bowes and Chruch's Food values of portions commonly used. 14th edition Harper and Row New York p100. 
46) Ames BN, McCann J, Yamasaki E, (1975) Methods for detecting carcinogens and mutagens with the salmonella/mammalianmicrosome mutagenicity test. Mutation Research, 31:347-363.

47) Robens JF,Piegorsch WW, Schueler RL (1989) In Hayes AW (ed) Principles and methods of toxicology 2nd edition Raven Press New York Chapter 9.

48) Wogan GN, (1989) Markers of exposure to carcinogens. Environmental Health Perspectives, 81:9-17

49) Ottoboni MA (1986) The dose makes the poison. A plainlanguage guide to toxicology. Vincente Books, Berkeley, California. 


\section{APPENDIX ONE}

\section{DNA ISOLATION}




\section{PROTOCOL FOR GENOMIC DNA ISOLATION}

Buffer Preparation

Lysis Buffer
$4 \mathrm{M}$ Urea
$1 \%$ Triton X-100
$10 \mathrm{mM}$ EDTA
$100 \mathrm{mM} \mathrm{NaCl}$
$10 \mathrm{mM}$ Tris-HC pH 8.0
$10 \mathrm{mM} \mathrm{DTT}$
Buffer Lambda
$1.25 \mathrm{M} \mathrm{NaCL}$
$50 \mathrm{mM} \mathrm{MOPS}$
$15 \%$ EtOH
pH 8.0 !!

$\begin{array}{ll}\frac{\text { Buffer } B}{750 \mathrm{mM} \mathrm{NaCl}} & \frac{\text { Buffer } C}{1 \mathrm{M} \mathrm{NaCl}} \\ 50 \mathrm{mM} \mathrm{MOPS} & 50 \mathrm{mM} \mathrm{MOPS} \\ 15 \% \text { EtOH } & 15 \% \text { EtOH } \\ \text { pH } 7.0 & \text { pH } 7.0\end{array}$

Additional Reagents

$5 \mathrm{M} \mathrm{NaCl}$

1 M MOPS

$70 \% \mathrm{EtOH}$

$100 \%$ IPA (Keep in Freezer)

DTT $==$ Dithiolthreitol

MOPS $=$ (3-[N-Morpholimo]propane-sulfonic acid)

IPA = Isopropyl alcohol

Notes: Use 2- 10x solutions to prepare buffers.

Store buffers at $4^{\circ} \mathrm{C}$ Allow buffers B,C \& Lambda to come to room temperature before use.

USE LYSIS BUFFER SAME DAY IT IS MADE!

$\mathrm{pH} 10 \times$ EDTA solution to $\approx 8.0$

$\mathrm{pH} 1 \mathrm{M}$ MOPS solution to 7.0

Do not $\mathrm{pH}$ adjust $\mathrm{NaCl}$ or Urea $10 \mathrm{X}$ solns.

Use new ,disposable test tubes etc. to prevent ${ }^{14} \mathrm{C}$ cross contamination.

Use Quiagen Columns of appropriate size, from Quiagen company. 
Procedure

1) - Check the $\mathrm{pH}$ of all buffers

- Store tissue at $-20^{\circ} \mathrm{C}$.

-Large Tissue Preparation for DNA isolation

- Obtain liquid $\mathrm{N}_{2}$ and place into a Dewar.

-Wrap tissue sample in saran wrap.

-Immerse tissue in Liquid Nitrogen for $\approx 15$ seconds.

-Immediately withdraw and place on a new piece of aluminum

foil, fold the foil over the tissue and pound tissue with a light

mallet until tissue completely powdered.

-Remove all plastic wrap and using lysis buffer wash the tissue into a disposable test tube for tissue lysis.

- Incubate tissue at $37^{\circ} \mathrm{C}$ to $40^{\circ} \mathrm{C}$ for 2 hours in shaking water bath.

- Just prior to incubation add 800 ug of Proteinase $\mathrm{K}$ per $\mathrm{ml}$ of lysis buffer.

2) Centrifuge at maximum speed $\left(4^{\circ} \mathrm{C}\right)$ for $5-10$ minutes and harvest supernatant. Do remove any of the pellet.

Note: The larger the volume and slower speed may necessitate increased centrifuging time.

3) Add 50 ul of RNAase A and 50 ul of RNAase T1 (stock concentration [100 ug/ml] ) for each $\mathrm{ml}$ of supernatant. Mix thoroughly and allow to incubate on ice for 10-15 min.

4) Shear DNA by passing through a 22 to 26.5 gauge needle 10 times. Keep on ice during the shearing.

5) Adjust supernatant to binding conditions. Add 50 ul of $1 \mathrm{M}$ MOPS (pH 7.0) per $\mathrm{ml}$ of supernatant, and 180 ul of $5 \mathrm{M} \mathrm{NaCl}$ per $\mathrm{ml}$ of supernatant. Keep on ice. (Check pH of this solution if a problem arises)

6) Equilibrate Quiagen column with 1 column volume of Buffer B containing $0.15 \%$ Triton $\mathrm{X}-100$.

7) Load supernatant onto column. ( Load only one column volume) ( Save loading elutant) 
8) Wash column, with 2-3 column volumes of buffer $C$. (Save Wash elutant)

9) Elute DNA with 1.5 column volumes of Buffer Lambda (Measure and record O.D. 260/280)

10) DNA may be precipitated by addition of 0.8 to 1.0 volumes of $100 \%$ IPA for 20 minutes on ice. (Alternatively this can be left overnight in the freezer) Centrifuge cold at max speed (20 $\mathrm{min}$ at $14 \mathrm{~g}$ for eppendorf tubes, $2-3 \mathrm{hrs}$ at $3000 \mathrm{rpm}$ for $50 \mathrm{ml}$ tubes) Remove supernatant and wash pellet with ice cold $70 \% \mathrm{EtOH}$. Remove EtOH and leave pellet in open tube to air dryMeasure the 0.D. 260/280 (Should be $\approx 1.8$ ) and calculate the concentration using 50ug DNA/ 1.0 Absorbance units $=x$ ug DNA/Absorbance. 


\section{APPENDIX TWO}

CALCULATION OF [2-14C]MEIQx LEVELS 
For purposes of example liver tissue that is 12 modern will used be to do the calculations.

First contemporary ${ }^{14}$ Carbon levels are subtracted out.

12 Modern - 1.18 Modern (Contemporary level) $=10.82$ Modern

The following relationship is used:

$5.9 \times 10^{10} 14 \mathrm{C} / \mathrm{g}$ carbon $\times 10.82$ Modern $=$ $6.38 \times 10^{11}{ }^{14} \mathrm{C} / \mathrm{g}$ liver tissue

As determined by carbon analysis, rat liver is $13.4 \%$ carbon so there are $0.134 \mathrm{~g}$ carbon $/ \mathrm{g}$ rat liver tissue.

$6.38 \times 101114 \mathrm{C} / \mathrm{g}$ carbon $\mathrm{X} .134 \mathrm{~g} \mathrm{C} / \mathrm{g}$ liver tissue $=$ $8.29 \times 10^{10} 14 \mathrm{C} / \mathrm{g}$ liver tissue

The $[2-14 \mathrm{C}]-M e l Q x$ is $80 \%$ labeled $(41)$, so this is factored in to the calculation. It is also assumed here that each ${ }^{14} \mathrm{C}$ is associated with one MelQx molecule.

$8.29 \times 10^{10} 14 \mathrm{C} / \mathrm{g}$ liver tissue $X 1$ molecule $\mathrm{MelQ} \times / 0.8{ }^{14} \mathrm{C}=$ $1.14 \times 10^{11}$ molecules MelQx/g liver tissue.

Molecules are converted into mols; $6.02 \times 10^{23}$ molecules/moles:

$1.14 \times 10^{11} \mathrm{molecules} \mathrm{MelQx} / \mathrm{g}$ liver tissue $\times 1 \mathrm{~mol} / 6.02 \times 10^{23}$ molecules $/$ moles $=1.72 \times 10^{-13}$ moles $M e l Q x / g$ liver tissue.

Moles are then converted into grams using the F.W of $213 \mathrm{~g} / \mathrm{moles}$ for MelQx.

$1.72 \times 10^{-1} \mathrm{pmoles} / \mathrm{g}$ liver $X 213 \mathrm{pg} / \mathrm{pmoles}=36.66 \mathrm{pg} / \mathrm{g}$ liver tissue.

If the rats liver weighed $10 \mathrm{~g}$, then $10 \times 36.66 \mathrm{pg}=366.6 \mathrm{pg}$ of $\left[{ }^{14} \mathrm{C}\right]-\mathrm{MelQx}$ was present in the liver tissue sample at the time of measurement. 
To calculate the number of DNA adducts/g DNA.

Mols of $\left[{ }^{14} \mathrm{C}\right]-M e l Q x$ measured in the DNA sample is converted back to molecules, and every molecule of $\left[{ }^{14} \mathrm{C}\right]-\mathrm{MelQx}$ is assumed to be an adduct. One gram of DNA contains $1.95 \times 10^{21}$ nucleotides. Adducts measured are dividied by number of nucleotides present in the sample. 


\section{APPENDIX THREE}

HPLC PROTOCOL (38) 
STANDARD OPERATING PROCEDURE CREATED: $20.8 .1991 / G A G$
LAST UPDATE:

$\frac{\text { A }}{\text { 20.8.1991/GAG }}$

Quantification of MolOx, 4,8-DiMelQx, IQ, 4-MelQ, Glu-P-1, Glu-P2, PhIP, Trp-P-1, Trp-P-2, Amino-a-carboline, norharman, harman in

Beef extract, fried meat, fried flsh, process flavours

Abbreviations:

$\begin{array}{ll}\mathrm{NaOH} & \text { Sodium Hydroxide } \\ \mathrm{MeOH} & \text { Methanol } \\ \text { DCM } & \text { Dichloromethane } \\ \text { PRS } & \text { Propyl sulfonic acid silica }\end{array}$

\section{Preparation orocedure}

1 Rinse four $500 \mathrm{mg}$ Bond-Elut $\mathrm{C} 18$ cartridges with $2 \mathrm{ml} \mathrm{MeOH}$ and 10 $\mathrm{ml}$ water.

2 Rinse four $100 \mathrm{mg}$ Bond-Elut $\mathrm{C} 18$ cartridges with $2 \mathrm{mi} \mathrm{MeOH}$ and 5 mi water.

This preparation may carried out during the extraction

\section{Extraction procedure}

1a Soluble samples: Dissolve four 2-4 gram samples in 10-12 $\mathrm{ml} 1 \mathrm{~N}$ aqueous NaOH in SOVIREL tubes. Shake gently to avoid foaming!

1b Insoluble samples: Weigh out 10-12 grams sample (cut in small pieces) in a $100 \mathrm{ml}$ beaker. Add $18-20$ grams cold $\left(4^{\circ} \mathrm{C}\right) 1 \mathrm{~N}$ NaOH. Homogenize with Ultra-Turrax (incraase sposd carafully up to maximum, don't let the samole heat up!). The sample becomes a more or less compact gel or may remain liquid. Weigh the total sample to account for losses during homogenization. Put three weighed aliquots of about $1 / 4$ th in $100 \mathrm{ml}$ beakers, the remaining quarter represents sample *1. Put a spatula in each beaker.

2 Add the spiking cocktail, usually solution G194 or G194 dil. to samples $* 3$ and $\# 4$. Mix by gentle shaking (1a) or with the spatulas (1b). 
STANDARD OPERATING PROCEDUAE

CREATED: 20.8.1991/GAG

LAST UPDATE:

20.8.1991/GAG

3a Pour the sample solutions on Extrelut-20 columns placed on a Visiprep, aspire with max vacuum. Rinse tubes with $2 \mathrm{ml} 1 \mathrm{~N} \mathrm{NaOH}$.

3b To each beaker add the content of an Extrelut refill package in 3 to 4 portions. Mix woll with the spatulas aftor each addition ! The final mix must be a dry, freely flowing powder! Add these powders through a plastic funnel with large opening to empty Extrelut-20 reservoirs (don't forget to put the small filter unit in the bottom piece !). Put the cylindrical plastic inset with the upper filter unit in each Reservoir., don't compact the column with torce.

4 Fit a $3 \mathrm{ml}$ Bond-Elut PRS cartrldges with adaptor pieces at the top and fine luer needles (orange) at the bottom, then rinse each with $2 \mathrm{ml} \mathrm{DCM}$ (use plastic syringe to put air pressure). Let about $1 \mathrm{ml}$ DCM supernatant in the cartridges.

5 Fill DCM in the Extrelut cartridges and couple to PRS when DCM reaches the bottom of Extrelut. Extract with 40 or $50 \mathrm{ml}$ of DCM.

6 Remove PRS cartridges and dry them on the Visiprep under max vacuum for 4-5 min.

7 Transfer PRS cartridges to peristaltic pump.

8 Rinse 1: Re-equilibrate PRS with $6 \mathrm{ml} \mathrm{0.1N}$ aqueous $\mathrm{HCl}$ (1 $\mathrm{ml} / \mathrm{min})$.

9 Rinse 2: Pump $15 \mathrm{ml}$ of MOOH-0.1N HCI $4: 6$ (1 ml/min) through the PRS cartridges. Collect eluate in an empty Extrelut-20 cartridges fitted with a stopcock at the bottom.

10 Rinse 3: Pump $2 \mathrm{ml}$ of water through each cartridge $(1 \mathrm{ml} / \mathrm{min})$. collect witit rinas 2.

11 Remove Rinse 2 - solutions carefully and put the reservoirs on Visiprep. (Procedure continues with point 18)

Polar Extract

12 Connect 100mg Bond-Elut C18 cartridges (conditioned with $2 \mathrm{ml}$ $\mathrm{MeOH}, 5 \mathrm{ml}$ water)through adaptor pieces to the PRS cartridges.

Rinse 4: Pump $20 \mathrm{ml}$ of $0.5 \mathrm{~N}$ ammonium acetate buffer $\mathrm{pH} 8$ through the PRS-C18 tandem ( $1 \mathrm{~mL} / \mathrm{min}$ ).

13 Remove PRS cartridge, discard. 
STANDARD OPERATING PROCEDURE

CREATED: 20.8.1991/GAG

LAST UPOATE:

20.8.1991/GAG

14 Rinse 5: Pump $2 \mathrm{ml}$ water through $\mathrm{C} 18$ cartridges, remove from pump.

15 Dry C18 cartridges completely with positive nitrogen pressure.

16 Elute cartridges directly into $1.1 \mu \mathrm{HPLC}$ vial with $0.8 \mathrm{ml} \mathrm{HOOH}$ ammonia sol. 9:1. Use plastic syringe fitted with adaptor piece to put gentle pressure to $\mathrm{C} 18$ cartridges.

17 Concentrate extract solutions with nitrogen flow.

Apolar Extract

18 Neutralize with $100 \mu l$ concentrated ammonia solution ( pH 10) and dllute with $15 \mathrm{ml}$ water. Check pH with paper strip. Filter this solution through a conditioned Bond-Elut $\mathrm{C} 18$ cartridge (500 mg, $2 \mathrm{ml}$ MeOH, $10 \mathrm{ml}$ water) on the Visiprep. Use only minimal vacuum.

19 Rinse $\mathrm{C} 18$ cartridges with $2 \mathrm{ml}$ water on Visiprep.

20 Dry C18 cartridges complotoly with positive nitrogen pressure.

21 Elute cartridges directly into $1.1 \mu \mathrm{HPLC}$ vial with $1.2 \mathrm{ml} \mathrm{MeOH} \mathrm{-}$ ammonie sol. 9:1. Use plastic syringe fitted with adaptor piece to put gentle pressure to $\mathrm{C} 18$ cartridges.

22 Concentrate extract solutions with nitrogen flow.

Prepare Extracts for HPLC

23 Dissolve polar unsplked extracts in 20 - $40 \mu / 4,7,8$-TriMelQx intornal standard solution.

Dissolve polar splked extracts in $100 \mu 1$ 4,7,8-TriMelOx internal standard aolution.

Dissolve apolar unsplked extracts in 20 - $40 \mu / 7,8$ - DiMelOx Intornal standard solution.

Dissolve apolar splked extracts in $100 \mu l$ 7,8-DIMelQx internal standard solution.

Close vials with septum - scrow caps. 
STANDARD OPERATING PROCEDURE CAEATED:20.8.1991/GAG

LAST UPDATE:

A

20.8.1991/GAG

In case of insulficient selectivity due to coeluting impurities in HPLC, use the resolution improvement procedure with Fractogel TSK $\mathrm{CM} 650(x)$ 


$$
\text { 血的 }
$$

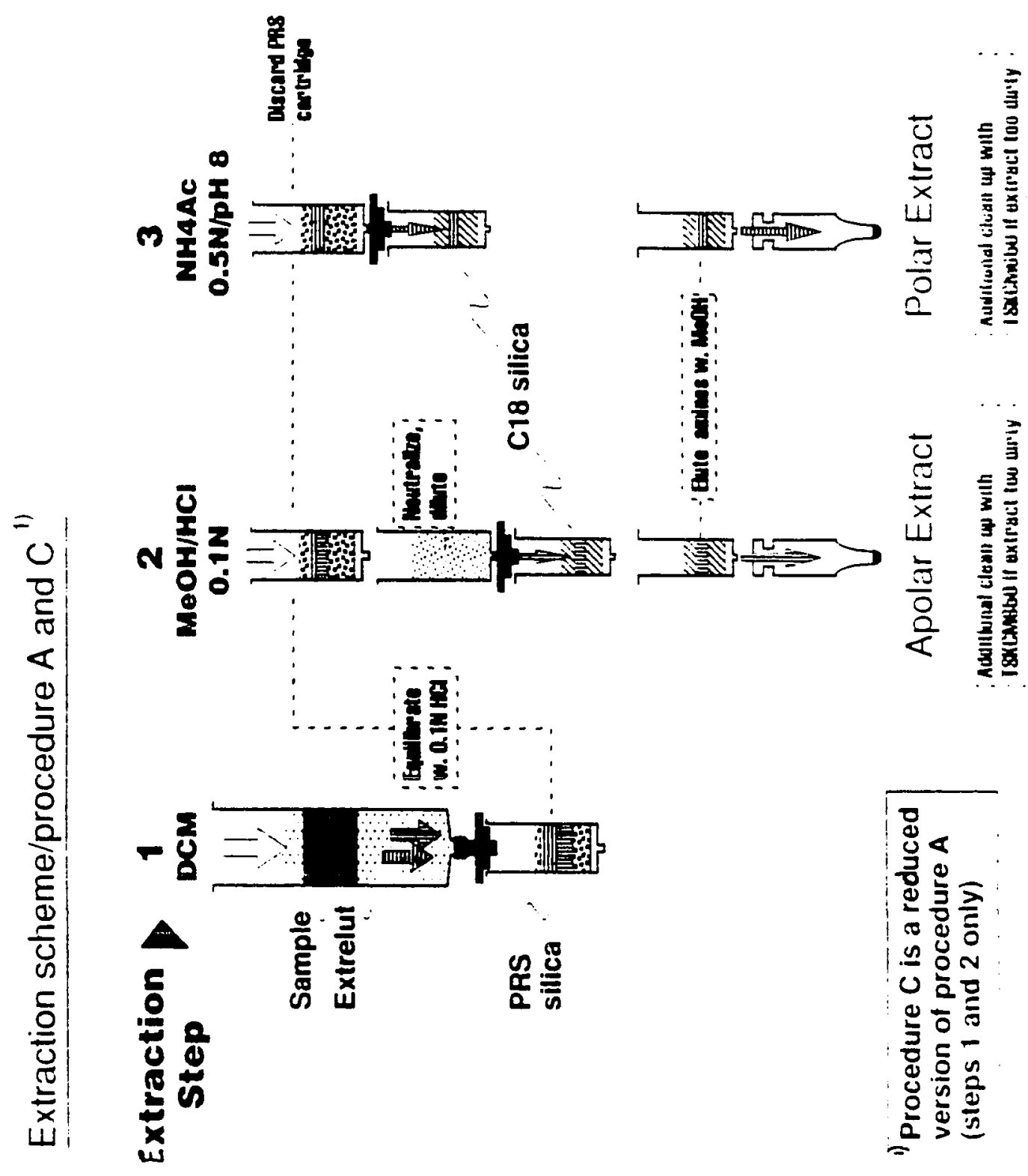


APPENDIX FOUR

AMES TEST PROTOCOL

112 


\section{PLATE INCORPORATION SALMONELLA/AMES TEST}

\section{BACTERIA}

Inoculate bacteria into $30 \mathrm{ml}$ Oxiod nutient broth

Incubate at $37^{\circ} \mathrm{C}$ with shaking for approximatly 16 hours, and refrigerate at $4^{\circ} \mathrm{C}$ untill ready to use on the same day.

\section{TOP AGAR TUBES}

Melt top agar in microwave; cool to about 60 degress $C$ and add $10 \mathrm{ml}$ of $0.5 \mathrm{M}$ L-histidine $\mathrm{HCl} / 0.5 \mathrm{mM}$ biotin solution to $100 \mathrm{ml}$ of the molten agar. Trace of histidine in the top agar allows all bacteria to undergo several divisions and produce a faint background lawn. DNA replication is necessary for mutagenesis to occur. block.

Dispense $2 \mathrm{ml}$ to each tube, and keep aagar in $45^{\circ} \mathrm{C}$ heating S9 MIX

S9 mix is added for compounds that require metabolic activation before mutagenesis can occur.

Volume added to each plate is $0.5 \mathrm{ml}$, and kept on ice at all times. It consists of:

1. Cofactors: NADP $30 \mathrm{mg} / \mathrm{ml}$,glucose-6-phosphate $18 \mathrm{mg} / \mathrm{ml}$, combine dissolve in water and filter. Sterilize through a 0.45 micron filter. Volume needed per plate is $10 \%$ of the total $\mathrm{S} 9 \mathrm{mix}$ (i.e. $0.05 \mathrm{ml}$ )

2. S9 needed per plate is $2 \mathrm{mg}$ (concentration can vary).

3. Buffer needed for S9 mix;

mix $\mathrm{KCl} / \mathrm{Na}$ phosphate buffer and $\mathrm{MgCl}_{2}$ in equal volume.

Volume of the buffer needed for each plate $-0.5 \mathrm{ml}$, volume of $\mathrm{S} 9$, volume of cofactor $=0.05 \mathrm{ml}$. 


\section{AMES ASSAY}

To each agar tube add the following in order:

1. Bacteria (fresh overnight culture with approximatly $1 \times 10^{9}$ bacteria/ $\mathrm{ml}$.

2. Mutagen--up to $0.1 \mathrm{ml}$ (dissolve in DMSO or other suitable solvents).

3. $\mathrm{S} 9 \mathrm{mix}--0.5 \mathrm{ml}$.

Vortex for a few seconds and add immediately to the minimal glucose plates maintained at room temperature. Swirl plate and incubate at $37{ }^{\circ} \mathrm{C}$ for 48 hours.

Bacterial colonies can be scored in immediately upon removal from the incubator or refrigerated and scored later.

\section{CONTROLS}

1. Spontaneous mutation $--0.1 \mathrm{ml}$ of DMSO or other solvents with or without $\mathrm{Sg}$ mix.

2. Sterility of S9.

3. A positive control with a known mutagen. 


\section{APPENDIX FIVE}

ANALYSIS OF VARIANCE STATISTICAL DATA RESULTS AND PLOTS. 
BLOOD 1

Type III Sums of Squares

\begin{tabular}{|c|c|c|c|c|c|}
\hline Source & $d f$ & Sum of Squares & Mean Square & F-Value & P-Value \\
\hline DIET & 1 & .370 & .370 & 1.853 & .2224 \\
\hline DOSE & 1 & 2.112 & 2.112 & 10.576 & .0174 \\
\hline Residual & 6 & 1.198 & .200 & & \\
\hline
\end{tabular}

Dependent: pgm MelQx/gm Tis

Model Coefficient Table

Dependent: pgm MelQx/gm Tis

\begin{tabular}{|c|c|c|c|c|c|}
\hline \multirow{3}{*}{$\begin{array}{l}\text { Intercept } \\
\text { DIET }\end{array}$} & & Beta & Std. Error & $t$-Test & P-Value \\
\hline & & 2.057 & .258 & 7.971 & .0002 \\
\hline & C & -.497 & .365 & -1.361 & .2224 \\
\hline \multirow{3}{*}{ DOSE } & $\mathrm{H}$ & 0.000 & - & • & - \\
\hline & $L$ & -1.187 & .365 & -3.252 & .0174 \\
\hline & $\mathrm{H}$ & 0.000 & - & - & - \\
\hline
\end{tabular}

Interaction Plot

Effect: DOSE

Dependent: pgm MelQx/gm Tis

With Standard Error error bars.

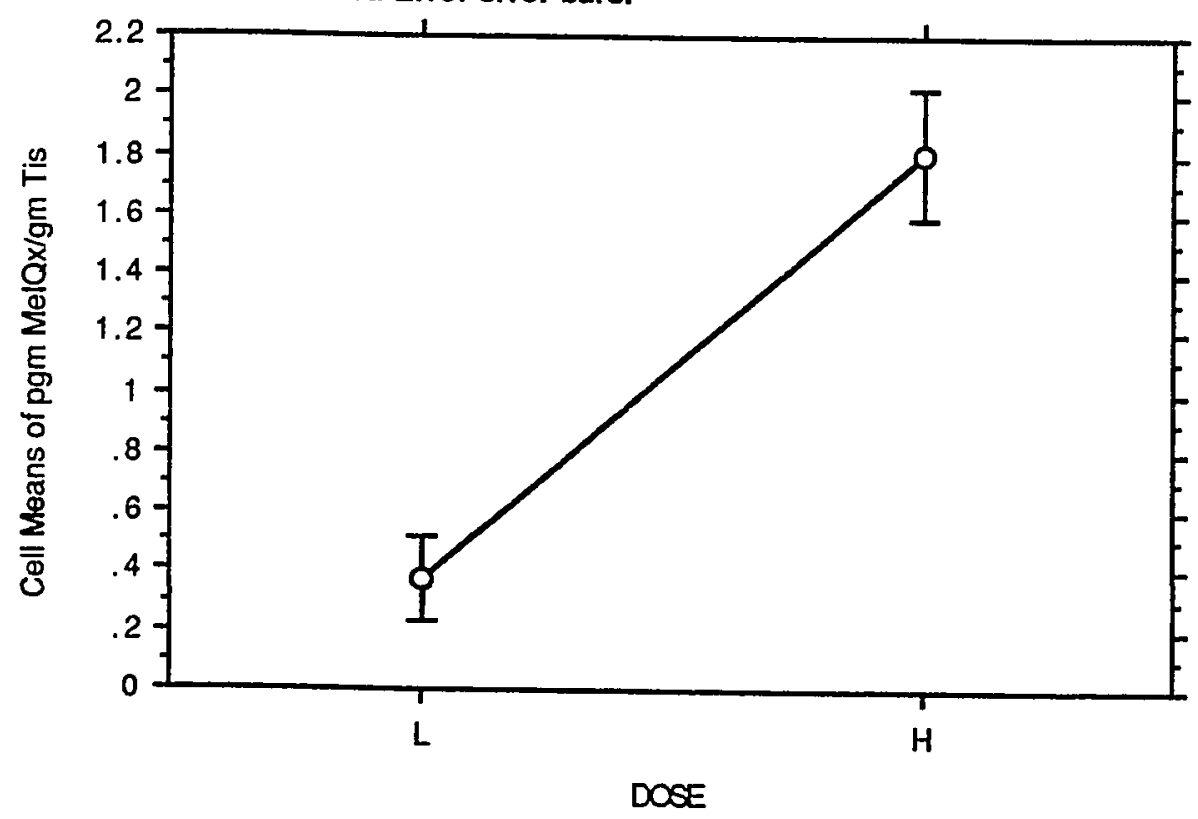




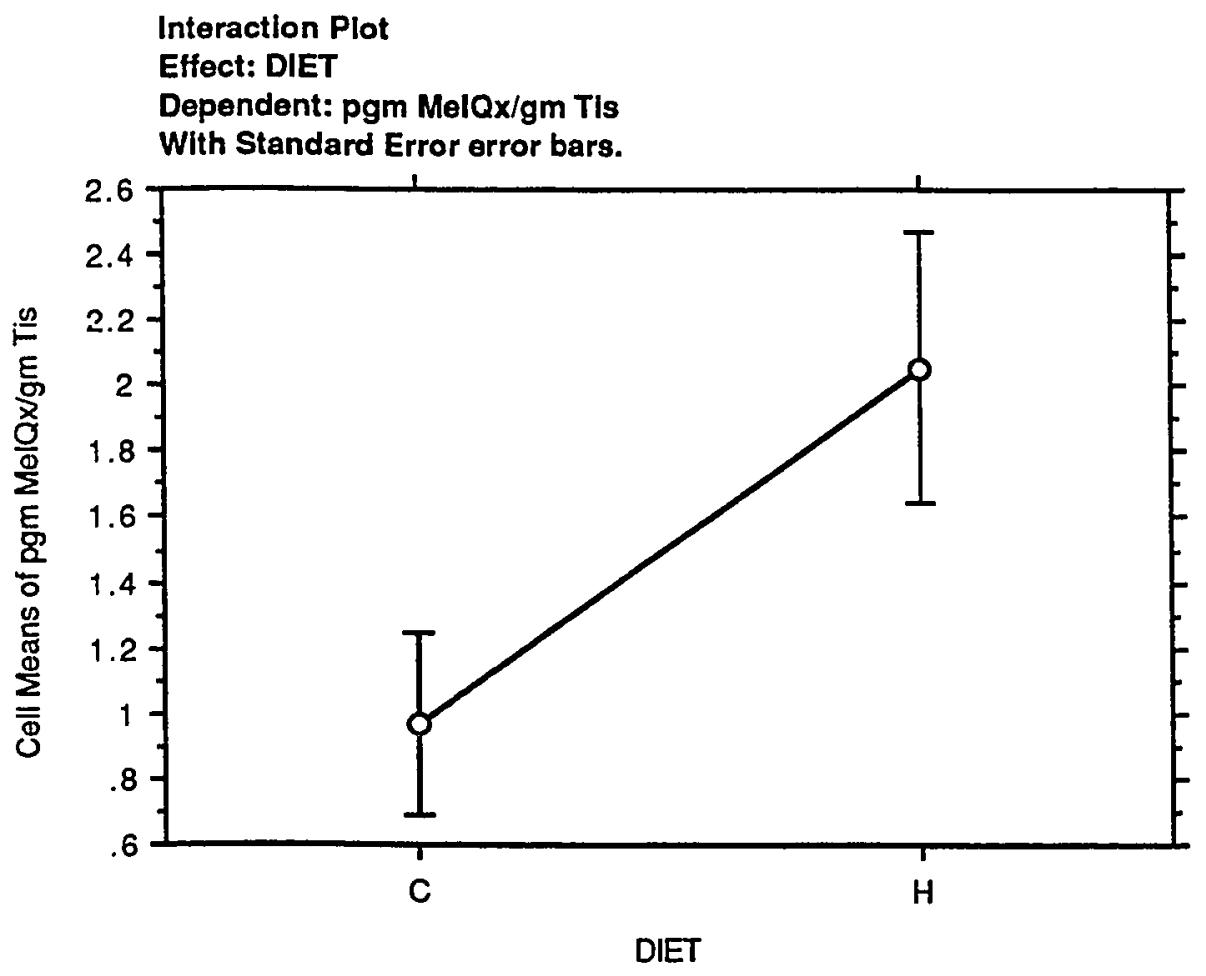


HEART 1

Type III Sums of Squares

Source
\begin{tabular}{|l|r|r|r|r|r|}
\hline DIET & 1 & .132 & .132 & .097 & .7661 \\
\hline DOSE & 1 & 38.760 & 38.760 & 28.462 & .0018 \\
\hline Residual & 6 & 8.171 & 1.362 & & \\
\hline
\end{tabular}

Dependent: pgm MelQx/gm Tis

Model Coefficient Table

Dependent: pgm MelQx/gm Tis

\begin{tabular}{|c|c|c|c|c|c|}
\hline \multirow[b]{2}{*}{ Intercept } & & Beta & Std. Error & $t$-Test & P-Value \\
\hline & & 8.080 & .674 & 11.992 & .0001 \\
\hline \multirow[t]{2}{*}{ DIET } & $\mathrm{C}$ & -.297 & .953 & -.311 & .7661 \\
\hline & $\mathrm{H}$ & 0.000 & - & - & - \\
\hline \multirow[t]{2}{*}{ DOSE } & $L$ & -5.083 & .953 & -5.335 & .0018 \\
\hline & $\mathrm{H}$ & 0.000 & - & - & - \\
\hline
\end{tabular}

Interactlon Plot

Effect: DOSE

Dependent: pgm MelQx/gm Tis

With Standard Error error bars.

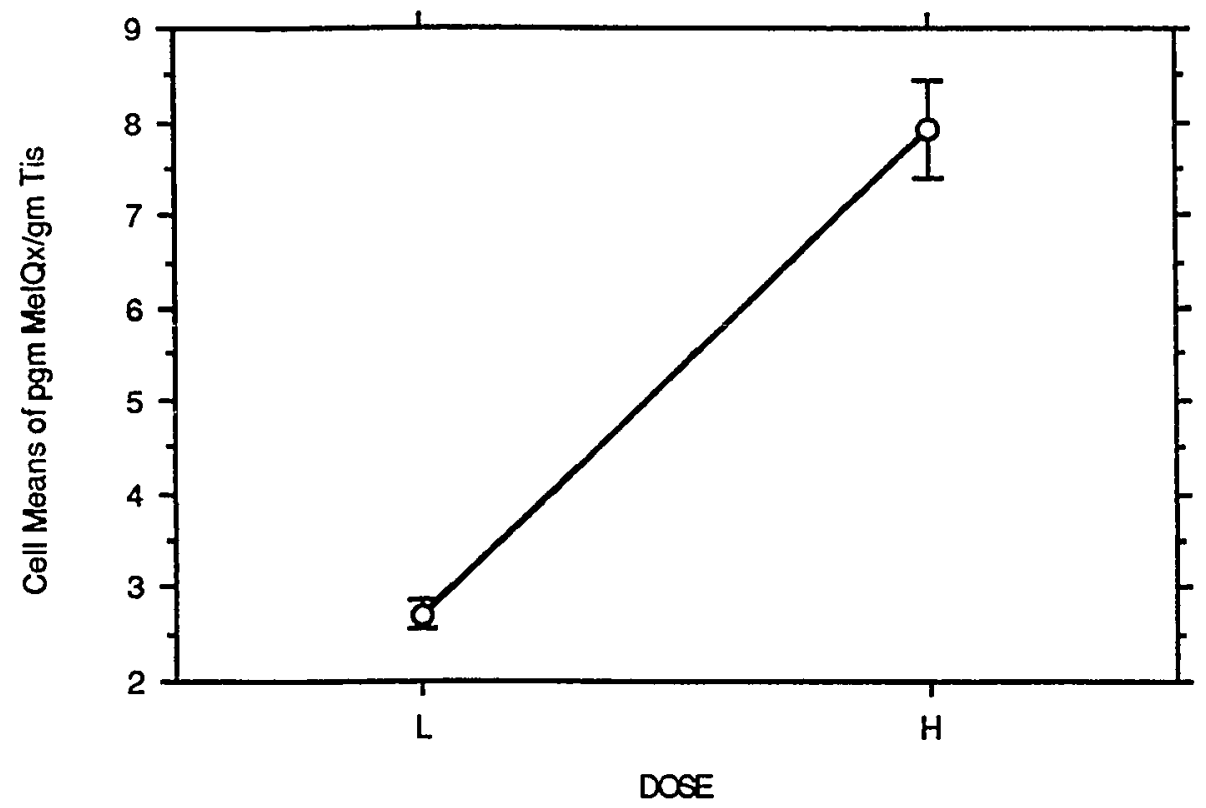




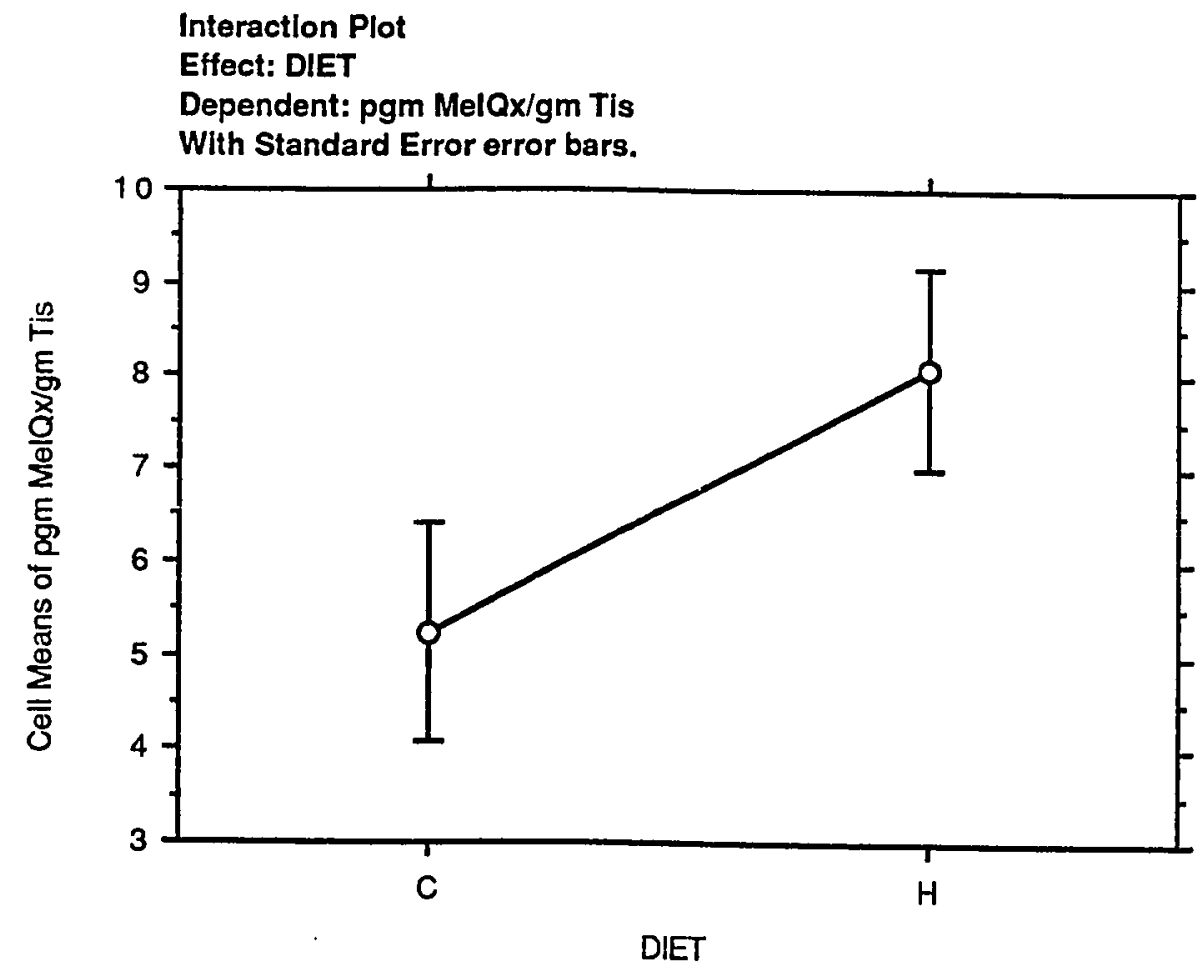


KIDNEY 1

Type III Sums of Squares

\begin{tabular}{|c|c|c|c|c|c|}
\hline Source & $d f$ & Sum of Squares & Mean Square & F-Value & P-Value \\
\hline DIET & 1 & 12.557 & 12.557 & .021 & .8906 \\
\hline DOSE & 1 & 12093.366 & 12093.366 & 19.824 & .0043 \\
\hline Residual & 6 & 3660.141 & 610.023 & & \\
\hline
\end{tabular}

Dependent: pgm MelQx/gm Tis

Model Coefficient Table

Dependent: pgm MelQx/gm Tis

\begin{tabular}{|c|c|c|c|c|c|}
\hline & & Beta & Std. Error & t-Test & P.Value \\
\hline \multirow{3}{*}{$\begin{array}{l}\text { Intercept } \\
\text { DIET }\end{array}$} & & 130.450 & 14.260 & 9.148 & .0001 \\
\hline & $c$ & -2.893 & 20.166 & -.143 & .8906 \\
\hline & $\mathrm{H}$ & 0.000 & $\bullet$ & - & - \\
\hline \multirow[t]{2}{*}{ DOSE } & $L$ & -89.790 & $=0.166$ & -4.452 & .0043 \\
\hline & $\mathrm{H}$ & 0.000 & $\bullet$ & $\bullet$ & - \\
\hline
\end{tabular}

Interaction Plot

Effect: DOSE

Dependent: pgm MelQx/gm Tis

With Standard Error error bars.

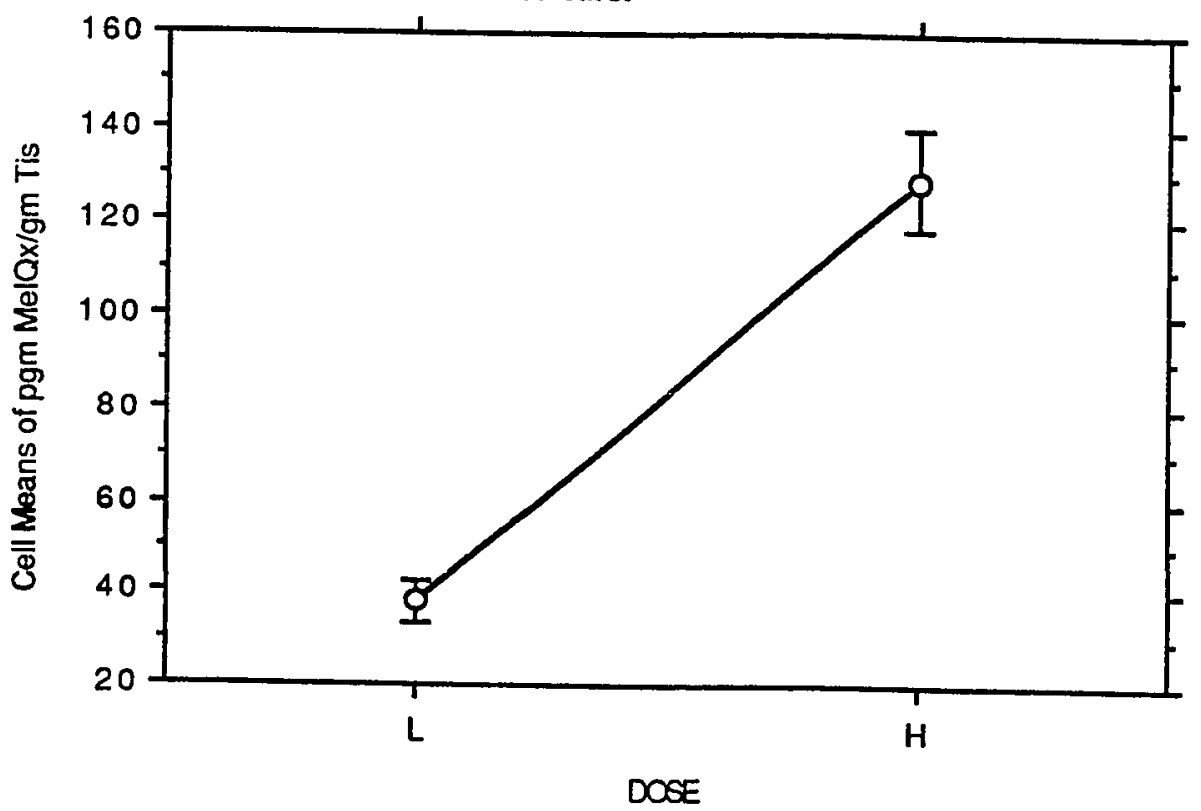




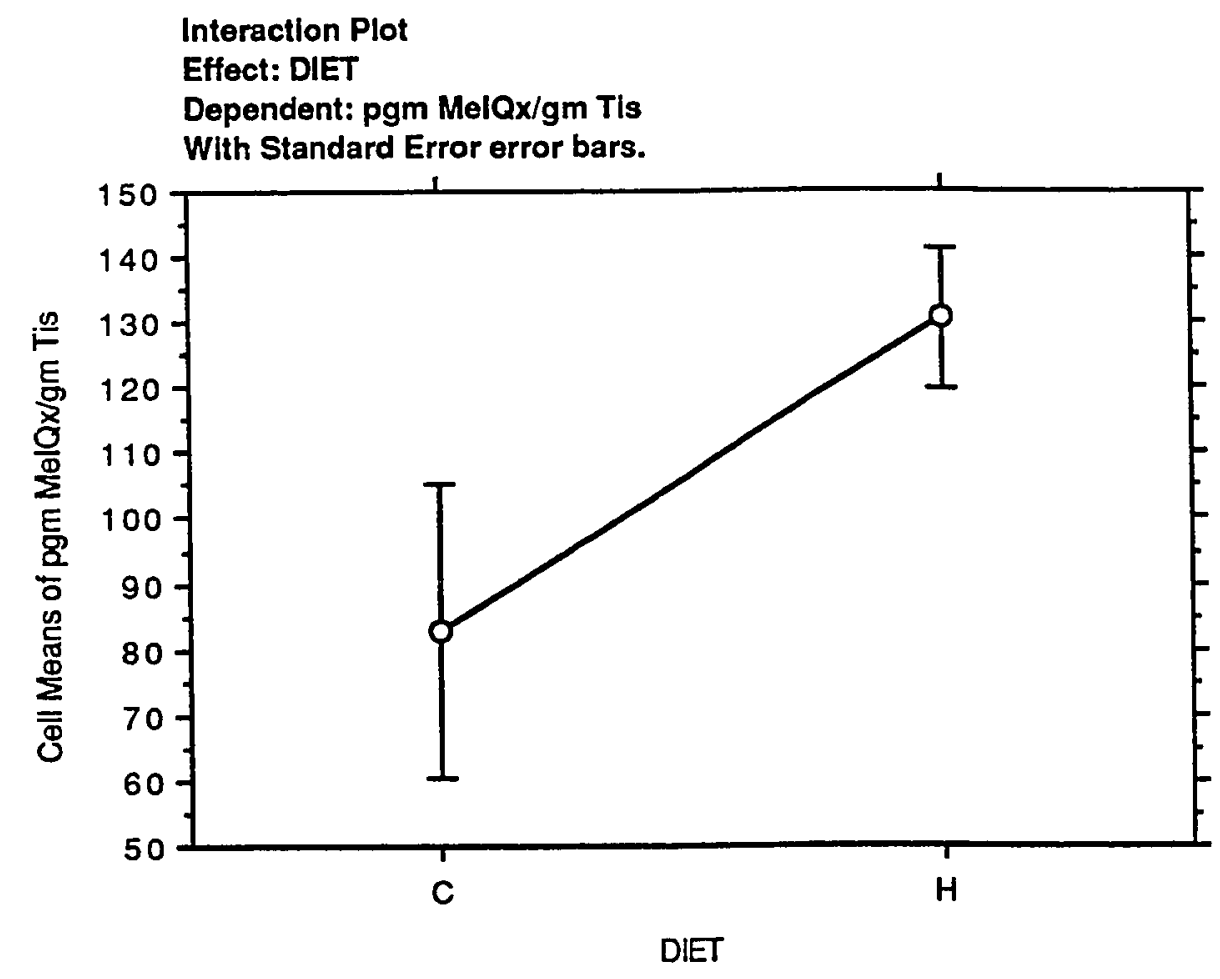


LIVER 1

Type III Sums of Squares

\begin{tabular}{|c|c|c|c|c|c|}
\hline Source & $d f$ & Sum of Squares & Mean Square & F-Value & P-Value \\
\hline DIET & 1 & 2204.167 & 2204.167 & 3.070 & .1303 \\
\hline DOSE & 1 & 12904.771 & 12904.771 & 17.975 & .0054 \\
\hline Residual & 6 & 4307.682 & 717.947 & & \\
\hline
\end{tabular}

Dependent: pgm MelQx/gm Tis

Model Coefficient Table

Dependent: pgm MelQx/gm Tis

\begin{tabular}{|c|c|c|c|c|c|}
\hline \multirow{3}{*}{$\begin{array}{l}\text { Intercept } \\
\text { DIET }\end{array}$} & & Beta & Std. Error & $t$-Test & P-Value \\
\hline & & 99.130 & 15.470 & 6.408 & .0007 \\
\hline & C & 38.333 & 21.878 & 1.752 & .1303 \\
\hline \multirow{3}{*}{ DOSE } & $\mathrm{H}$ & 0.000 & - & - & - \\
\hline & $L$ & -92.753 & 21.878 & -4.240 & .0054 \\
\hline & $\mathrm{H}$ & 0.000 & - & - & - \\
\hline
\end{tabular}

Interaction Plot

Effect: DOSE

Dependent: pgm MelQx/gm Tis

With Standard Error error bars.

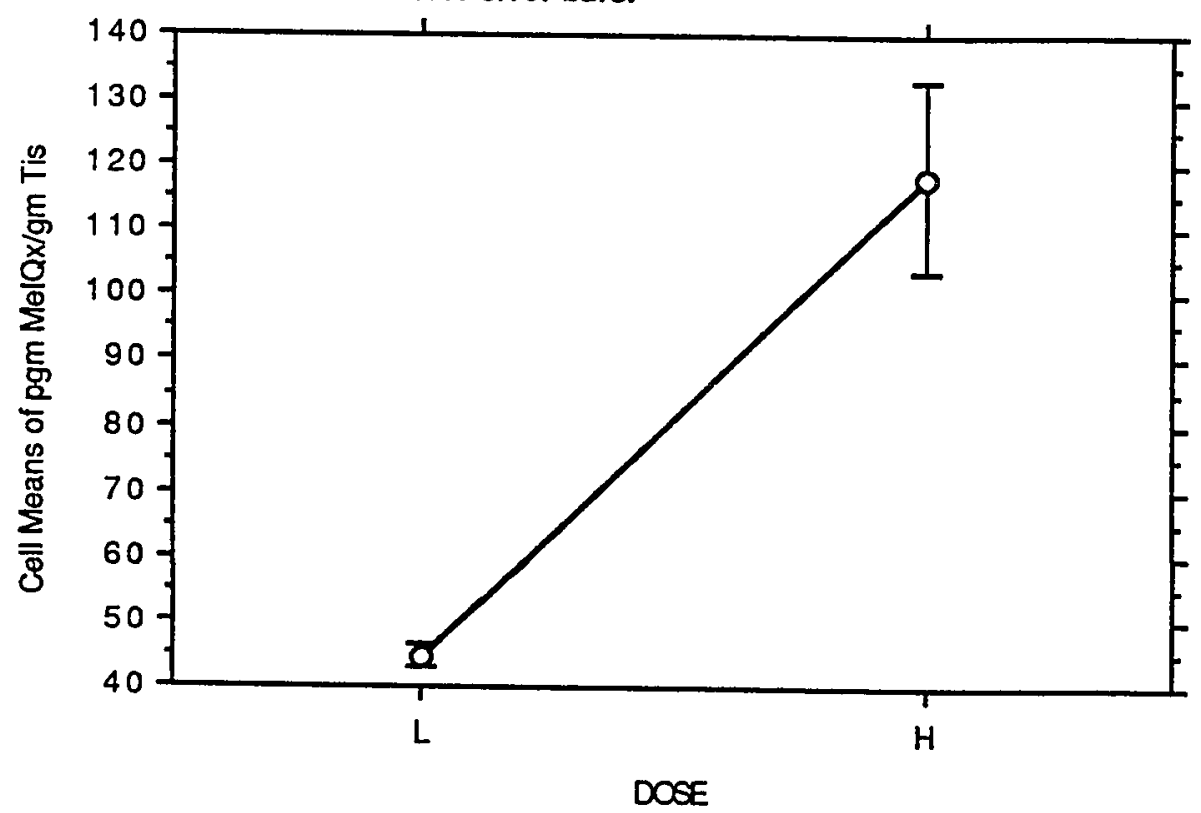




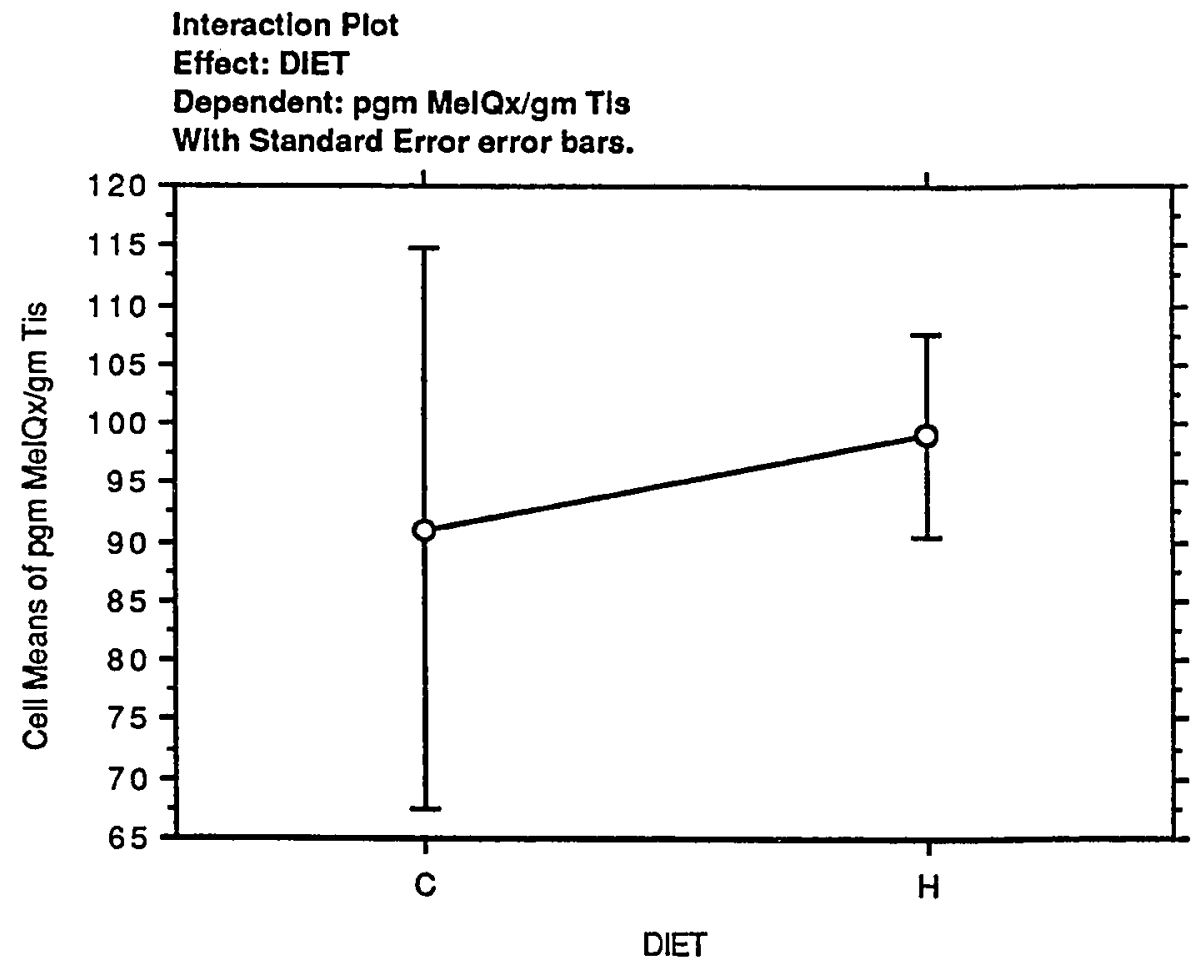


LUNG 1

Type III Sums of Squares

\begin{tabular}{|c|c|c|c|c|c|}
\hline Source & $d f$ & Sum of Squares & Mean Square & F-Value & P-Value \\
\hline DIET & 1 & .019 & .019 & .018 & .8978 \\
\hline DOSE & 1 & 47.040 & 47.040 & 43.809 & .0006 \\
\hline Residual & 6 & 6.442 & 1.074 & & \\
\hline
\end{tabular}

Dependent: pgm MelQx/gm Tis

Model Coefficlent Table

Dependent: pgm MelQx/gm Tis

\begin{tabular}{|c|c|c|c|c|c|}
\hline & & Beta & Std. Error & t-Test & P-Value \\
\hline Intercept & & 7.277 & .598 & 12.163 & .0001 \\
\hline \multirow[t]{2}{*}{ DIET } & $c$ & .113 & .846 & .134 & .8978 \\
\hline & $\mathrm{H}$ & 0.000 & $\cdot$ & $\cdot$ & $\cdot$ \\
\hline \multirow[t]{2}{*}{ DOSE } & $L$ & -5.600 & .846 & -6.619 & .0006 \\
\hline & $\mathrm{H}$ & 0.000 & $\cdot$ & $\bullet$ & • \\
\hline
\end{tabular}

Interaction Plot

Effect: DOSE

Dependent: pgm MelOx/gm Tis

With Standard Error error bars.

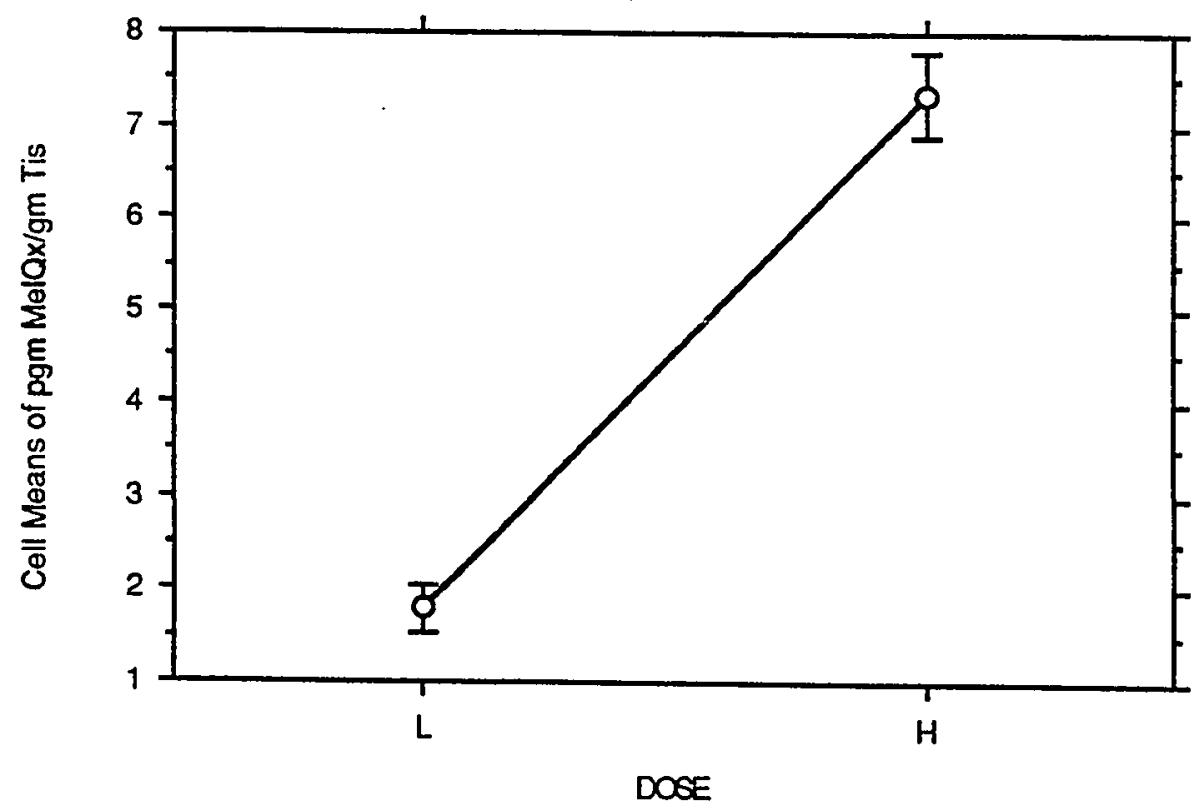




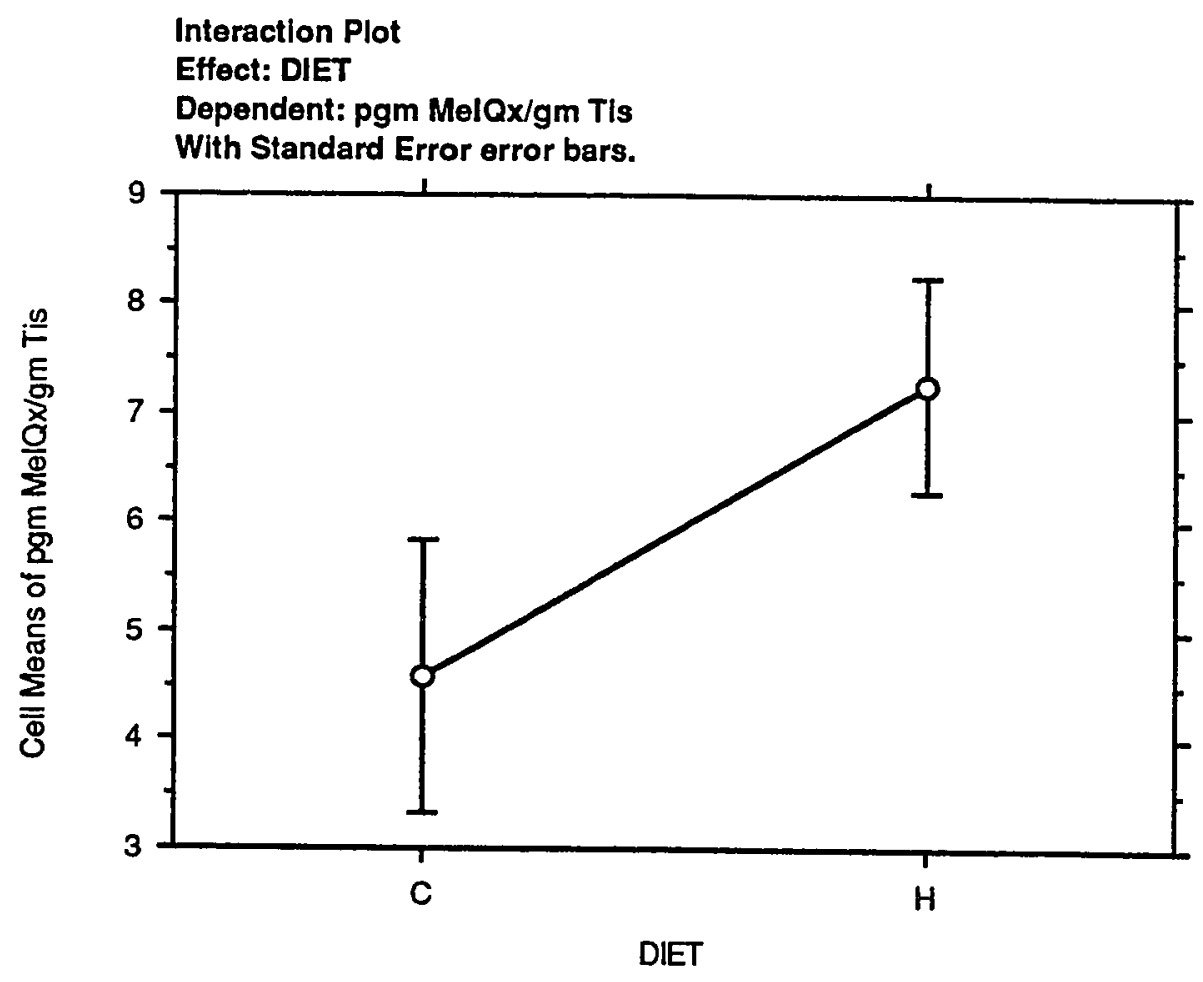




\section{PANCREAS 1}

Type III Sums of Squares

Source
\begin{tabular}{|l|r|r|r|r|r|}
\hline DIET & 1 & 20.907 & 20.907 & 1.331 & .2925 \\
\hline DOSE & 1 & 111.457 & 111.457 & 7.096 & .0373 \\
\hline Residual & 6 & 94.238 & 15.706 & & \\
\hline
\end{tabular}

Dependent: pgm MelQx/gm Tis

Model Coefficient Table

Dependent: pgm MelQx/gm Tis

\begin{tabular}{|c|c|c|c|c|c|}
\hline \multirow[b]{2}{*}{ Intercept } & & Beta & Std. Error & t-Test & P-Value \\
\hline & & 7.503 & 2.288 & 3.279 & .0168 \\
\hline \multirow[t]{2}{*}{ DIET } & $c$ & 3.733 & 3.236 & 1.154 & .2925 \\
\hline & $\mathrm{H}$ & 0.000 & - & - & • \\
\hline \multirow[t]{2}{*}{ DOSE } & $L$ & -8.620 & 3.236 & -2.664 & .0373 \\
\hline & $\mathrm{H}$ & 0.000 & - & - & - \\
\hline
\end{tabular}

Interaction Plot

Effect: DOSE

Dependent: pgm MelQx/gm Tis

With Standard Error error bars.

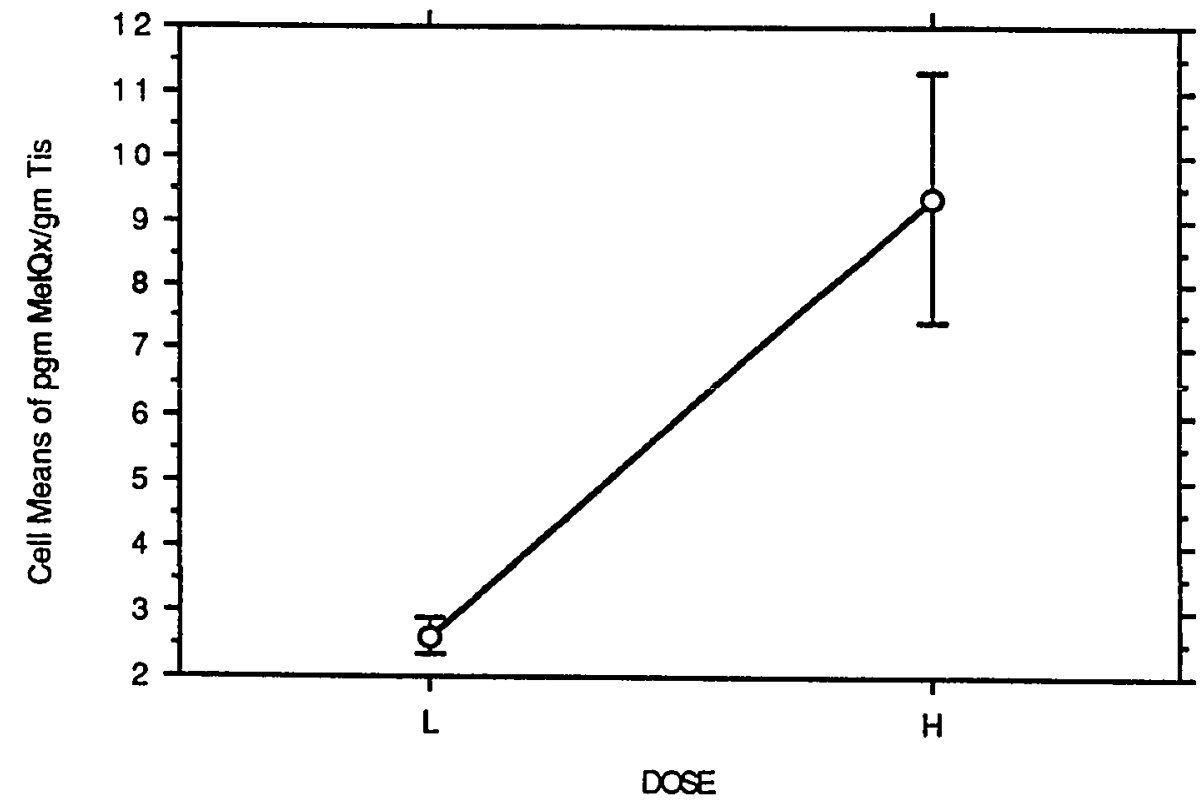




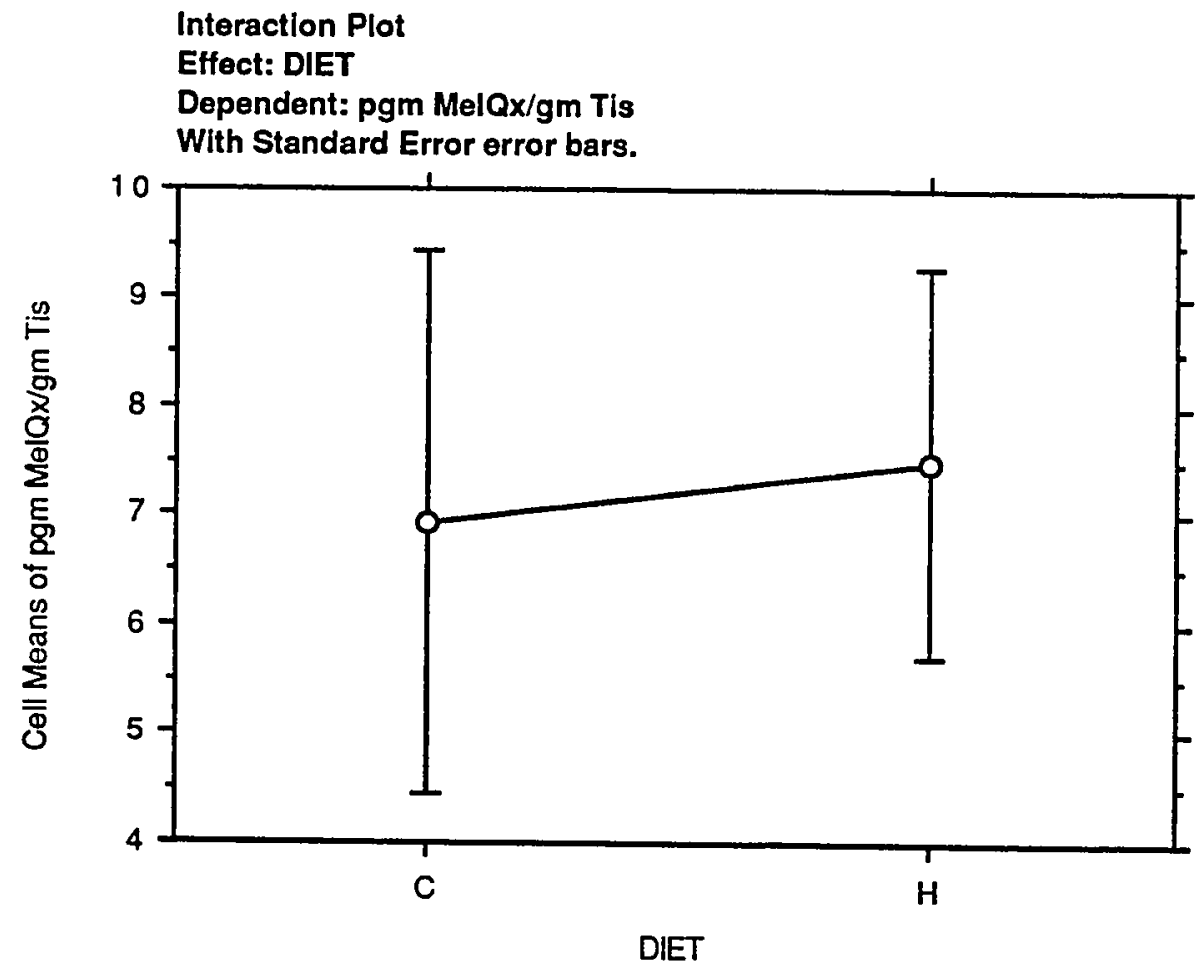


SPLEEN 1

Type III Sums of Squares

\begin{tabular}{|l|r|r|r|r|r|}
\hline Source & \multicolumn{2}{c}{ df } & Sum of Squares & Mean Square & F-Value \\
\hline DlET & 1 & 64.354 & 64.354 & 20.398 & .0040 \\
\hline DOSE & 1 & 258.595 & 258.595 & 81.965 & .0001 \\
\hline Residual & 6 & 18.930 & 3.155 & & \\
\hline
\end{tabular}

Dependent: pgm MelQx/gm Tis

Model Coefficient Table

Dependent: pgm MelQx/gm Tis

\begin{tabular}{|c|c|c|c|c|c|}
\hline & & Beta & Std. Error & $t$-Test & P.Value \\
\hline \multirow{3}{*}{$\begin{array}{l}\text { Intercept } \\
\text { DIET }\end{array}$} & & 9.620 & 1.025 & 9.381 & .0001 \\
\hline & $C$ & 6.550 & 1.450 & 4.516 & .0040 \\
\hline & $\mathrm{H}$ & 0.000 & - & - & - \\
\hline \multirow[t]{2}{*}{ DOSE } & $L$ & -13.130 & 1.450 & -9.053 & .0001 \\
\hline & $\mathrm{H}$ & 0.000 & - & - & - \\
\hline
\end{tabular}

Interaction Plot

Effect: DOSE

Dependent: pgm MelQx/gm Tis

With Standard Error error bars.

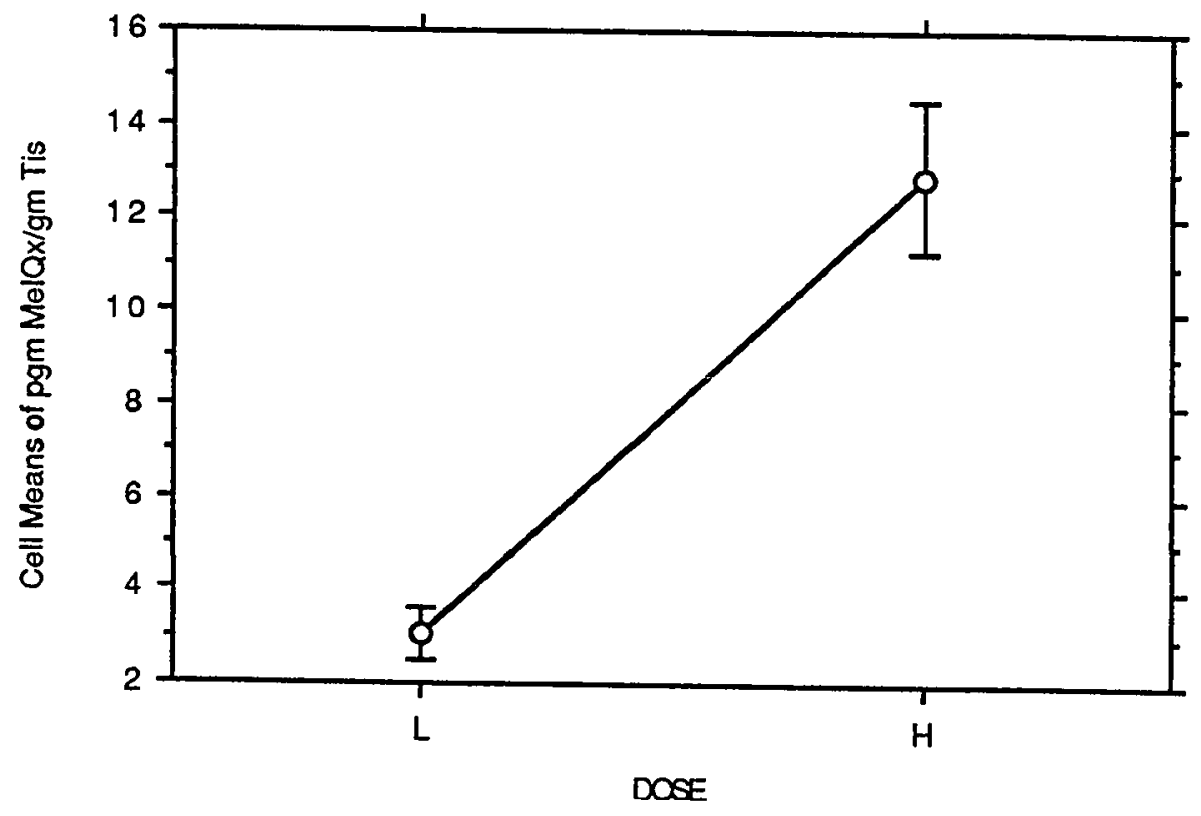




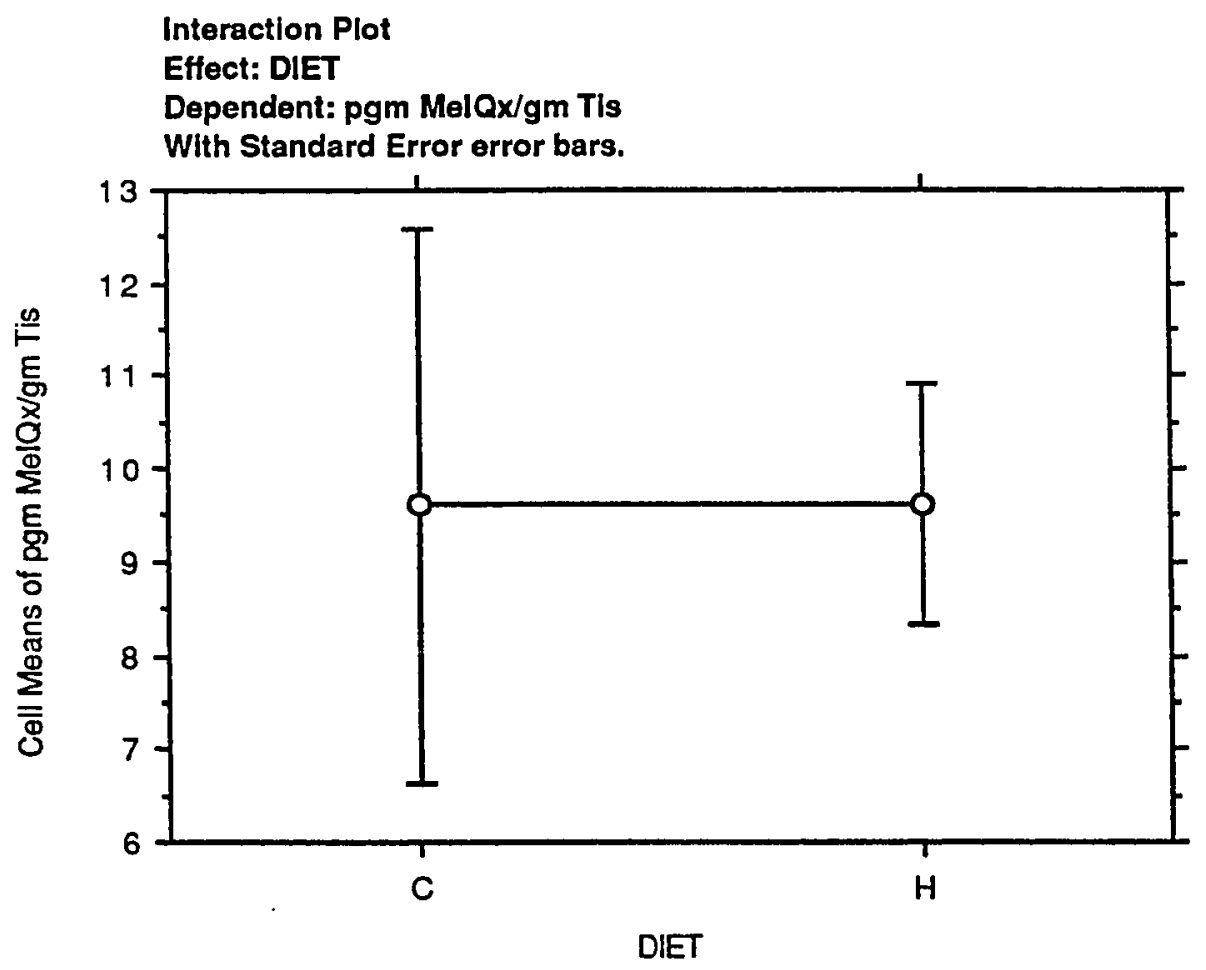


THYMUS 1

Type III Sums of Squares

\begin{tabular}{l} 
Source \\
\begin{tabular}{|l|r|r|r|r|r|}
\hline DIET & df & Sum of Squares & Mean Square & F-Value & P-Value \\
\hline DOSE & 1 & 1.961 & 1.961 & .959 & .3653 \\
\hline Residual & 1 & 19.838 & 19.838 & 9.700 & .0207 \\
\hline
\end{tabular} \\
\hline
\end{tabular}

Dependent: pgm MelQx/gm Tis

Model Coefficient Table

Dependent: pgm MelQx/gm Tis

\begin{tabular}{|c|c|c|c|c|c|}
\hline & & Beta & Std. Error & t-Test & P-Value \\
\hline \multirow{3}{*}{$\begin{array}{l}\text { Intercept } \\
\text { DIET }\end{array}$} & & 6.650 & .826 & 8.054 & .0002 \\
\hline & C & -1.143 & 1.168 & -.979 & .3653 \\
\hline & $\mathrm{H}$ & 0.000 & - & - & - \\
\hline \multirow[t]{2}{*}{ DOSE } & $L$ & -3.637 & 1.168 & -3.114 & .0207 \\
\hline & $\mathrm{H}$ & 0.000 & - & • & - \\
\hline
\end{tabular}

Interaction Plot

Effect: DOSE

Dependent: pgm MelQx/gm Tis

With Standard Error error bars.

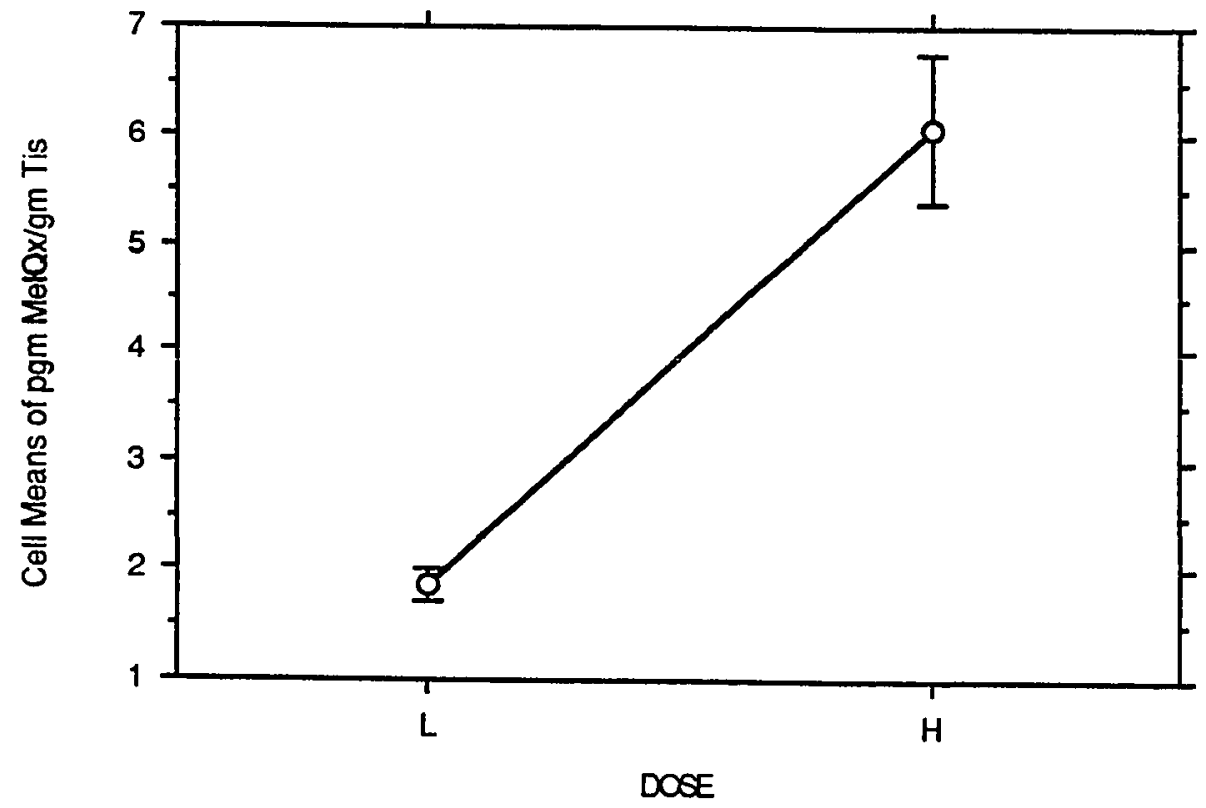




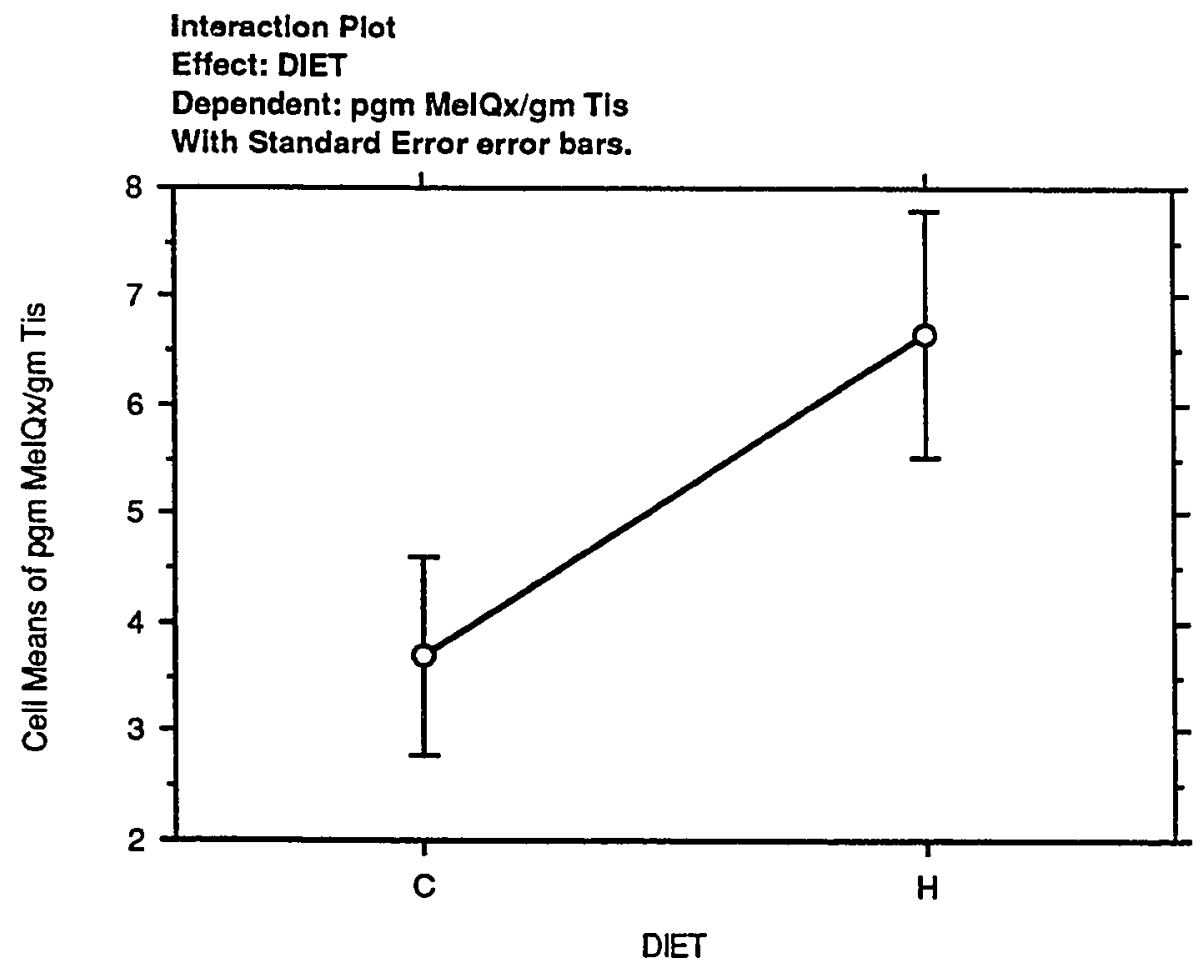

